Aquatic Plant Control Research Program

\title{
A Simulation Model for Growth of the Submersed Aquatic Macrophyte Sago Pondweed (Potamogeton pectinatus L.)
}

Elly P. H. Best and William A. Boyd July 2003 


\section{A Simulation Model for Growth of the Submersed Aquatic Macrophyte Sago Pondweed (Potamogeton pectinatus L.)}

Elly P. H. Best and William A. Boyd

Environmental Laboratory

U.S. Army Engineer Research and Development Center 3909 Halls Ferry Road

Vicksburg, MS 39180-6199

Final report

Approved for public release; distribution is unlimited

Prepared for U.S. Army Corps of Engineers

Washington, DC 20314-1000

Under Work Unit 33128 
ABSTRACT: A simulation model for biomass dynamics of the submersed macrophyte Potamogeton pectinatus L. is presented. The model (POTAM) is based on carbon flow through the vegetation in meter-squared $\left(\mathrm{m}^{2}\right)$ water columns. It includes descriptions of several factors that affect biomass dynamics, such as site characteristic changes in climate, temperature, water transparency, water level, $\mathrm{pH}$, and oxygen effects on $\mathrm{CO}_{2}$ assimilation rate at light saturation, wintering strategies, mechanical control (removal of shoot biomass), and grazing. The characteristics of community and site can be easily modified by the user.

POTAM incorporates insight into the processes affecting the dynamics of a sago pondweed community in relatively shallow, hard water (0.1- to 6-m depth; dissolved inorganic carbon concentration $>0.8 \mathrm{mmol}$ and $\mathrm{pH}>6$ ), under ample supply of nitrogen and phosphorus in a pest-, disease-, and competitor-free environment under the prevailing weather conditions. It has been calibrated on data pertaining to a sago pondweed community in the Western Canal near Zandvoort, The Netherlands. At this site, growth starts from the subterranean tubers alone. Plant biomass usually peaks once a year, in July, and intensive downward transport of soluble carbohydrates occurs after anthesis, used for the formation of tubers that grow into the sediment.

POTAM simulated the dynamics of plant and tuber biomass and tuber numbers in the Western Canal near Zandvoort, The Netherlands, well over a period of 1 to 5 years. Starting from measured instead of nominal tuber size increased the similarity between simulated and measured plant data. The importance of several plant speciescharacteristic properties was explored, namely, of leaf surface:dry weight ratio, tuber bank density, anchorage depth, and presence/absence of wintering shoots.

The model has been used to calculate plant and tuber biomass and tuber numbers for other sites as well. In Lake Veluwe, The Netherlands, a site with a temperate climate, simulated plant biomass and newly produced tuber densities were similar to measured ones in two consecutive years, but timing in the simulated plants was delayed the second year. In the Byrnes Canal, California, with a far warmer temperate climate, simulated plant biomass and tuber bank density were similar to measured values when a lower self-shading coefficient than the nominal one and the same tuber size/tuber number per plant as measured were used. However, plant biomass and tuber bank density were lower with the nominal self-shading coefficient. In the tropical Lake Ramgarh, India, a simulated peak plant biomass similar to measured was found using the same lower self-shading coefficient as run for the California site, and almost no tubers were formed. Verification of simulated with measured tuber numbers was not possible, since tubers had not been measured.

Several case studies are presented in which POTAM generated insight useful for management aimed at conserving or controlling sago pondweed populations. The model was used to calculate the tentative effects on sago pondweed populations of (a) water level fluctuations, including floods and droughts, in the Upper Mississippi River; and (b) plant and tuber mass removal by cutting or grazing.

Sensitivity analysis showed that maximum plant biomass is most sensitive to a change in photosynthetic activity at light saturation but not to a change in light use efficiency. Maximum plant biomass was also strongly affected by changes in pre-anthesis development rate. End-of-year tuber number was sensitive to 7 out of the 9 parameters tested. Sensitivity was greatest to changes in pre-anthesis development rate.

Effects of changes in environmental factors were analyzed by applying the same method as used for sensitivity analysis. Maximum plant biomass and end-of-year tuber number proved to be sensitive to changes in climate.

The model can be used as a tool to predict the dynamics of a sago pondweed community over 1- to 5-year periods. Running the model with different parameter values specific for any particular site and/or treatment helps in gaining insight into the predominant mechanisms regulating submersed plant dynamics.

DISCLAIMER: The contents of this report are not to be used for advertising, publication, or promotional purposes. Citation of trade names does not constitute an official endorsement or approval of the use of such commercial products. All product names and trademarks cited are the property of their respective owners. The findings of this report are not to be construed as an official Department of the Army position unless so designated by other authorized documents.

DESTROY THIS REPORT WHEN IT IS NO LONGER NEEDED. DO NOT RETURN TO THE ORIGINATOR. 


\section{Contents}

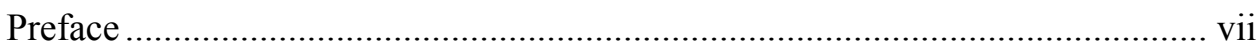

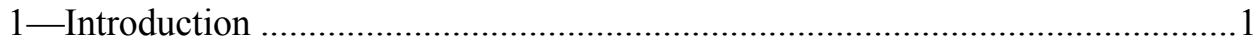

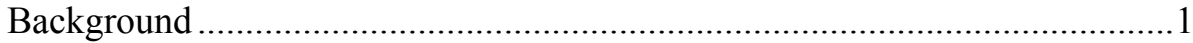

Taxonomy and Distribution of Sago Pondweed within the United

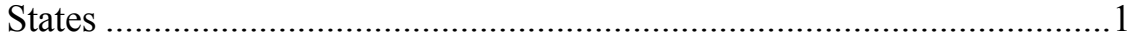

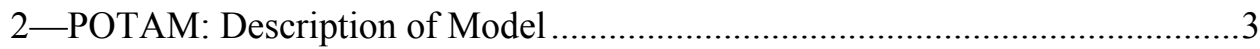

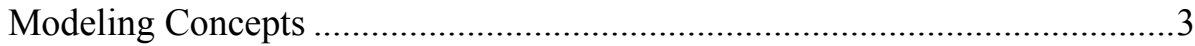

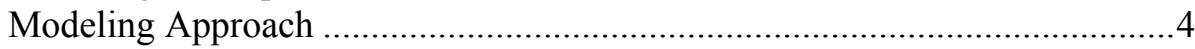

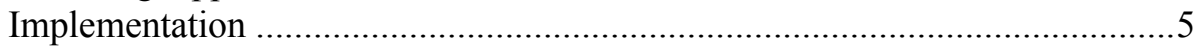

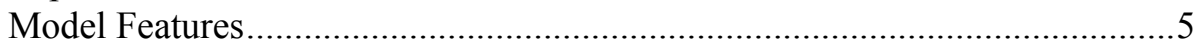

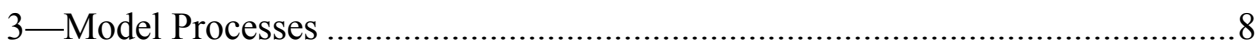

Morphology, Phenological Cycle, and Development ................................... 8

Morphology and phenological cycle of sago pondweed ...........................8

Description of development and phenological cycle in POTAM...............9

Maximum Biomass and Plant Density .................................................... 12

Wintering and Sprouting of Tuber Bank ......................................................13

Initial Growth of Sprouts........................................................................ 16

Light, Photosynthesis, Maintenance, Growth, and Assimilate

Partitioning in Sago Pondweed Plants ..................................................... 19

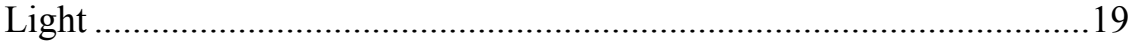

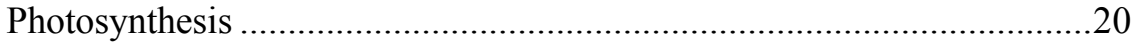

Maintenance, growth, and assimilate partitioning..................................21

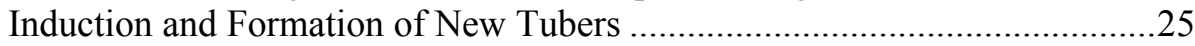

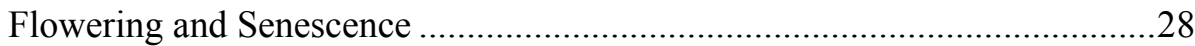

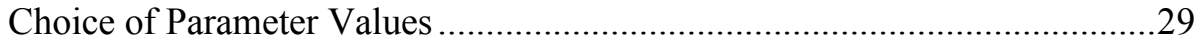

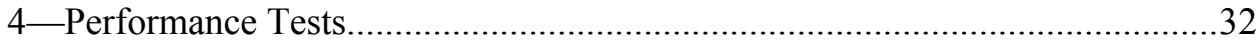

Simulated and Measured Behavior of a Sago Pondweed Community in the Western Canal near Zandvoort, The Netherlands ...........................32

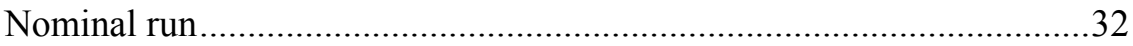

Effects of differences in leaf surface: dry weight ratio..............................34

Effects of differences in tuber bank density and anchorage depth............35

Simulated and Measured Behavior of a Sago Pondweed Community

in Lake Veluwe, The Netherlands, in Two Consecutive Years

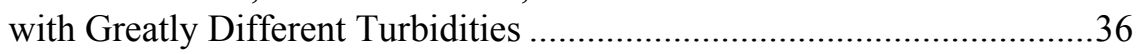


Simulated and Measured Behavior of a Sago Pondweed Community at Other Latitudes

Historical and Simulated Behavior of a Sago Pondweed Community in a Riverine Environment Subject to Flooding.

Simulated Behavior of a Sago Pondweed Community Subject to Biomass Removal; Effects of Cutting and Grazing ...............................46

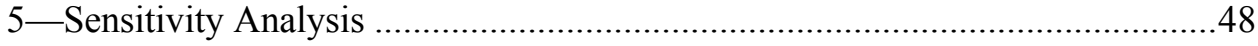

6-Environmental Factor Analysis...............................................................51

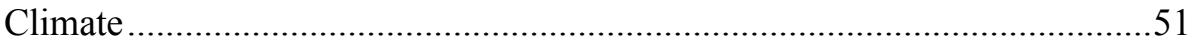

Light Reflection Coefficient by Water Surface …......................................51

Light Extinction Coefficient of Water Column ..........................................52

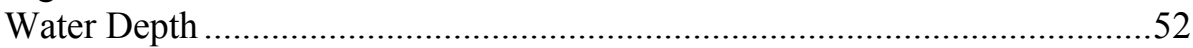

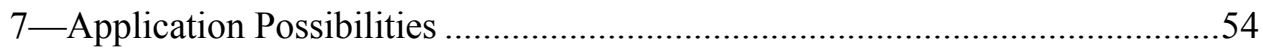

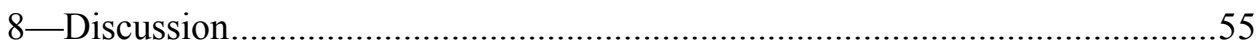

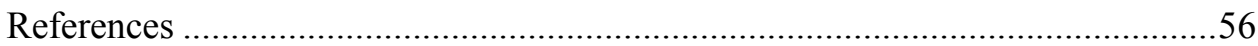

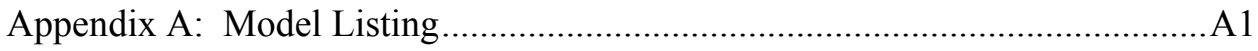

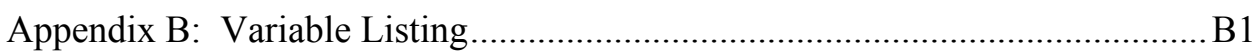

Appendix C: Manipulation of Literature Data Used for the Model

Equations...

SF 298

\section{List of Figures}

Figure 1. Relational diagram illustrating the organization of the model POTAM and its subroutines in combination with the FSE shell..... 6

Figure 2. Relational diagram illustrating the wintering and sprouting of tubers in sago pondweed

Figure 3. Relational diagram illustrating photosynthesis, respiration, and biomass formation in sago pondweed

Figure 4. The relationship between tuber number concurrently initiated per plant and tuber size for sago pondweed

Figure 5. Relational diagram illlustrating translocation and senescence following anthesis in sago pondweed

Figure 6. Simulated biomass of plants, dormant and new tuber numbers, and measured plant biomass of a sago pondweed community in the Western Canal near Zandvoort, The Netherlands 
Figure 7. Simulated behavior of carbohydrate flow through plant compartments of a sago pondweed community in the Western Canal near Zandvoort, The Netherlands

Figure 8. Simulated rates of daily net assimilation and maintenance respiration of a sago pondweed community in the Western Canal near Zandvoort, The Netherlands

Figure 9. Simulated photosynthetic rates of a sago pondweed community in the Western Canal near Zandvoort, The Netherlands, with water or air temperatures as input.

Figure 10. Simulated biomass of plants and tubers of a sago pondweed community in the Western Canal near Zandvoort, The Netherlands, started from different initial biomass conditions, but run in the same environmental and climatological nominal conditions

Figure 11. Simulated biomass of plants and tubers of a sago pondweed community in the Western Canal near Zandvoort, The Netherlands, started from identical nominal initial biomass conditions, except for the Kvalue

Figure 12. Simulated biomass of plants and dormant tubers of a sago pondweed community in the Western Canal near Zandvoort, The Netherlands, started from nominal initial biomass data differing in tuber bank density and anchorage depth

Figure 13. Simulated and measured biomass of plants and tubers of sago pondweed in Lake Veluwe, The Netherlands, during two successive years differing in water transparency.

Figure 14. Simulated biomass of plants and tubers of a sago pondweed community at sites differing in latitude

Figure 15. Developmental stage and Julian day number at which tuber formation is initiated in a sago pondweed community at sites differing in latitude, in relation to day length and temperature

Figure 16. Water level fluctuations over a 10-year period measured at the dam of Pool 8 of the Upper Mississippi River, Wisconsin

Figure 17. Comparison of simulated data on biomass of plants and tubers of sago pondweed in the Upper Mississippi River. 


\section{List of Tables}

Table 1. Relationship between DVS of Sago Pondweed, Day of Year, and $3^{\circ} \mathrm{C}$ Day-Degree Sum in a Temperate Climate ...........12

Table 2. $\quad$ Parameter Values Used in POTAM...........................................30

Table 3. Effects of Cutting Date and Depth on Maximum Shoot Biomass and End-of-year Tuber Number .................................46

Table 4. Relative Sensitivity of Two Model Variables to Deviations in Parameter Values from Their Nominal Values as Presented in Table 2

Table 5. Environmental Factor Analysis, Expressed as Relative Sensitivity of Two Model Variables to Deviations in Parameter Values from Their Nominal Values as Presented in Table 2 


\section{Preface}

The work reported herein was conducted as part of the Aquatic Plant Control Research Program (APCRP) and the Upper Mississippi River - Illinois Waterway (UMR-IWW) System Navigation Study. The APCRP is sponsored by

Headquarters, U.S. Army Corps of Engineers (HQUSACE), and is assigned to the U.S. Army Engineer Research and Development Center (ERDC) under the purview of the Environmental Laboratory (EL), Vicksburg, MS. The UMR-IWW System Navigation Study is being conducted by the U.S. Army Engineer Districts of Rock Island, St. Louis, and St. Paul under the authority of Section 216 of the Flood Control Act of 1970. This study was conducted under Work Unit 33128, "Effects of Macrophytes on Sediment Resuspension." Funding for the APCRP was provided under Department of Army Appropriation Number 96X3122, Construction General. Mr. Robert C. Gunkel, Jr., was Program Manager, APCRP. Technical Monitor during this study was Mr. Timothy Toplisek, HQUSACE.

The work described herein was performed by Dr. Elly P. H. Best, Environmental Risk Assessment Branch (ERAB), Environmental Processes and Engineering Division (EPED), EL, with programming assistance from Mr. William A. Boyd, Environmental Processes Branch (EPB), EPED. Ms. Anne B. Stewart, Dyntel Corporation, assisted with the graphics. Dr. Best and Mr. Boyd prepared this report. Dr. David Spencer, U.S. Department of Agriculture-Agricultural Research Service, Weed Science Program, University of California, Davis, CA, provided an external technical review. The report was reviewed internally by Mr. William F. James, Eau Galle Aquatic Ecosystem Research Facility, Eau Galle, WI, EPB, and Dr. Gregory A. Kiker, ERAB.

This investigation was performed under the direct supervision of Mr. Lance D. Hansen, Chief, ERAB, and the general supervision of Dr. Richard E. Price, Chief, EPED, and Dr. Edwin A. Theriot, Director, EL.

Commander and Executive Director of ERDC was COL John W. Morris III, EN. Director was Dr. James R. Houston.

The contents of this report are not to be used for advertising, publication, or promotional purposes. Citation of trade names does not constitute an official endorsement or approval of the use of such commercial products. 


\section{Introduction}

\section{Background}

The extent to which aquatic macrophytes influence the ecosystem is proportional to plant mass and depends on plant species and physicochemical factors. Therefore, predictions of the environmental impact of management measures on aquatic plant communities should be based on accurate estimates of (a) plant species, mass, and pertinent physiological properties, (b) the contribution of the plant to the various food chains, and (c) the contribution of the decay of the plant to biogeochemical cycling and oxygen regime. A simulation model that simulates metabolism and growth of a specific aquatic macrophyte community may serve as a useful tool in this respect.

Although the number of simulation models for growth of monotypic, submersed macrophyte communities is increasing (e.g., Titus et al. 1975; Best 1981; Collins and Wlosinski 1985; Best and Jacobs 1990; Hootsmans 1991; Scheffer et al. 1993; Best and Boyd 1996, 1999, 2001), it is still relatively low compared to that for terrestrial vegetation. The current model has been developed because none of the existing models was suitable to simulate the behavior of a monotypic sago pondweed community under various environmental and climatological conditions over a period ranging from one season to several years.

\section{Taxonomy and Distribution of Sago Pondweed within the United States}

The submersed, rooted aquatic macrophyte sago pondweed or Stukenia pectinata belongs to the monocotyledonous family of Stukeniaceae. This species has recently moved from the Potamogetonaceae (Voss 1972; Godfrey and Wooten 1997) into the Stukeniaceae (Crow and Hellquist 2000). This report uses the taxonomic name commonly cited up to 2000 , since all literature pertains to the formerly used name of Potamogeton pectinatus for this plant. The name Potamogeton is derived from the Greek word for "river neighbor," and the epithet pectinatus, "comb-like," is derived from the closely set insertion of the frequently branched stem and narrow filiform leaves of the plant, which give it a bushy appearance. The following synonyms have been used in North America: $P$. interruptus Kit, $P$. latifolius J. Robbins, $P$. flabellatus Bab., and $P$. columbianus Suksdorf. Many other synonyms have been used in Europe. Earlier the genus was 
considered as a part of the families of the Zosteraceae and Najadaceae (Fernald 1950). Forty Potamogeton species have been documented relatively recently in North America by Kartesz and Kartesz (1980), and 35 Potamogeton species by the U.S. Department of Agriculture (1982). Approximately 100 Potamogeton species have been identified worldwide (Kadono 1982). P. pectinatus has an average of $2 \mathrm{n}=78$ chromosomes (Kalkman and Van Wijk 1984). It is genetically heterogeneous (Hettiararchi and Triest 1986; Van Wijk et al. 1988) and hybridizes with Potamogeton filiformis and P. vaginatus (Hagstrom 1916; Dandy and Taylor 1946; Harrison 1949). Differences in morphology and ecological characteristics have been linked to annual and perennial P. pectinatus ecotypes (Van Wijk 1983). Two varieties have been associated with differences in water quality: the variety scoparius with bicarbonate-poor waters and the variety interruptus with sewagepolluted waters (Wiegleb 1978).

Sago pondweed occurs in fresh alkaline to slightly saline water (Den Hartog 1981) with a high alkalinity and $\mathrm{pH}>6$ (Lohammar 1938; Spence and Maberly 1984), at depths of 0.1 to $7 \mathrm{~m}$, and rooted in sediment types varying from bedrock to mineral bottoms with particles sizes ranging from rubble to fine clay (Wong and Clark 1976; Pip 1987). In contemporary floras (Fernald 1950; Gleason 1968), P. pectinatus is cited in the American continent from Quebec and Newfoundland to Alaska, in the eastern half of the United States, southwestward to Arizona, and southward to South America. It is native to the western United States and was probably introduced into Florida. Its occurrence has been documented also in Western Europe (Van Wijk 1988), the Russian Federation (Lapirov and Petukhova 1985), and in subtropical and tropical areas, such as India (Sahai and Sinha 1973). It is sometimes considered a nuisance plant in areas with a warm climate, where by virtue of its prolific growth and reproduction, it may interfere with human utilization of freshwater resources, become aesthetically displeasing, or displace desirable indigenous vegetation. However, data on total biomass and productivity indicate that they are small compared with those of several terrestrial plant communities (Spencer and Bowes 1990). This apparent anomaly may be due largely to the uneven distribution of biomass over the water column, with typically $>60$ percent concentrated in the upper water layers (canopy formation). The tubers and seeds have been planted in many localities to improve habitat for ducks. The entire plant is relished by waterfowl. It also provides good habitat for fish. These plantings probably have extended the distribution of this plant beyond its natural range (Martin et al. 1951). A comprehensive review of English literature on P. pectinatus has been published by Kantrud (1990).

The simulation model developed in this study concerns sago pondweed. The following appendices are included in this report: model listing (Appendix A), variable listing (Appendix B), and a discussion of manipulation of literature data used for the model equations (Appendix C). A user's manual is published in Best and Boyd (in preparation). 


\section{POTAM: Description of Model}

\section{Modeling Concepts}

The POTAM (Version 1.0) model simulates growth of a typical monoecious sago pondweed community. In the model, growth is considered to be the plant dry matter accumulation, including subterranean tubers, under ample supply of nitrogen and phosphorus, in a pest-, disease-, and competitor-free environment under the prevailing weather conditions. At least one plant cohort waxes and wanes per season in different climatological regions, varying from temperate to tropical. The rate of dry matter accumulation is a function of irradiance, temperature, $\mathrm{CO}_{2}$ availability, and plant characteristics. The rate of $\mathrm{CO}_{2}$ assimilation (photosynthesis) of the plant community depends on the radiant energy absorbed by the canopy, which is a function of incoming radiation, reflection at the water surface, attenuation by the water column, attenuation by the plant material, and leaf area of the community. From the absorbed radiation, the photosynthetic characteristics of individual shoot tips, and the $\mathrm{pH}$-determined $\mathrm{CO}_{2}$ availability, the daily rate of gross $\mathrm{CO}_{2}$ assimilation of the community is calculated. These calculations are executed in a set of subroutines added to the model.

Part of the carbohydrates produced is used to maintain the existing biomass. The remaining carbohydrates are converted into structural dry matter (plant organs). In the process of conversion, part of the weight is lost in respiration. The dry matter produced is partitioned among the various plant organs using partitioning factors defined as a function of the phenological cycle of the community. The dry weights of the plant organs are obtained by integration of their growth rates over time. The plant winters through tubers in the sediment without or with biomass present. All calculations are performed on a square meter basis. Since environmental factors and plant growth characteristics vary with depth, the water column and associated growth-related processes have been partitioned in 0.10-m depth classes in the model (Titus et al. 1975).

Seed formation has not been included in the model, because its role in maintaining an existing sago pondweed community at the same location in relatively shallow waters is believed to be minimal (Van Vierssen and Verhoeven 1983) and investment in terms of carbon allocation low (Doyle 2000). Dispersal and colonization of new habitats by seeds and axillary turions are recognized as 
important characteristics of sago pondweed (Yeo 1965; Kantrud 1990). The latter processes, however, are better described using other modeling approaches (based on logistic regression or on descriptions of population dynamics varying in time and in space), as discussed by Scheffer (1991).

POTAM requires as input physiological properties of the plant community (in this case of sago pondweed) and actual environmental and weather conditions at the site characterized by geographical longitude and latitude, i.e., height of the water column, water temperatures (optional), alkalinity, $\mathrm{pH}$, day length, daily maximum and minimum temperatures, and irradiance for each day of the year. It can be run for periods of 1 to 5 years.

\section{Modeling Approach}

POTAM is a mechanistic model that explains plant growth on the basis of the underlying processes, such as $\mathrm{CO}_{2}$ assimilation and respiration, as influenced by environmental conditions. This type of model follows the state-variable approach in that it is based on the assumption that the state of each system can be quantified at any moment and that changes in the state can be described by mathematical equations. In this type of model, state, rate, and driving variables are distinguished. State variables are quantities such as biomass and number of individuals of a population. Driving variables characterize the effect of environment on the system at its boundaries, such as climate and food supply. Each state variable is associated with rate variables that characterize its rate of change at a certain instant, as a result of specific processes. These variables represent flows of material between state variables, the values of which are calculated from the state and driving variables according to knowledge of the physical, chemical, and biological processes involved. After the values of all rate variables are calculated, they are then used to calculate the state variables according to the scheme: state variable at time $t+\Delta t$ equals state variable at time $t$ plus the rate at time $t$ multiplied by $\Delta t$. This procedure, called numerical integration, gives the new values of the state variables, from which the calculation of rate variables is repeated. To avoid instabilities, the time interval $\Delta t$ must be small enough so that the rates do not change materially within this period. This is generally the case when the time interval of integration is smaller than one-tenth of the "time coefficient" or "response time." This characteristic time of a system is equal to the inverse of the most rapid relative rate of change of one of its state variables. The smaller the time coefficient, the smaller the time interval of integration (Rabbinge and De Wit 1989).

The predictive ability of mechanistic models does not always live up to expectations. It should be realized, however, that each parameter estimate and process formulation has its own uncertainty, and that uncertainties in parameter estimates may accumulate in the prediction of the final yield. The primary aim of this model is to increase insight into the system studied by quantitatively integrating the current knowledge in a dynamic simulation model. By studying the behavior of such a model, better insight in the real system is gained. 


\section{Implementation}

The POTAM model was implemented as a FORTRAN77 program. For numerical integration, the Runge-Kutta technique is used, which allows employing a variable time-step. The program, as it is being run, integrates the equations once per day in the main subroutine MODEL (Figure 1); once per second in the subroutines calculating day length and instantaneous irradiance (ASTRO) and instantaneous gross assimilation (ASSIM); and three times per day in the subroutine calculating daily total gross assimilation (TOTASS; Gaussian integration). Instantaneous gross assimilation is calculated per second and converted to hourly rates within ASSIM.

Model approach and organization are similar to those used for agricultural crops (SUCROS1, Goudriaan et al. 1992). Several features of a generic growth model for submersed angiosperms (SUBANG, Best and Jacobs 1990), and for other submersed plant species (HYDRIL, Best and Boyd 1996; MILFO, Best and Boyd 1999; VALLA, Best and Boyd 2001) have been used.

POTAM runs within a FORTRAN Simulation Environment (FSE) shell, Version 2.1, to enable easy handling of input and output files and rapid visualization of the simulation results (Van Kraalingen 1995). It can be executed on most PCs as a stand-alone version, but it requires the use of DOS. Because of its language and simple structure, it will generally be compatible with ecosystem models that accept FORTRAN. Switching from a WINDOWS-based to a DOSbased system may be accomplished through the WINDOWS Start menu, by activating the Run option and typing CMD, then Enter.

The organization of the model and its subroutines in combination with the FSE shell is illustrated in Figure 1.

\section{Model Features}

Features of POTAM are as follows:

a. Phenology is tied indirectly to temperature through development rate, and is, therefore, independent of day of year; thus, the model can be used under climatological conditions ranging from temperate to tropical.

$b$. Plant growth starts from the subterranean tuber bank alone, which may range from tuber densities as low as one to a tuber bank with wintering plants present.

c. One or more plant cohorts can be active in temperate as well as tropical climates; in case of plantlet death during prolonged periods of negative net photosynthesis early in the season, the dead plant cohort is succeeded by the next sprouting plant cohort. 


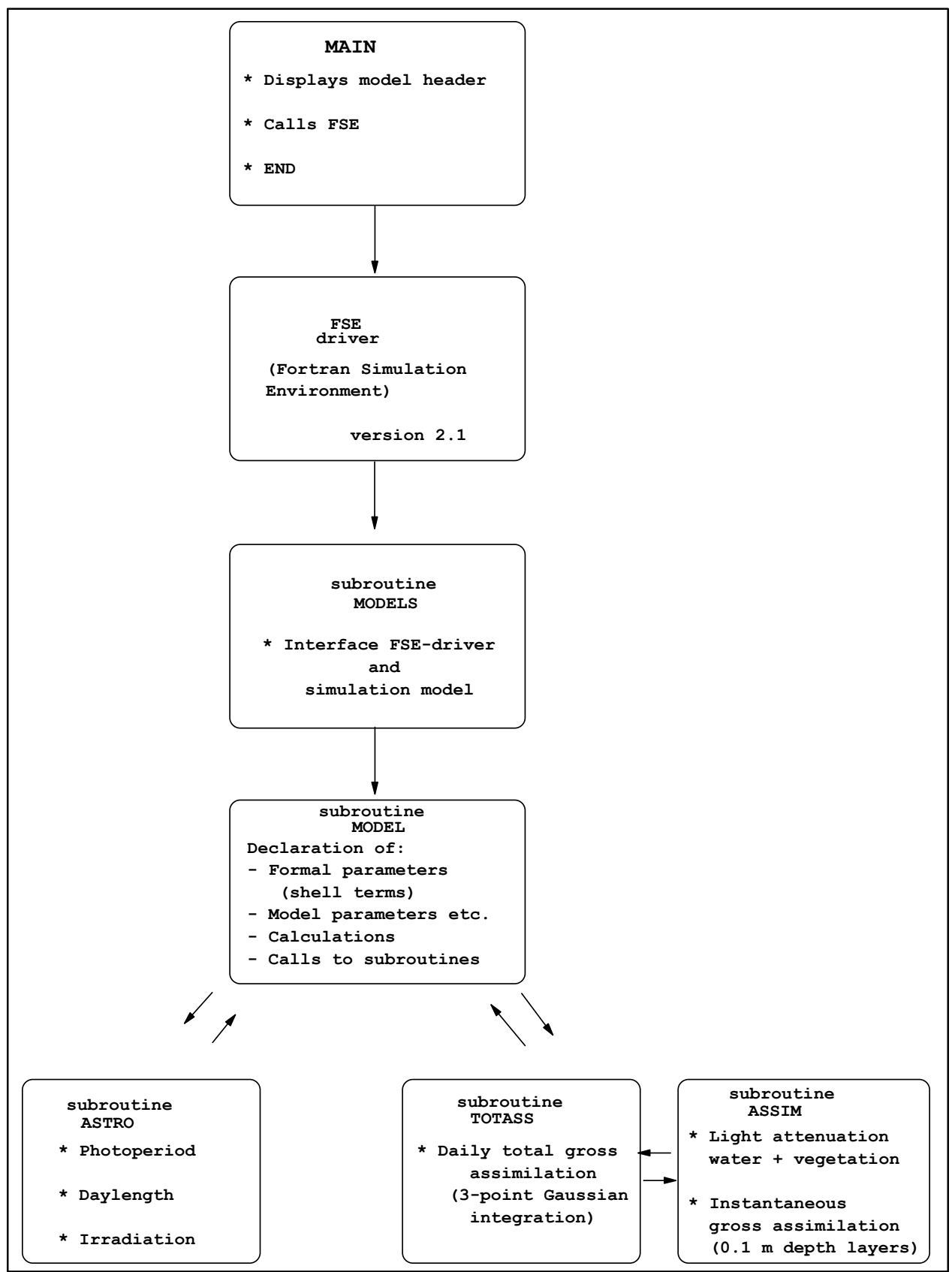

Figure 1. Relational diagram illustrating the organization of the model POTAM and its subroutines in combination with the FSE shell

d. Photosynthetic response is to instantaneous irradiance.

e. Air or water temperatures must be used to run the model. When air temperatures are used, the lag period between air temperature and (calculated) water temperatures can be varied between 1 and 7 days; this is an important feature for application in water bodies varying in depth, with large groundwater inputs, etc. 
$f$. The model can be used for communities at water depths that may vary between years and daily within the year, with depths ranging from 0.1 to $6.0 \mathrm{~m}$; this is an important feature for application in reservoirs and rivers.

g. Plant parameter values and climatological variables can be easily changed.

$h$. Effects of removal of plant biomass through cutting and of tubers through grazing can be calculated if desired. 


\section{Model Processes}

\section{Morphology, Phenological Cycle, and Development}

\section{Morphology and phenological cycle of sago pondweed}

Pondweeds are perennial submersed aquatic macrophytes that may regenerate from rhizomes, tubers, turions (detached winterbuds), or seeds. Because of its multiple regenerative strategies, stress tolerance, and competitive ability, which enable the plant to occupy mechanically disturbed areas, P. pectinatus is considered as a ruderal (Grime 1979; Kautsky 1987).

The monoecious $P$. pectinatus is a rooted submersed macrophyte, with a slender growth form composed by long stems with narrow, mostly filiform, leaves and emergent inflorescenses. In some populations long shoots are formed and branching is strongest at the end of the shoots. Luxuriant growth may lead to densely packed leaves, branches, and inflorescences in the upper part of the water column, with vegetation density increasing close to or on the water surface as water levels decrease. Other populations produce shorter shoots, and branching starts soon after the development of shoots (Den Hartog 1982). In the latter case, plant biomass is divided over the entire water column. Shoot length and branching appear to be characteristic of certain populations, but are also influenced by environmental conditions such as light (Van Wijk et al. 1988), current velocity, and nutrient availability (Van Wijk 1986; Vermaat and Hootsmans 1994a). In shallow waters, sago pondweed usually behaves as an annual, because it is sensitive to frost, like most submersed macrophytes, and decomposes rapidly in water (Lohammar 1938; Lapirov and Petukhova 1985). However, in deeper waters, green perennial sago pondweed shoots can be found (Hammer and Heseltine 1988). Flowering occurs once a year, from late June to August in the Northern Hemisphere (Yeo 1965). In mild climates, flowering may extend up to 5 months (Gupta 1968; Ramirez and San Martin 1984). Flowering usually coincides with peak biomass and is followed immediately by sloughing. The inflorescenses are bisexual spikelets on axillary peduncles, consisting of four staminate flowers surrounded by four pistillate ones (Uhl 1947). The production of viable seeds requires pollination on the water surface by buoyant pollen originating from a different specimen than the sago pondweed parent plant. Fruits mature under water (Mason 1969; Philbrick and Anderson 1987). The fruit of sago pondweed is a greenish, plump nutlet $2.5-5 \mathrm{~mm}$ wide. Other, perennial diaspores are subterranean tubers formed on the stolons within the sediment and 
axillary turions. Both tubers and turions are composed of a small amount of dividing tissue surrounded by several fleshy leaves. The parent plants senesce and disintegrate at the end of the growth season, and the tubers and turions hibernate within and/or on top of the sediment until their emergence the following spring, which completes the annual growth cycle. Tubers are depleted and disintegrate following the summer in which they were formed. Turions are smaller and are depleted earlier than tubers.

The plants may form numerous perennial diaspores, tubers and turions, and/or annual seeds. For example, in a single-season culture experiment, Yeo (1965) grew 36,000 subterranean tubers, 800 axillary turions, and 6,000 drupelets from one single turion, and 63,000 drupelets and 15,000 subterranean tubers from one single drupelet.

Tubers are considered the main propagules of sago pondweed in shallow waters because the fruitlike seeds, or drupelets, require stratification to germinate well in a temperate climate and lose their viability in deep waters and by burial within the sediment (Haag 1983), and because the species does not compete successfully with other seed-producing shallow-water species (Van Vierssen and Verhoeven 1983). Relatively small tubers and turions may survive drawdown conditions (Spencer 1987), but are usually sensitive to desiccation with sprouting being reduced by $>80$ percent in tubers after drying for 64 hours and turions being more sensitive than tubers (Basiouny et al. 1978). However, sago pondweed tubers exposed to desiccation treatments within the sediment up to 15 months proved to retain up to 30 percent of their sprouting potential in fresh water and up to 60 percent in brackish systems (Van Wijk 1989). Consequently, it is believed that sago pondweed may survive drawdown in a temperate climate only in the form of large tubers in the upper sediment layer.

Seeds may be important in long-distance dispersal and as insurance against local extinction. This is supported by the observations that (a) seed germination is enhanced by passage through duck guts up to a duration of 44 hours (Guppy 1897; Ridley 1930; De Vlaming and Proctor 1968), (b) in several established wetlands almost all sago drupelets were recovered close to the shore (Pederson and Van der Valk 1984), and (c) seedlings germinated from drupelets have seldom been observed (Van Wijk 1983, 1988).

\section{Description of development and phenological cycle in POTAM}

The phenology of a plant community, for which the development phase can be used as a measure, quantifies physiological age and is related to its morphological appearance. The development phase cannot be expressed simply as chronological age, because several environmental factors such as temperature and stress (e.g., nutrients, grazing) can speed up or reduce the rate of phenological development. Contrary to what is suggested by intuition, the rate of plant growth per se has no effect on phenological development, as long as the growth rate is not very low (Penning de Vries et al. 1989b, and citations therein). The concept of development phase is used to characterize the whole plant community; it is not appropriate for individual organs. 
Development phase (DVS) is a state variable in POTAM. DVS is dimensionless, and its value increases gradually within a growing season. The development rate (DVR) has the dimension $\mathrm{d}^{-1}$. The multiple of rate and time period yields an increment in phase.

The response of developmental rate to temperature in the current model is in accordance with the degree-day hypothesis (Thornley and Johnson 1990a). The idea is as follows. The mean temperature $\bar{T}_{i}\left({ }^{\circ} \mathrm{C}\right)$ for each day $i$ is measured, and a sum $h$ (degree-day sum, ${ }^{\circ} \mathrm{C}$ ) is formed according to the following equation:

$$
h=\sum_{i=1}^{j}\left(\bar{T}_{i}-T_{c}\right)
$$

which includes only those terms where $\bar{T}_{i}$ is above some threshold value $T_{c}$. When $h$ reaches a particular value, this signifies that a phase in development is complete, and this is generally associated with a biological event that occurs over a short period of time and is readily observed. The day-degree sum $h$ essentially integrates some underlying temperature-dependent processes. For sago pondweed, for example, there are various phases in the development of the plant, and the temperature sum is found to have a certain value for the successful completion of each. The temperature threshold $T_{c}$ may be different for each of these phases. The approach is based on the notion of a developmental rate whose response to temperature is approximately linear over a restricted temperature range. Comparison with actual temperature responses found in agricultural crops suggests that this is not unreasonable, and the method works well in practice. It is implicitly assumed that the organism possesses a developmental clock that is proceeding at the rate $k_{d}$ (development rate, $\left.\mathrm{d}^{-1}\right)$. In general, it is to be expected that the development rate $k_{d}$ may depend on a number of quantities. This can be represented by the following equation:

$$
k_{d}=f(V, P, E)
$$

in which $f$ represents some function of the state variables $V$, parameters $P$, and environmental quantities $E$. The temperature-sum rule works because the most important environmental variable is temperature, and the response to temperature is approximately linear.

The phenological cycle is described using sago pondweed in the Western Canal near Zandvoort, The Netherlands, 1987 (Appendix C), and climatological data from De Bilt, The Netherlands, 1987.

In the model, the temperature affecting development of sago pondweed can be chosen as equal to the daily average air temperature at the height of the growing point of the shoots, with a user-defined lag period to correct for deviations in temperature of the water body in which the aquatic community grows compared with air temperatures ( 7 days is nominal). It is more accurate to use water temperatures for this purpose, but since water temperatures are not always 
available for the site for which the user wants to run the model, POTAM can be run using either one.

Temperature can have a different effect on the rate of phenological development in the vegetative phase and in the reproductive phase. These differences indicate that the physiological process of development may not be the same before and after anthesis. Only one flowering period occurs in a temperate climate, i.e., from the end of June to August (Appendix C). Flowering behavior in a tropical climate is presumed to be similar to that in a temperate climate (Sahai and Sinha 1973).

The following DVRs were derived from the Western Canal field data (Appendix C): $0.015 \mathrm{~d}^{-1}$ prior to the flowering period (DVRVT), and $0.040 \mathrm{~d}^{-1}$ subsequently (DVRRT), at a reference temperature of $20^{\circ} \mathrm{C}$ and a temperature threshold of $3{ }^{\circ} \mathrm{C}$. These development rates are considered as typical for temperate regions. They are in the same order of magnitude as those found for the other submersed hydrilla (Hydrilla verticillata (L.F.) Royle), Eurasian watermilfoil (Myriophyllum spicatum L.), and American wildcelery (Vallisneria americana Michx.) (Best and Boyd 1996, 1999, 2001), but higher than that found for the terrestrial, tuber-forming, sweet potato (development rate of $0.006 \mathrm{~d}^{-1}$ at a reference temperature of $27^{\circ} \mathrm{C}$; Kooman 1995). For sago pondweed populations in the tropics, the same development rates and timings as in temperate regions were applicable (Sahai and Sinha 1973).

DVS has the value 0.0 when the simulation starts at the first Julian day number (Table 1). The simulation starts using an observed tuber bank density, with a certain, chosen (this chapter, section, "Wintering and Sprouting of Tuber Bank") individual tuber weight as initial values. The quantities of leaves, stems, and roots are set equal to 0 . If simulation of a sago pondweed community at another site is desired, the simulation can start also with wintering plants present; first, however, initial quantities of plant organs must be calculated.

For a sago pondweed community in a temperate climate, the sprouting of the tubers, i.e., the initiation of growth activity, occurs at DVS 0.211. Sprouts of the first plant cohort develop through remobilization of carbohydrates from the tubers. The sprouts elongate rapidly up to the water surface, and subsequently follow a typical umbrella-shaped spatial distribution within the water column. Anthesis is initiated at DVS 1.000 and finishes at DVS 2.000, just before new tubers are initiated. Tubers can be formed directly when initiated, in contrast to hydrilla where tuber formation lags behind tuber initiation (Best and Boyd 1996). Tuber formation, downward translocation, and senescence set in at DVS 2.001 and continue until the end of the year (Table 1).

Sago pondweed plants in tropical regions behave similarly in terms of DVS to those in temperate regions, except that tropical plants require on average a 1.6 times higher $3{ }^{\circ} \mathrm{C}$-day-degree sum to complete their individual life cycle than temperate cohorts. 


\begin{tabular}{|c|c|c|c|}
\hline \multicolumn{4}{|c|}{$\begin{array}{l}\text { Table } 1 \\
\text { Relationship between DVS of Sago Pondweed, Day of Year and } \\
3^{\circ} \mathrm{C} \text { Day-Degree Sum in a Temperate Climate (DVR Prior to } \\
\text { Flowering Period, DVRVT= 0.015; DVR from Flowering Period } \\
\text { Onward, DVRRT= 0.040) }\end{array}$} \\
\hline \multicolumn{2}{|l|}{ "Developmental Phase } & \multirow[b]{2}{*}{ Day Number } & \multirow{2}{*}{$\begin{array}{l}3^{\circ} \mathrm{C} \text { Day-Degree } \\
\text { Sum }\end{array}$} \\
\hline Description & DVS value & & \\
\hline $\begin{array}{l}\text { First Julian day number } \rightarrow \text { tuber } \\
\text { sprouting and initiation elongation }\end{array}$ & $0=0.210$ & $0=77$ & $1=193$ \\
\hline $\begin{array}{l}\text { Tuber sprouting and initial elongation } \rightarrow \\
\text { leaf expansion }\end{array}$ & $0.211=0.929$ & $78=187$ & $194=1301$ \\
\hline $\begin{array}{l}\text { Leaf expansion } \rightarrow \text { floral initiation and } \\
\text { anthesis }\end{array}$ & $0.930=1.000$ & $188=195$ & $1302=1434$ \\
\hline $\begin{array}{l}\text { Floral initiation and anthesis } \rightarrow \text { induction } \\
\text { of tuber formation, tuber formation and } \\
\text { senescence }\end{array}$ & $1.001=2.000$ & $196=233$ & $1435=2077$ \\
\hline $\begin{array}{l}\text { Tuber formation and senescence } \rightarrow \\
\text { senesced }\end{array}$ & $2.001=4.033$ & $234=365$ & $2078=3193$ \\
\hline Senesced & 4.033 & 365 & 3193 \\
\hline
\end{tabular}

\section{Maximum Biomass and Plant Density}

Seasonal biomass maxima can vary considerably over time and space. In both temperate and tropical climates usually one biomass peak per growth season was found, which occurred just before flowering. The highest standing crop of sago pondweed is found in saline and brackish lakes. In the temperate saline Swartvlei, between Port Elizabeth and Cape Town in South Africa (longitude $22^{\circ} 46^{\prime} \mathrm{E}$, latitude $\left.34^{\circ} \mathrm{S}\right) 1,952 \mathrm{~g}$ dry weight (DW) $\mathrm{m}^{-2}$ was measured by Howard-Williams (1978); in Lake Mariut, Egypt (longitude 30¹0' E, latitude 31 $\left.{ }^{\circ} 10^{\prime} \mathrm{N}\right), 1,568 \mathrm{~g}$ DW $\mathrm{m}^{-2}$ by Aleem and Samaan (1969); and in a brackish pool near Yerseke, The Netherlands (longitude $3^{\circ} 36^{\prime} \mathrm{E}$, latitude $51^{\circ} 30^{\prime} \mathrm{N}$ ), 1,312.5 $\mathrm{g} \mathrm{DW} \mathrm{m}^{-2}$ was found by Van Wijk et al. (1988). A somewhat lower maximum plant biomass of $712 \mathrm{~g}$ DW $\mathrm{m}^{-2}$ has been recorded for fresh water in Badfish Creek, WI, USA (approximate longitude $89^{\circ} 22^{\prime} \mathrm{W}$, latitude $43^{\circ} 4^{\prime} \mathrm{N}$ ), by Madsen and Adams (1988). Far lower biomass values are usually found under stressed conditions, such as caused by turbidity due to eutrophication and/or resuspension in shallow freshwater lakes in Poland (Ozimek et al. 1986), notably 5 to $112 \mathrm{~g} \mathrm{DW} \mathrm{m}^{-2}$, or exposure to high waves in the shallow Baltic Sea, Sweden (longitude $14^{\circ} 10^{\prime} \mathrm{E}$, latitude $\left.55^{\circ} 42^{\prime} \mathrm{N}\right), 4.8$ to $17.5 \mathrm{~g} \mathrm{DW} \mathrm{m}^{-2}$ by Kautsky (1987). Data on peak biomass in the tropics are scarce, but generally in the same order of magnitude as those in a temperate climate, i.e., 370-445 $\mathrm{g} \mathrm{DW} \mathrm{m}^{-2}$ (approximate longitude $78^{\circ} 28^{\prime}$ E, latitude $17^{\circ} 27^{\prime}$ N (Sinha 1970; Sahai and Sinha 1973). The highest published value on maximum biomass $\left(\leq 1,952 \mathrm{~g} \mathrm{DW} \mathrm{m}^{-2}\right)$ has been used to form the upper limit of plant biomass in the model. 
Sago pondweed exhibits clonal growth consisting of the production through the season of potentially interdependent, nonperennating plants, followed by the development of tubers, which become independent ramets upon disintegration of the parent plants in early fall. Since currently no evidence of interdependency of sago pondweed has been published, all intact plants and tubers produced in one season from an initial tuber are viewed as individual plants in the model.

Typical plant density is 30 plants $\mathrm{m}^{-2}$. It has been computed by dividing the maximum standing crop of an established monotypic sago pondweed vegetation at an anchorage depth of $2.5 \mathrm{~m}$ with a value of $82.27 \mathrm{~g} \mathrm{DW} \mathrm{m}^{-2}$ (Appendix C) by the highest average weight of an individual plant with neighbor plants $(2.76 \mathrm{~g} \mathrm{DW}$ plant $^{-1}$ ) in shallow waters studied in The Netherlands and the Camargue, France (Van Wijk 1989). Other literature reviewed did not provide sufficiently detailed information to enable calculations of plant density. Most of these studies dealt largely with weights of shoots composed by one stem with or without branches (e.g., Sher-Kaul et al. 1995), while whole plants are usually composed of several stems. Typical plant density indicates in the current case that it is possible that at some point in time different plant densities may occur, but that a typical established monotypic sago pondweed vegetation optimizes at 30 plants $\mathrm{m}^{-2}$. Lower densities may occur in the establishment phase, where some plants may not yet have neighbors and become relatively large, while higher plant densities may occur early in the season when $>30$ tubers $\mathrm{m}^{-2}$ have sprouted but the plantlets are subsequently thinned to 30 plants $\mathrm{m}^{-2}$ by self-shading of the vegetation.

In POTAM, plant density has been set to 30 plants $\mathrm{m}^{-2}$. This implies that plant density at the beginning of the growth season is in principle $30 \mathrm{~m}^{-2}$. Thus, the number of sprouting tubers in the tuber bank is $30 \mathrm{~m}^{-2}$, while the remaining tubers continue to senesce. However, at tuber bank densities lower than $30 \mathrm{~m}^{-2}$, the number of sprouting tubers is recalculated and set equal to the actual tuber bank density. If wintering plants are present, plant biomass is redistributed over 30 plants $\mathrm{m}^{-2}$.

\section{Wintering and Sprouting of Tuber Bank}

Tubers are the main storage organs for carbohydrates in wintering sago pondweed in a temperate climate. In tubers, concentrations of total carbohydrate reserves may reach 68-74 percent dry weight (Appendix C; Hodgson 1966), starch may reach 53 percent, and soluble sugars 17 percent dry weight (Appendix C). Tuber biomass is usually 0 in early summer and reaches a maximum in autumn. Because in most papers either plant biomass and tuber numbers without tuber biomass, or tuber numbers and biomass without plants are presented, it is difficult to present an accurate estimate of the tuber biomass range. Another complicating factor is that individual tuber weight varies substantially.

Tuber densities in sago pondweed tuber banks may vary over a large range, from 0 in early summer to a maximum of 3,975 $\mathrm{m}^{-2}$ in autumn (Van Wijk 1989). The large range found is probably due to (a) the patchy spatial distribution of the community over the water body, (b) limited number of replicate samples taken 
(Spencer et al. 1994), and (c) between site variation in anchorage depth of the vegetation.

The following densities have been published: (a) $45-115 \mathrm{~m}^{-2}$ on a waveexposed shallow site within the fresh-brackish Baltic Sea, Sweden (Kautsky 1987); (b) 270-385 $\mathrm{m}^{-2}$ in the shallow, fresh Lake Veluwe, The Netherlands (Van Dijk et al. 1992); (c) 1,330 and 3,975 $\mathrm{m}^{-2}$ in the oligohaline, sheltered ditch Salin De Badon and shallow pool Les Garcines, respectively, both in the Camargue, France (Van Wijk 1988); (d) 10 and 18 tuber size classes with average tuber weights of $0.061 \pm 0.006 \mathrm{~g}$ fresh weight (range 0.02 to $0.3 \mathrm{~g}$ ) and of $0.017 \pm$ $0.003 \mathrm{~g}$ fresh weight (range 0.02 to $0.46 \mathrm{~g}$ ) in the fresh Lake Veluwe and a brackish Texel ditch, respectively, both in The Netherlands (Vermaat and Hootsmans 1994a).

Published tuber weights (g dry weight tuber $\left.{ }^{-1}\right)$ are (a) 0.005 to $0.155(0.013 \mathrm{~g}$ on average; growth chamber study in California (Spencer and Anderson 1987)); (b) 0.017 (derived from $0.056 \mathrm{~g}$ fresh weight, and a dry:fresh weight ratio of $0.299+0.034$; harvested from freshwater irrigation canals in central California (Spencer 1987)); (c) 0.083 (Appendix C).

Tubers may lie dormant if not disturbed, and it is, therefore, to be expected that maintenance processes proceed at a very low level of activity. Tuber weight may decrease by tuber death and by the sprouting of tubers, which transform into plants. Tuber density may decrease by grazing by waterfowl and other animals. Both tuber weight and density may increase by the formation of new tubers (this chapter, section, "Induction and Formation of New Tubers").

Sprouting potential is substantial even without stratification, but it is increased by cold stratification during 4-10 weeks (Van Wijk 1989). Sprouting potential of the tubers is usually high in a temperate climate, being $\leq 80$ percent. Sprouting frequency in an established community is probably not important, unless it is very low, as long as the typical plant density of 30 plants $\mathrm{m}^{-2}$ is somehow reached, since plant density tends to play a lesser role in biomass production compared to space availability. Actual sprouting frequency under natural conditions is unknown. Sprouting frequency decreases with tuber burial depth: (a) small tubers in the size range of 0.003 to $0.012 \mathrm{~g} \mathrm{DW}$ proved less likely to emerge when planted at 5 and $10 \mathrm{~cm}$ than at $2.5-\mathrm{cm}$ depth; (b) only 30 percent of large tubers weighing $0.017 \mathrm{~g} \mathrm{DW}$ sprouted at 20-cm depth (Spencer 1987).

Whether or not sprouting is affected by day length and/or illumination is not known, but growth of sprouts from tubers was not (Spencer and Anderson 1987; Van Wijk 1989). Abundant sprouting was observed between 5.5 and $10{ }^{\circ} \mathrm{C}$ in the Western Canal near Zandvoort, The Netherlands (Appendix C), and $25^{\circ} \mathrm{C}$ (Spencer and Anderson 1987, California; Van Wijk 1989, France); but sprouting was lower at $25^{\circ}$ than at $20^{\circ} \mathrm{C}$ (Van Wijk 1989). Sprouting usually takes place early in the season. The earliest date mentioned is the beginning of April, when the first shoots were observed in the Western Canal, The Netherlands, in 1987 (Appendix C). 
Death rates of tubers have not been published. The value for the relative death rate of tubers, $R D T U$, was found by applying the same differential equation as commonly used for simple exponential growth to describe continuous exponential decrease in tuber number, with a negative specific decrease rate (Thornley and Johnson 1990b; Hunt 1982). An RDTU of $0.026 \mathrm{~d}^{-1}$ (on number basis) was found for the sago pondweed population in a shallow ditch in Yerseke, The Netherlands, by converting tuber standing crop values (Figure 6 in Van Wijk 1988) into tuber numbers using Table 2 of Van Wijk (1988). Somewhat lower $R D T U$ values were found for other populations studied by Van Wijk. The latter $R D T U$ value is far lower than that of $0.36 \mathrm{~d}^{-1}$ for hydrilla tubers estimated from simulations alone because virtually no seasonal changes in hydrilla tuber data had been published at that time (Best and Boyd 1996). Both plant species are expected to lose tubers through grazing by waterfowl, which may affect the amount of tubers sampled (and published). However, the relatively lower loss in sago pondweed may be explained by the relatively low tuber bank density of this plant (5-10 times higher in hydrilla), which may discourage foraging by waterfowl because it may require a relatively long search time as found for Vallisneria americana (Lovvorn 1989; Lovvorn and Gillingham 1996).

Higher temperatures expedite turnover rates of plant tissues and increase maintenance costs. A temperature increase of $10{ }^{\circ} \mathrm{C}$ usually increases maintenance respiration by a factor of about 2 up to temperatures that usually kill plants (45 to $60{ }^{\circ} \mathrm{C} ; Q_{10}=2$ at a reference temperature of $20^{\circ} \mathrm{C}$ (Penning de Vries et al. 1989a)). The value of 2 for $Q_{10}$ appears to be a reasonable average, but lower and higher values have been reported also (Amthor 1984).

In POTAM, initial tuber biomass has been set at $19.92 \mathrm{~g}$ dry weight $\mathrm{m}^{-2}$. The latter value was calculated by multiplication of the measured tuber number per plant $\left(8\right.$ plant $\left.^{-1}\right)$ and mean tuber weight $\left(0.083 \mathrm{~g} \mathrm{DW} \mathrm{tuber}^{-1}\right)$ at a $1.0-\mathrm{m}$ anchorage depth in the Western Canal near Zandvoort (Appendix C), by the commonly found plant density $\left(30 \mathrm{~m}^{-2}\right)$, resulting in 240 tubers $\mathrm{m}^{-2}$.

Sprouting is a function of development phase through the $3{ }^{\circ} \mathrm{C}$ day-degree sum; it occurs between DVS 0.211 and the flowering period of the plant population. Sprouting frequency has been set equal to the number of plants per surface area, i.e., at 30 sprouts $\mathrm{m}^{-2}$.

The relative tuber death rate is set at $0.026 \mathrm{~d}^{-1}$. It is presumed to be influenced by temperature through a relative effective temperature function, $T E F F$. This function describes processes relative to a reference temperature of $20^{\circ} \mathrm{C}$ at which the function has the value of 1 , to increase with a $Q_{10}$ of 2 at temperatures $>20^{\circ} \mathrm{C}$, to increase between 0 and $5^{\circ} \mathrm{C}$ from 0.0001 to 0.5 , and to decrease with a $Q_{10}$ of 2 at temperatures $<20^{\circ} \mathrm{C}$. A similar approach to account for temperature effects on maintenance respiration has been followed by Thornley and Johnson (1990a). 


\section{Initial Growth of Sprouts}

Tubers sprout and plantlets initially elongate, depleting the tuber carbohydrate reserves (starch up to 53 percent DW (Appendix C)). Sprouting can occur only in tubers weighing at least $0.001 \mathrm{~g} \mathrm{DW} \mathrm{tuber}^{-1}$ (Spencer 1987).

Whether or not these plantlets survive at the plant height they can maximally reach by merely depleting their carbohydrate reserves depends on the size and the carbohydrate efflux due to growth respiration of the tuber, and the carbohydrate influx in the plants because of photosynthesis.

The elongation potential of sprouts emerging from tubers is limited, i.e., $0.00714 \mathrm{~m}$ for tubers ranging in weight from 0.0054 to $0.155 \mathrm{~g} \mathrm{DW}$ tuber $^{-1}$ (Spencer 1987; Spencer and Anderson 1987). Thus, plants can rise one layer $0.1 \mathrm{~m}$ deep in the water column only when they can fill that layer with a minimum of 0.0076 or maximum of $0.2170 \mathrm{~g}$ plant DW.

Respiration of tubers is low when tubers are in a dormant state. A rate of $0.00312 \mathrm{~g} \mathrm{CO}_{2}$ tuber $^{-1} \mathrm{day}^{-1}$ at $10^{\circ} \mathrm{C}$ was derived from measurements in $0.083 \mathrm{~g}$ DW dormant tubers (Appendix C). This is based on the following: (a) dormant tuber respiration rate is $0.003623 \pm 0.0003 \mathrm{~g} \mathrm{CO}_{2} \mathrm{~g} \mathrm{DW}^{-1} \mathrm{~h}^{-1}$ at $20^{\circ} \mathrm{C}$;

(b) temperature influences respiration as described in the section "Wintering and Sprouting of Tuber Bank." This means that the latter tuber can survive for 27 days after sprouting if light for photosynthesis is lacking $\left(0.00312 \mathrm{~g} \mathrm{CO}_{2}\right.$ tuber $^{-1}$ day $^{-1} \times 27$ days $=0.083 \mathrm{~g}$ tuber). Consequently, sprouting tubers of this size die after a survival period of 27 days without net photosynthesis taking place. Larger tubers have longer and smaller tubers shorter survival periods.

In the model, tuber bank weight is calculated from initial tuber number and individual tuber weight read from the input file.

Tubers sprout, provided conditions allowing sprouting are met: (a) proper degree-day sum and (b) sufficient tuber bank weight.

Remobilization of tuber carbohydrates occurs by sprouting. Remobilization is the conversion of part of the carbohydrate reserves into sprout material via a relative tuber-to-plant conversion rate $(R O C)$. For $R O C$ of sago pondweed, the same value as for hydrilla tubers was used $\left(0.0576 \mathrm{~g} \mathrm{CH}_{2} \mathrm{O} \mathrm{g}\right.$ tuber $\mathrm{DW}^{-1} \mathrm{~d}^{-1}$ (Best and Boyd 1996)). These carbohydrates are allocated to the plant organs following a fixed biomass partitioning pattern (see section "Light, Photosynthesis, Maintenance, Growth, and Assimilate Partitioning in Sago Pondweed Plants"). Elongation occurs by filling each successive water layer from hydrosoil to the water surface with the minimum shoot biomass required $(0.0076 \mathrm{~g}$ plant $\mathrm{DW}$ plant $^{-1}$, termed CRIFAC). Remobilization and subsequent growth continue until the carbohydrates of the sprouting tubers are depleted.

Sprouting tubers die if the resulting plant biomass has a negative net assimilation rate over a user-defined number of days (SURPER; 27 days is nominal), and the program stops with a warning KCOUNT. 
After the death of one tuber class, one or more other tuber classes can sprout, provided tubers are available and the day-degree sum (Table 1) is lower than required for flowering. The program can resume running for the same year after the user presses ENTER provided the proper conditions are met.

A relational diagram illustrating the wintering and sprouting tubers of sago pondweed is shown in Figure 2.

The following equations describe wintering and sprouting of the tuber bank:

$$
\begin{aligned}
& T W G T U B=N P L \times I N T U B \\
& N D T U B=N D T U B-(N T U B D-N T U B P D) \\
& N T U B D=R D T U \times N D T U B \times T E F F \\
& I F(D V S . G E .0 .291 . A N D . D V S . L T .1 .) T H E N \\
& I F(T W G T U B . L E .(0.01 \times N P L \times I N T U B)) N G T U B=0.0 \\
& N G T U B=N P L \\
& T W G T U B=I N T G R L(T W G T U B,-R E M O B, D E L T) \\
& R E M O B=T W G T U B \times R O C \times T E F F
\end{aligned}
$$

where

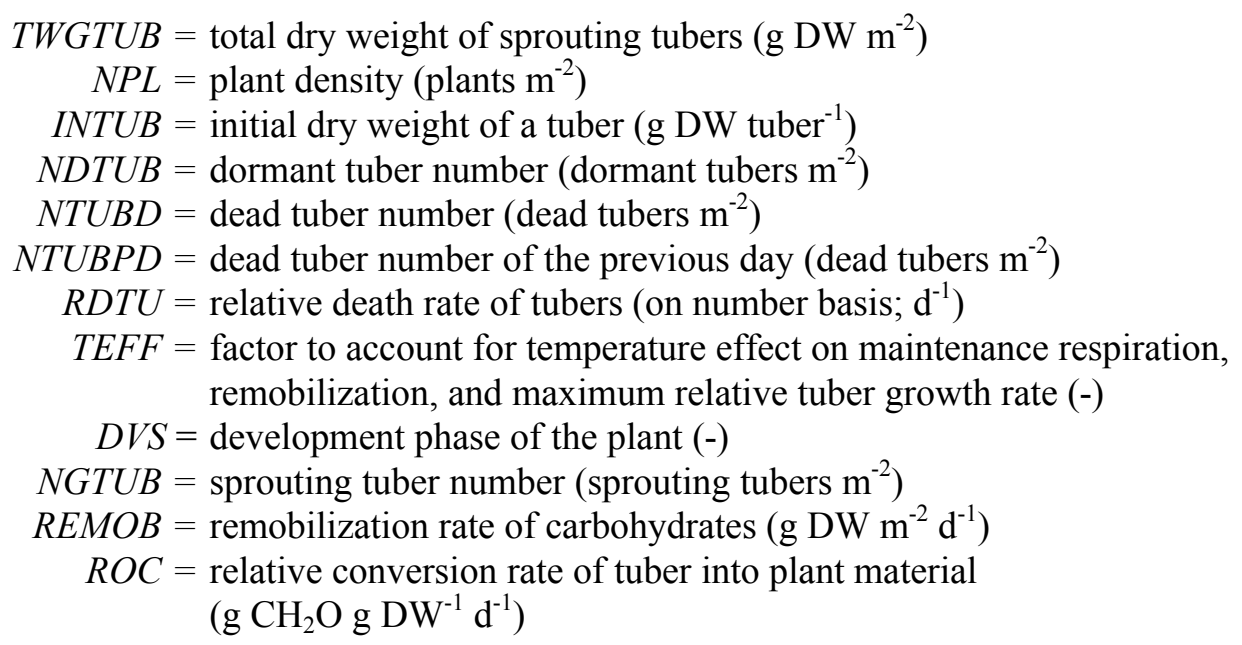




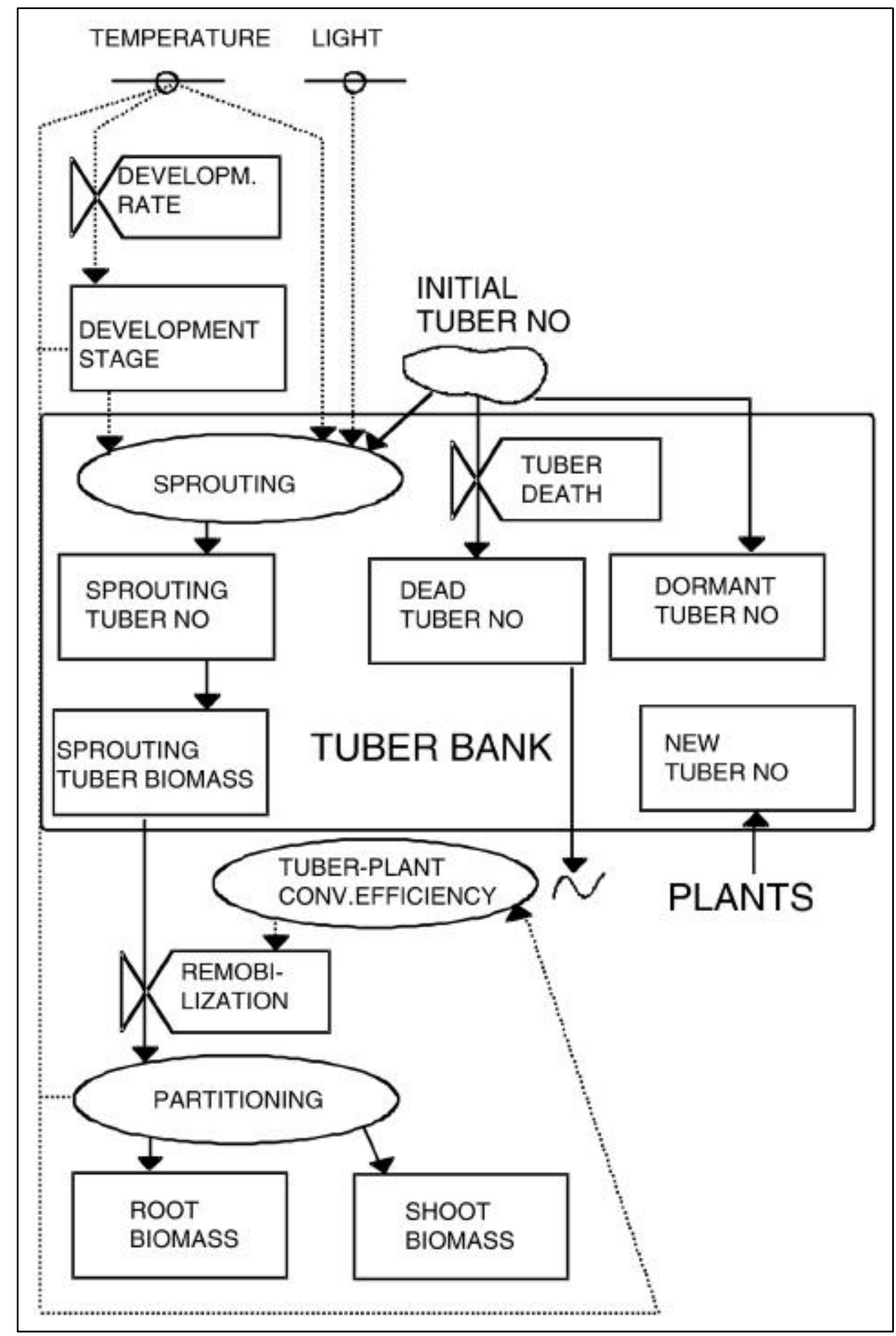

Figure 2. Relational diagram illustrating the wintering and sprouting of tubers in sago pondweed 


\section{Light, Photosynthesis, Maintenance, Growth, and Assimilate Partitioning in Sago Pondweed Plants}

\section{Light}

Light availability is an important factor controlling the distribution and abundance of submersed macrophytes. In aquatic systems light can be attenuated rapidly by water and its suspended solids, and by macrophytes themselves. A relatively small part of the irradiance can be reflected by the water surface.

In the model, the measured daily total irradiance (wavelength 300-3000 nm) is used as input. Only half of the irradiance reaching the water surface is considered to be photosynthetically active and is, therefore, used to calculate $\mathrm{CO}_{2}$ assimilation. Six percent of the irradiance is reflected by the water surface (Golterman 1975).

The subsurface irradiance is attenuated by dissolved substances and particles within the water column resulting in a site- and season-specific extinction coefficient. Moreover, the vertical profiles of the radiation within the plant community layers are characterized. The absorbed irradiance for each horizontal community layer is derived from these profiles. The community-specific extinction coefficient, $K$, is assumed to be constant throughout the year and given a value of $0.095 \mathrm{~m}^{2} \mathrm{~g} \mathrm{DW}^{-1}$ measured in the canopy of a sago pondweed community in the Western Canal near Zandvoort, The Netherlands (Appendix C). Other lower community-specific extinction coefficients of 0.0183 and $0.020 \mathrm{~m}^{2} \mathrm{~g}$ $\mathrm{DW}^{-1}$ have been found by Sher-Kaul et al. (1995) and Westlake (1964) (used in a different sago pondweed growth model by Hootsmans 1991).

The incoming irradiance is attenuated by the shoots, part of which is absorbed by the photosynthetic plant organs, i.e., the leaves.

$$
\begin{aligned}
I R Z_{i+1} & =I R Z_{i} \times e^{\left(-T L \times L-K \times S C_{i}\right)} \\
I A B S_{i} & =\frac{\left(I R Z_{i}-I R Z_{i+1}\right) \times S C_{i} \times K}{\left(K \times S C_{i}+T L \times L\right)} \\
I A B S L_{i} & =I A B S_{i} \times F L
\end{aligned}
$$

where

$$
\begin{aligned}
I R Z_{i}= & \text { photosynthetic active part of total irradiance on top of depth layer } i \\
& \left(\mathrm{~J} \mathrm{~m}^{-2} \mathrm{~s}^{-1}\right) \\
T L= & \text { thickness depth layer }(0.10 \mathrm{~m}) \\
L= & \text { light extinction coefficient of water }\left(\mathrm{m}^{-1}\right) \\
K= & \text { plant-specific extinction coefficient }\left(\mathrm{m}^{2} \mathrm{~g} \mathrm{DW}^{-1}\right) \\
S C_{i}= & \text { shoot dry matter in depth layer } i\left(\mathrm{~g} \mathrm{DW} \mathrm{m}^{-2}\right) \\
I A B S_{i}= & \text { total irradiance absorbed in depth layer } i\left(\mathrm{~J} \mathrm{~m}^{-2} \mathrm{~s}^{-1}\right) \\
I A B S L_{i}= & \text { total irradiance absorbed by plant shoots in depth layer } i\left(\mathrm{~J} \mathrm{~m}^{-2} \mathrm{~s}^{-1}\right) \\
F L= & \text { leaf dry matter allocation to each layer of the vegetation }(\text { relative; }-)
\end{aligned}
$$




\section{Photosynthesis}

In the model, the instantaneous rates of gross assimilation are calculated from the absorbed light energy and the photosynthesis light response of individual shoots, here used synonymously with leaves.

The photosynthesis light response of leaves is described by the exponential function

$$
F G L=S C_{i} \times A M A X \times\left(1-\exp \left[\frac{-E E \times I A B S_{i} \times 3600}{A M A X \times S C_{i}}\right]\right)
$$

where

$F G L=$ instantaneous gross assimilation rate per depth layer $\left(\mathrm{g} \mathrm{CO}_{2} \mathrm{~m}^{-1} \mathrm{~h}^{-1}\right)$

$A M A X=$ actual $\mathrm{CO}_{2}$ assimilation rate at light saturation for individual shoots $\left(\mathrm{g} \mathrm{CO}_{2} \mathrm{~g} \mathrm{DW}^{-1} \mathrm{~h}^{-1}\right)$

$E E=$ initial light-use efficiency for shoots $\left(\mathrm{g} \mathrm{CO}_{2} \mathrm{~J}^{-1}\right.$ absorbed $)$

For photosynthetic activity at light saturation $(A M X)$ the value of $0.019 \mathrm{~g} \mathrm{CO}_{2}$ $\mathrm{g} \mathrm{DW}^{-1} \mathrm{~h}^{-1}$ was used. This value was calculated by converting the maximum net oxygen production of sago pondweed apices in May of $13.5 \mathrm{mg} \mathrm{O}_{2} \mathrm{~g} \mathrm{DW}^{-1} \mathrm{~h}^{-1}$ into $\mathrm{mg} \mathrm{CO}_{2} \mathrm{~g} \mathrm{DW}^{-1} \mathrm{~h}^{-1}$. The plant population studied grew in the shallow, fresh River Susa, Denmark (Van der Bijl et al. 1989). In Van der Bijl's study, photosynthetic activity of apices always greatly exceeded that of intermediate and basal plant parts, and was usually in the order of $0.012 \mathrm{~g} \mathrm{CO}_{2} \mathrm{~g} \mathrm{DW}^{-1} \mathrm{~h}^{-1}$ during summer. A lower value for AMX of $0.0099 \mathrm{~g} \mathrm{CO}_{2} \mathrm{~g} \mathrm{DW}^{-1} \mathrm{~h}^{-1}$ was found by Vermaat and Hootsmans (1994b; Chapter 6) for sago pondweed from a shallow freshwater lake incubated in the laboratory. Using the latter value for runs into their SAGA model indicated that a 20 percent increased AMX, i.e., of $0.012 \mathrm{~g}$ $\mathrm{CO}_{2} \mathrm{~g} \mathrm{DW}^{-1} \mathrm{~h}^{-1}$, was required to generate realistic plant biomass results. An even lower value for AMX of $0.0055 \mathrm{~g} \mathrm{CO}_{2} \mathrm{~g} \mathrm{DW}^{-1} \mathrm{~h}^{-1}$ was found by Madsen and Adams (1988) for sago pondweed from a freshwater river incubated in the laboratory.

Light- and carbon-saturated photosynthetic rates of sago pondweed can be far higher $\left(0.039 \mathrm{~g} \mathrm{CO}_{2} \mathrm{~g} \mathrm{DW}^{-1} \mathrm{~h}^{-1}\right)$ (Appendix C), suggesting that photosynthetic activity in waters with low dissolved inorganic carbon concentrations $(<3.5 \mathrm{mmol}$ $\left.\mathrm{L}^{-1}\right)$ or high $\mathrm{pH}(>8)$ can be carbon limited.

Gross assimilation rate at light saturation shows a distinct seasonal pattern and tends to decrease with aging (Appendix C; Van der Bijl et al. 1989). Although a function describing this relationship (AMDVST) has been included in the model, it is not active in the nominal version (it has the value of 1) since running the model showed that it was not quantitatively important.

Daily changes in $\mathrm{pH}$ and oxygen concentrations may affect $A M X$. A reduction factor, $R E D A M$, can be used to take these effects into account by reducing the $A M X$ by a factor between 0 and 1 for the whole day. REDAM currently has the value of 1 , because $\mathrm{pH}$ in the sago pondweed communities in the Western Canal 
near Zandvoort oscillated around 8.4 (Appendix C), where actual and potential photosynthetic activities at light saturation are similar. Sensitivity of sago pondweed to changes in oxygen concentration is unknown, and is not accounted for in the model.

Changes in temperature affect $A M X$. A fitted, relative function, $A M T M P T$, describes the effect of daytime temperature on $A M X$, which is based on the measured photosynthetic response of sago pondweed to temperature and has its optimum at $30^{\circ} \mathrm{C}$ (Appendix C; Madsen and Adams 1988).

For photosynthetic light-use efficiency $(E E)$, a value of $11 \times 10^{-6} \mathrm{~g} \mathrm{CO}_{2} \mathrm{~J}^{-1}$, typical for $\mathrm{C}_{3}$ plants, was used (Penning de Vries and Van Laar 1982a).

Substituting the appropriate value for the absorbed photosynthetically active radiation yields the assimilation rate for each specific shoot layer.

The instantaneous rate of gross assimilation over the height of the plant community is calculated by relating the assimilation rate per layer to the community-specific biomass distribution and by subsequent integration of all community layers.

The daily gross assimilation rate is calculated using the Gaussian integration method. This method specifies the discrete points at which the value of the function to be integrated has to be calculated, and the weighting factors that must be applied to these values to attain minimum deviation from the analytical solution. A three-point method performs very well for calculating daily total assimilation (Goudriaan 1986; Spitters 1986).

\section{Maintenance, growth, and assimilate partitioning}

Maintenance. Some of the carbohydrates formed are respired to provide energy for maintaining the existing plant components. The maintenance costs increase with metabolic activity, probably because of higher enzyme turnover and higher transport costs (Penning de Vries 1975).

The maintenance cost can be estimated from the chemical composition of the plant. Typical maintenance coefficients for various plant organs have been derived, based on numerous chemical determinations in agricultural crops. They typically range from 0.010 to $0.016 \mathrm{~g} \mathrm{CH}_{2} \mathrm{O}$ g ash-free dry weight $(\text { AFDW })^{-1} \mathrm{~d}^{-1}$ (Penning de Vries and Van Laar 1982b).

In POTAM, the maintenance coefficients already mentioned are used to calculate the maintenance requirement of the plants. Maintenance respiration has been related to temperature by the same relative effective temperature function as used for the remobilization and relative tuber growth and death rates. Maintenance costs for the tubers have been discussed earlier in the section "Wintering and Sprouting of Tuber Bank."

The following equations describe maintenance costs for sago pondweed plants: 


$$
\begin{aligned}
& M A I N T S=0.016 \times T W L G+0.010 \times T W S G+0.015 \times T W R G \\
& M A I N T=M A I N T S \times T E F F
\end{aligned}
$$

where

MAINTS $=$ maintenance respiration rate of the vegetation at reference temperature $\left(\mathrm{g} \mathrm{CH}_{2} \mathrm{O} \mathrm{m}^{-2} \mathrm{~d}^{-1}\right)$

$T W L G=$ total dry weight of live leaves $\left(\mathrm{g} \mathrm{DW} \mathrm{m}^{-2}\right)$

$T W S G=$ total dry weight of live stems $\left(\mathrm{g} \mathrm{DW} \mathrm{m}^{-2}\right)$

$T W R G=$ total dry weight of live roots $\left(\mathrm{g} \mathrm{DW} \mathrm{m}^{-2}\right)$

$M A I N T=$ maintenance respiration of the vegetation $\left(\mathrm{g} \mathrm{CH}_{2} \mathrm{O} \mathrm{m}^{-2} \mathrm{~d}^{-1}\right)$

$T E F F=$ factor accounting for effect of temperature on maintenance respiration (-)

Growth. Assimilates in excess of maintenance costs are available for conversion into structural plant material. In this conversion process of the glucose molecule, $\mathrm{CO}_{2}$ and $\mathrm{H}_{2} \mathrm{O}$ are released. The assimilates required to produce one unit weight of any particular plant organ can be calculated from its chemical composition and the assimilate requirements of the various chemical components. Typical values are $1.46 \mathrm{~g} \mathrm{CH}_{2} \mathrm{O} \mathrm{g} \mathrm{DW}$ for leaves, 1.51 for stems, and 1.44 for roots (Penning de Vries and Van Laar, 1982b; Penning de Vries et al. 1989a), confirmed by Griffin (1994). At higher temperatures the conversion processes are accelerated, but the pathways are identical. The recently determined construction costs for several submersed plant species using a different method (Williams et al. 1987) are generally lower, ranging from 0.99 to 1.11 (Spencer et al. 1997).

However, some of the latter plants are relatively poor in nitrogen and transport costs have not been included, both factors which may have contributed to the lower cost found.

In POTAM the construction costs typical for agricultural plants have been used, since construction costs calculated for sago pondweed leaves with an average chemical composition were similar to those in agricultural plants, i.e., $1.465 \mathrm{CH}_{2} \mathrm{O} \mathrm{g} \mathrm{DW}{ }^{-1}$ (for calculation costs for leaves, see Appendix C), and stems and roots were presumed to be similar also.

The following equation describes growth:

$$
G T W=\frac{[(R E M O B \times C V T)+G P H O T-T R A N S-M A I N T]}{A S R Q}
$$

where

$G T W=$ dry matter growth rate of the vegetation (plants excluding tubers) $\left(\mathrm{g} \mathrm{DW} \mathrm{m} \mathrm{d}^{-1}\right)$

$R E M O B=$ remobilization rate of carbohydrates $\left(\mathrm{g} \mathrm{CH}_{2} \mathrm{O} \mathrm{m}^{-2} \mathrm{~d}^{-1}\right)$

$C V T=$ conversion factor of translocated dry matter into $\mathrm{CH}_{2} \mathrm{O}(-)$

$G P H O T=$ daily total gross assimilation rate of the vegetation $\left(\mathrm{g} \mathrm{CH}_{2} \mathrm{O} \mathrm{m}^{-2} \mathrm{~d}^{-1}\right)$

TRANS $=$ translocation rate of carbohydrates $\left(\mathrm{g} \mathrm{CH}_{2} \mathrm{O} \mathrm{m}^{-2} \mathrm{~d}^{-1}\right)$

MAINT $=$ maintenance respiration rate of the vegetation $\left(\mathrm{g} \mathrm{CH}_{2} \mathrm{O} \mathrm{m}^{-2} \mathrm{~d}^{-1}\right)$ 


$$
\begin{aligned}
A S R Q= & \text { assimilate requirement for plant dry matter production } \\
& \left(\mathrm{g} \mathrm{CH}_{2} \mathrm{O} \mathrm{g} \mathrm{DW}\right.
\end{aligned}
$$

Assimilate partitioning. Assimilate partitioning is the process by which assimilates available for growth are partitioned over leaves, stems, roots, and/or storage organs. It depends on physiological age. Assimilate partitioning pattern in sago pondweed is not known. However, the biomass resulting from this process was partitioned for 80.0 percent over leaves, 12.5 percent over stems, and 7.5 percent over roots as documented in two well-developed sago pondweed communities in summer in The Netherlands (Appendix C; Sher-Kaul et al. 1995 ). These values are close to those published by Spencer and Anderson (1987), i.e., 90 percent over shoots and 10 percent over roots, with photoperiod having no effects.

Sago pondweed exhibits a typical umbrella-shaped depth distribution of shoot biomass from the top of the vegetation downwards. In a full-grown sago pondweed community in the Western Canal, The Netherlands, 78 percent of shoot biomass was found within $0.5 \mathrm{~m}$ of the sediment/water interface (Yeo 1965; Howard-Williams 1981; Appendix C).

In POTAM, assimilate partitioning is used synonymously with biomass partitioning, with the latter following the same distribution pattern as measured in full-grown plants, starting from the time when the shoot tips have reached the water surface.

Shoot biomass is allocated over the vertical axis via a dry matter partitioning coefficient function (DMPC) following the typical umbrella type shape. Allocation proceeds as follows. First plant biomass is allocated for 78.4 percent to the five depth layers starting from the water surface downwards, with a depth distribution of successively 4.3, 4.3, 23.1, 25.4, and 21.3 percent. Allocation to the layers below this $0.5 \mathrm{~m}$ is equal up to a total plant biomass share of 13 percent. When the amount of biomass allocated to a water/plant layer is lower than the critical biomass required to support plant biomass above that layer, the total number of plant layers is reduced with one and the biomass allocation procedure is redone. When five or fewer water layers are present, first the upper water layers are filled according to allocation pattern, and subsequently the remaining plant biomass is added and distributed equally over the found water layers. Roots always contribute 8.6 percent to total plant biomass. Vertical biomass distribution pattern is recalculated and redistributed by POTAM when an anchorage depth other than nominal $(1.3 \mathrm{~m})$ is chosen.

The following equation describes biomass partitioning over plant organs:

$$
\begin{aligned}
& G L V=F L V \times G T W \\
& G R T=F R T \times G T W \\
& G S T=F S T \times G T W
\end{aligned}
$$

where $F L V, F R T$, and $F S T$ are fractions of total dry matter increase allocated to leaves, roots, and stems, respectively (relative); GLV, GRT, and GST are dry 
matter growth rates of leaves, roots, and stems, respectively $\left(\mathrm{g} \mathrm{DW} \mathrm{m}^{-2} \mathrm{~d}^{-1}\right)$; and $G T W$ is dry matter growth rate of the vegetation (plants excluding tubers) (g DW $\left.\mathrm{m}^{-2} \mathrm{~d}^{-1}\right)$

A relational diagram illustrating photosynthesis, respiration, and biomass formation of sago pondweed is shown in Figure 3.

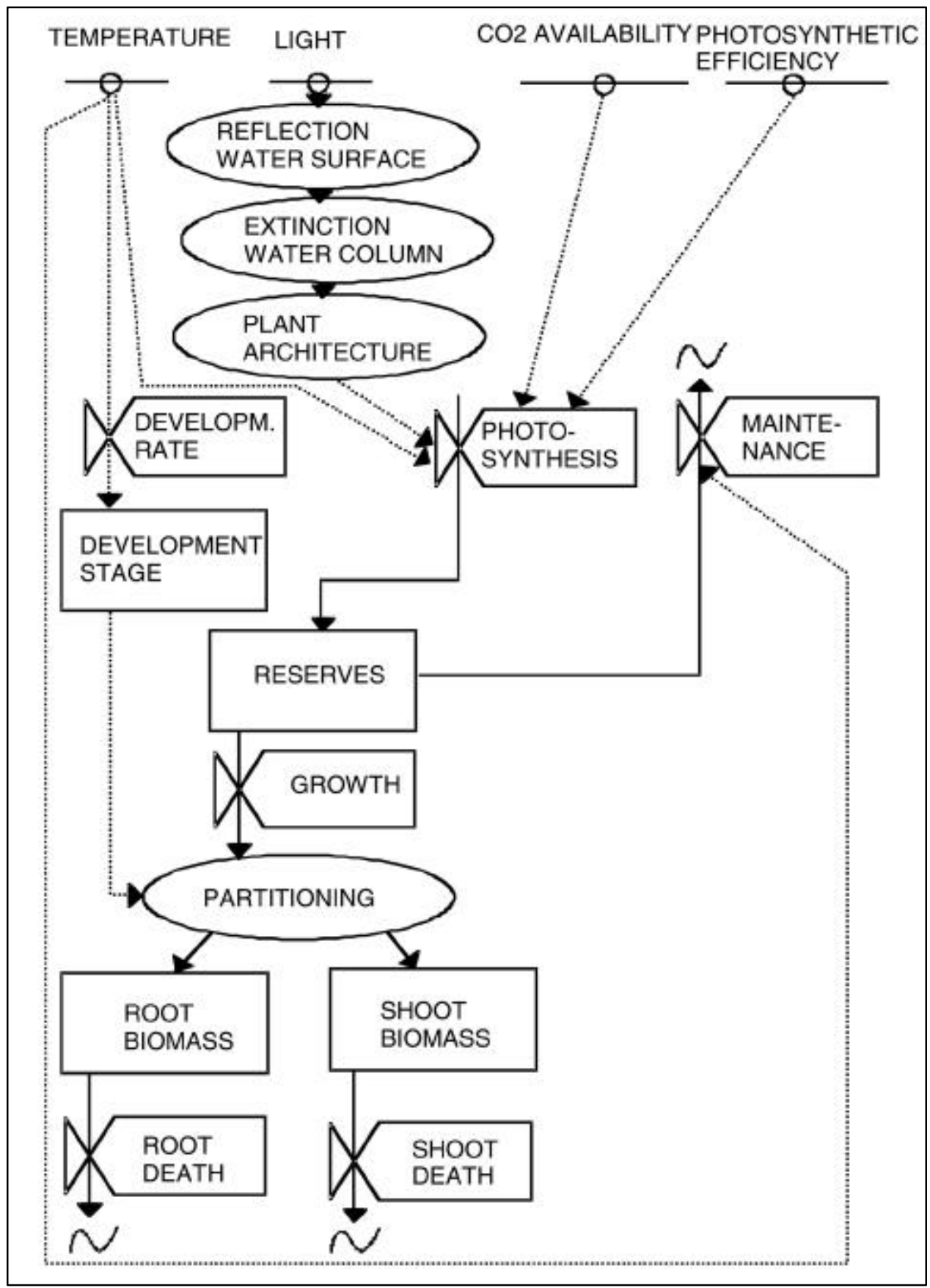

Figure 3. Relational diagram illustrating photosynthesis, respiration, and biomass formation in sago pondweed 


\section{Induction and Formation of New Tubers}

Tubers are formed just after flowering under relatively short day conditions (between 10 and $16 \mathrm{hr}$ light per day) and within a temperature range between 5.5 and $25^{\circ} \mathrm{C}$. This was concluded largely from two studies. Experiments by Spencer and Anderson (1987) in California indicated that sago pondweed plants grown at photoperiods varying between 10 and $16 \mathrm{hr}$ light per day for periods up to 56 days exhibited enhanced tuber production at a photoperiod between 10 and $12 \mathrm{hr}$.

Moreover, vegetative propagules appeared to be produced instead of shoot tissue under short-day conditions. A field study on Lake Veluwe, The Netherlands, revealed a sharp increase in tuber production after 15 July (air temperature $12{ }^{\circ} \mathrm{C}$, day length $16 \mathrm{hr}$ ) with maximum tuber number reached at 23 August (air temperature $21^{\circ} \mathrm{C}$, day length $13 \mathrm{hr}$ (Table 3 in Van Wijk 1988). It is possible that tuber induction in sago pondweed is triggered by phytochrome and is associated with increased abscisic acid levels, as in hydrilla (Van et al. 1978; Klaine and Ward 1984), Ceratophyllum demersum (Best 1982), and the terrestrial potato (Kooman 1995).

Tubers can be formed only by a plant (not by an already existing tuber). Environmental conditions favoring tuber formation occur in a temperate climate in spring and late summer. Since in this climate sago pondweed winters by tubers without plants, tubers can be formed only in late summer. However, in other warmer climates where sago pondweed may winter by plants and tubers, tuber formation may follow a different timing.

Tubers grow from assimilates translocated downward from the shoots. Translocation has not been measured in submersed plants. However, estimates based on data pertaining to other plants are 19 percent of net production in seagrasses (Wetzel and Neckles 1996), 35 percent in Eurasian watermilfoil (Best and Boyd 1996), and approximately 40 percent in hydrilla (Best and Boyd 1996). In terrestrial tuber-producing plants translocation was 29 percent of net production in cassava (Gijzen 1985) and 35 percent in certain potato varieties (Kooman 1995). The translocated material consisted largely of carbohydrates, and was considered as equivalent to starch (Gijzen 1985).

Individual tuber weight and tuber number concurrently formed by each plant depend on the photoperiod at which the plant grows. Individual tuber weight increased linearly with tuber number concurrently formed per plant at a photoperiod of $\leq 12 \mathrm{hr}$ light per day from 1 tuber with a weight of $0.016 \mathrm{~g} \mathrm{DW}$ tuber $^{-1}$ to 12 tubers with a mean weight of $0.155 \mathrm{~g} \mathrm{DW} \mathrm{tuber}^{-1}$ for plants grown for 56 days (Figure 4; Spencer and Anderson 1987). The plant material for this study originated from Omro, WI (longitude $44^{\circ} 02^{\prime}$ W, latitude $48^{\circ} 44^{\prime} \mathrm{N}$ ) while the study was performed in a growth chamber in Davis, CA (longitude $121^{\circ} 48^{\prime}$ $\mathrm{W}$, latitude $38^{\circ} 33^{\prime} \mathrm{N}$ ). This response to a short-day photoperiod is similar to that exhibited by Hydrilla verticillata L. (Van et al. 1978; Sutton et al. 1980; Klaine and Ward 1984; Spencer and Anderson 1986), Utricularia vulgaris L. (Winston and Gorham 1979), Myriophyllum verticillatum L. (Weber and Nooden 1974), and Hydrocharis morsus-ranae (Terras 1900). Tuber production was far (> 75 percent) lower in plants grown at 14- or 16-hr photoperiods than in plants cultivated at a $10-\mathrm{hr}$ photoperiod. The light level at which the plant grows is also 
important, since tuber weight increased about ten times with a doubling of the growth period (Spencer and Anderson 1987). This led to the conclusion that sago pondweed may follow an optimization strategy aimed at forming the largest possible tubers at the light level experienced, possibly because large tubers have a greater survival value than smaller ones. Based on the assumption that the plant follows this optimization strategy, an established plant population growing at a given light level will aim at forming only one tuber weight class, i.e., with an individual tuber weight that allows new plants to survive at that site.

Consequently, the differences in tuber weights found in tuber banks may be explained by difference in age between tuber classes, with the oldest class having a lower weight because the tubers have lost weight by senescence, and the youngest class having a lower weight because the tubers were not completely finished before the plants were fully senesced.

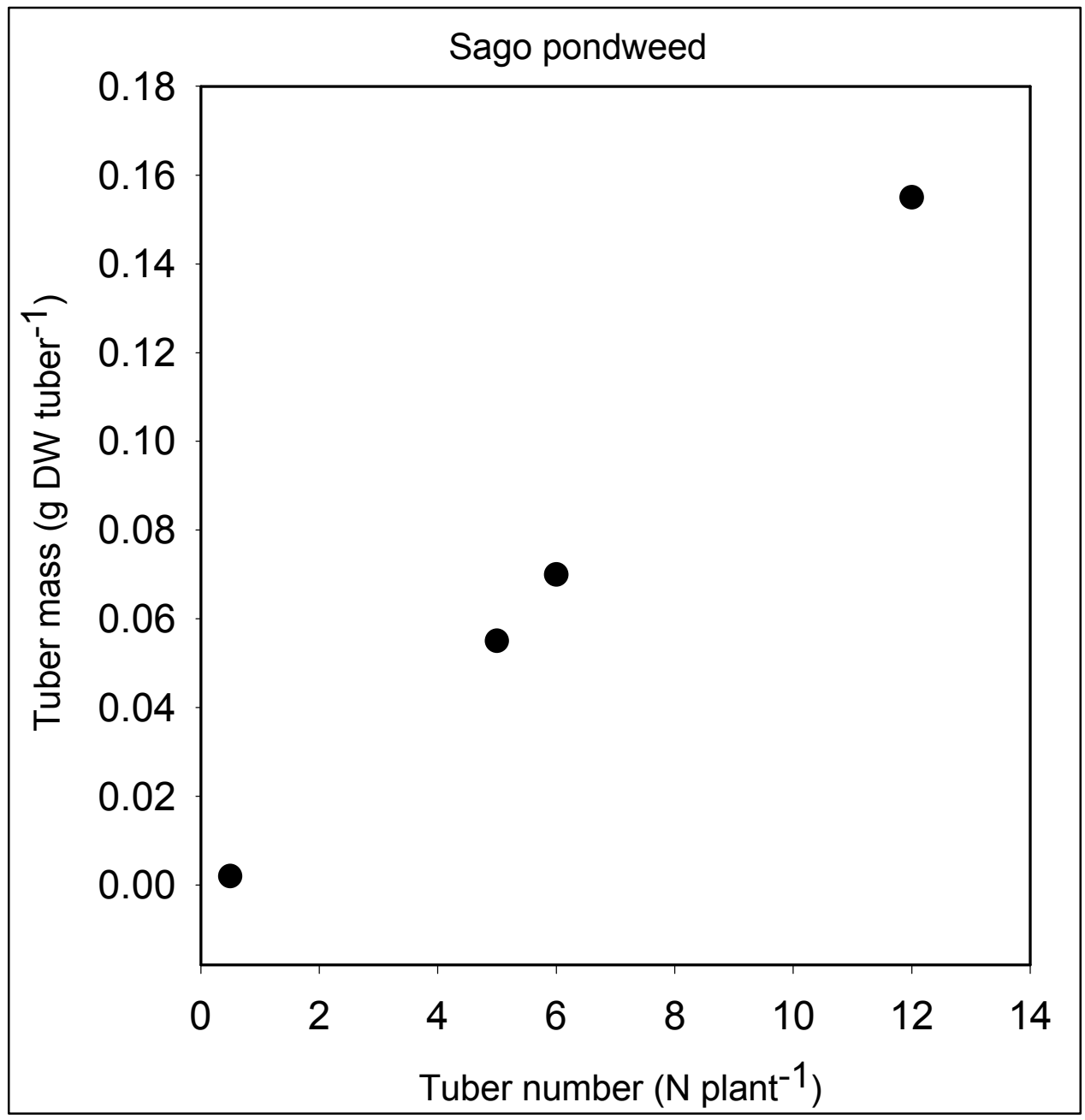

Figure 4. The relationship between tuber number concurrently initiated per plant and tuber size for sago pondweed (data from Spencer and Anderson 1987)

In the model, induction of tuber formation occurs at DVS $>1.0$, daylength $<16 \mathrm{hr}$, and a temperature range of 5 to $25^{\circ} \mathrm{C}$. Once initiated, a tuber class grows from translocated material until a preselected individual tuber weight is reached. 
Nominal values are 8 tubers with an 0.083 -g-DW individual tuber weight making up a 19.92-g-DW critical tuber weight class $($ TWCTUB; $8 \times 0.083 \times 30)$.

Transport of glucose costs dry matter, i.e., 36/38, whereas conversion of starch into glucose increases the dry matter with a factor $10 / 9$. Thus, the total transport "cost" of downward translocation is a factor $C V T=1.05(10 / 9 \times 36 / 38)$. The intensity of translocation is governed by the maximum relative growth rate of the tubers, $R T R L$, that consumes 19 percent of net production by the senescing plants, multiplied by $C V T$. This relative growth rate was found by applying the same differential equation as commonly used for simple exponential growth (Thornley and Johnson 1990b; Hunt 1982) to tuber data collected in the field (Table 1 in Van Wijk et al. 1988). Thus a maximum relative growth rate of tubers of $0.19 \mathrm{~d}^{-1}$ at a reference temperature of $20^{\circ} \mathrm{C}$ was computed. Temperature influences on the relative growth rate of tubers are described in the section "Wintering and Sprouting of Tuber Bank." Once finished, a tuber class is added to the dormant tuber bank, and the plant starts forming a new tuber class. Tuber initiation continues as long as environmental conditions permit, and tubers are formed as long as the plants can provide assimilates to fill them.

The following equations describe induction and formation of new tubers.

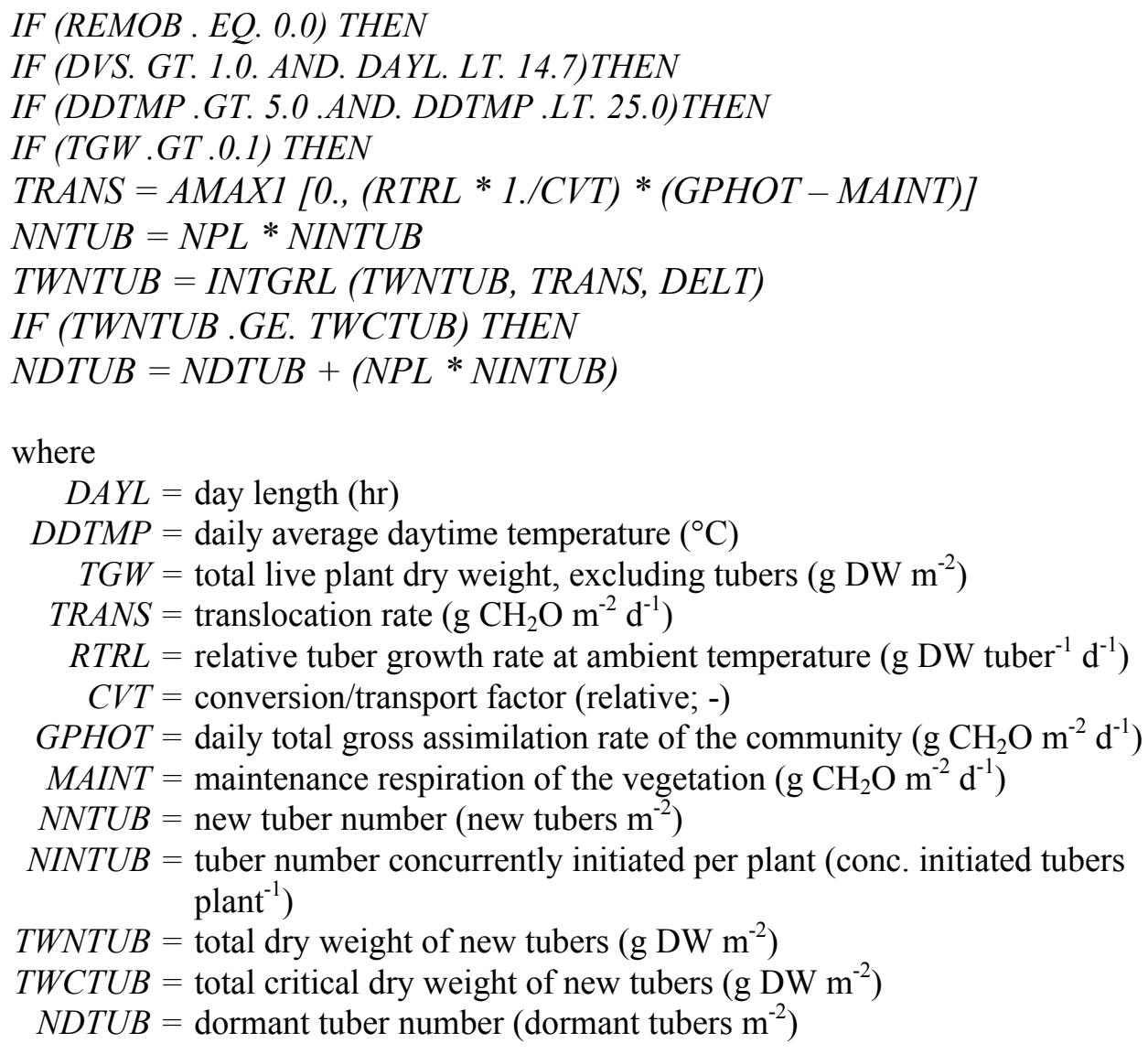




\section{Flowering and Senescence}

The occurrence of flowering affects subsequent metabolic activity of the vegetation. The timing of flowering is, therefore, extremely important for the physiological activity and biomass formation, while the actual investment of dry matter in flowers and seeds proves to be only minor (Yeo 1965; Van Wijk 1989). After flowering, senescence sets in, resulting in loss of particulate plant material, while a considerable part of net production is translocated downward to the tubers with the remainder of net production being allocated following the typical pattern described in the subsection "Maintenance, Growth, and Assimilate Partitioning."

Senescence refers to the loss of capacity to carry out essential physiological processes and to the loss of biomass. The fundamental processes involve physiological aging and protein (enzyme) breakdown. These processes are difficult to quantify. It is known that hormones are important messengers in this context, but it is not known precisely how they act. High temperature usually accelerates senescence.

In POTAM, the timing and value of relative death rate (RDR) of the plants have been derived from field observations on plant biomass in the Western Canal near Zandvoort (1-m depth class) (Appendix C). A mechanistic approach to senescence has been chosen by setting the death rate at a certain fraction of plant biomass lost per day once the conditions for growth deteriorate. The timing of onset of senescence was found by running the model repeatedly with different development rates and base and reference temperatures until a good fit between simulated and measured values was accomplished. Thus, initiation of senescence for plants was set at DVS 2.001. The value for the relative death rate of the plants was found by applying the same differential equation as commonly used for simple exponential growth, to describe exponential decrease in biomass after flowering, with a negative specific decrease rate. Thus, an RDR of $0.047 \mathrm{~d}^{-1}$ was found for the period between peak biomass and several days before plant biomass had disappeared. The latter value was used in the model. It is presumed to increase with temperature between 20 and $50{ }^{\circ} \mathrm{C}$ through a relative temperature function. This function describes processes relative to a reference temperature of $20{ }^{\circ} \mathrm{C}$ at which the function has the value of 1 , to increase with a $Q_{10}$ of 2 at temperatures between 20 and $40{ }^{\circ} \mathrm{C}$, and to increase further to the value of 1 at $50{ }^{\circ} \mathrm{C}$.

A relational diagram illustrating translocation and senescence is shown in Figure 5. 


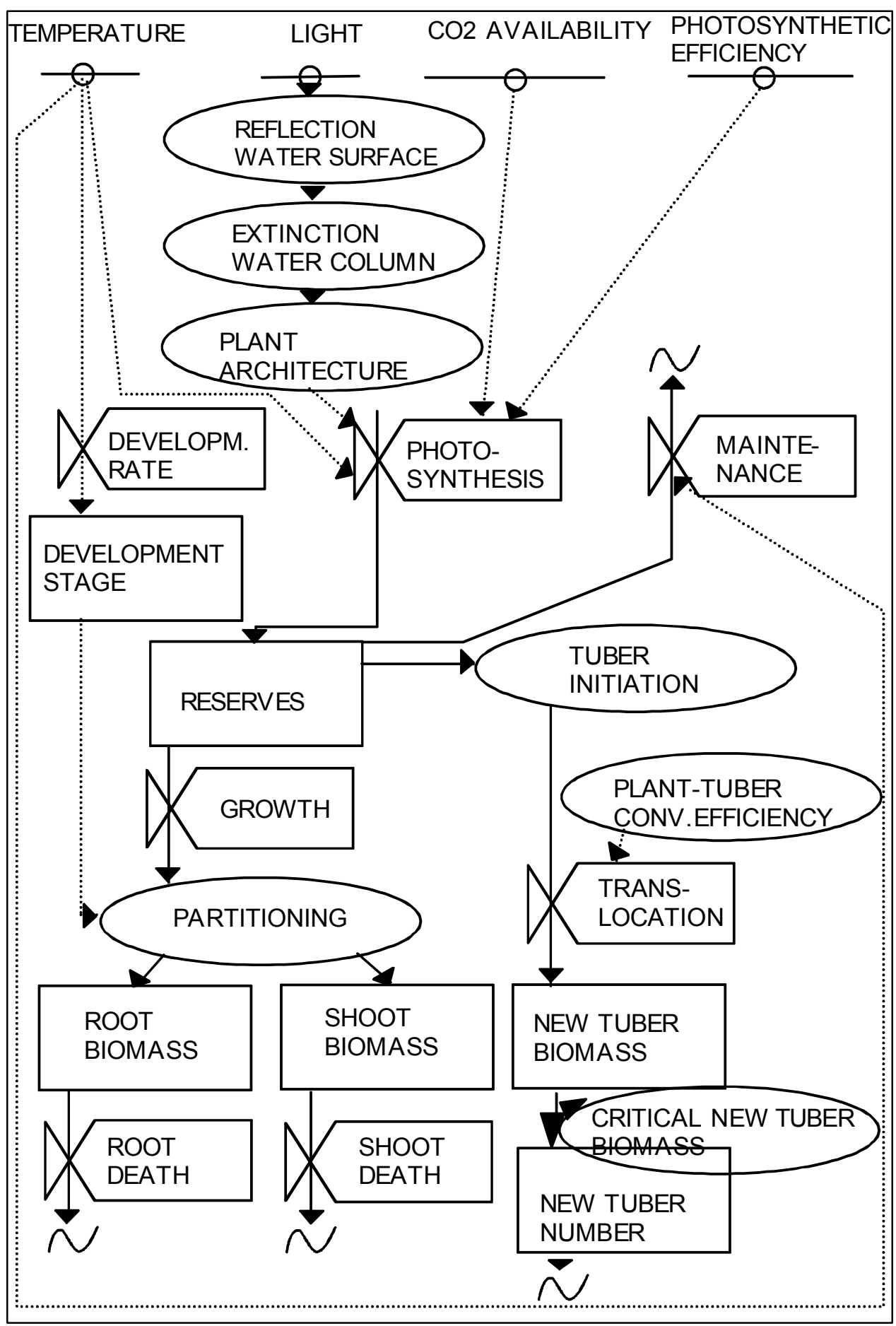

Figure 5. Relational diagram illustrating translocation and senescence following anthesis in sago pondweed

\section{Choice of Parameter Values}

A relatively simple simulation model like POTAM includes parameter values that can be defined with varying certainty. Most parameters have been 
calculated/estimated from published literature (Table 2). Only development rate in relation to $3{ }^{\circ} \mathrm{C}$ day-degree sum and base temperature have been calibrated by running the model. The choice of parameter values has been detailed in the preceding sections of this chapter.

\begin{tabular}{|c|c|c|c|}
\hline \multicolumn{4}{|l|}{$\begin{array}{l}\text { Table } 2 \\
\text { Parameter Values Used in POTAM }\end{array}$} \\
\hline Parameter & Abbreviation & Value & Reference \\
\hline \multicolumn{4}{|c|}{ "Morphology, Phenological Cycle, and Development } \\
\hline First Julian day number & DAYEM & 1 & \\
\hline Base temperature for juvenile plant growth & TBASE & $3^{\circ} \mathrm{C}$ & calibrated \\
\hline Development rate as function of temperature & DVRVT* $^{*}$ & 0.015 & calibrated \\
\hline DVR prior to flowering (DVRVT), DVR subsequently (DVRRT) & DVRRT* & 0.040 & \\
\hline Fraction of total dry matter increase allocated to leaves & FLVT & 0.731 & 1,2 \\
\hline Fraction of total dry matter increase allocated to stems & FSTT & 0.183 & 1,2 \\
\hline Fraction of total dry matter increase allocated to roots & FRTT & 0.086 & 1 \\
\hline \multicolumn{4}{|c|}{ Maximum Biomass and Plant Density } \\
\hline Maximum biomass & & $1,952 \mathrm{~g} \mathrm{DW} \mathrm{m}^{-2}$ & 3 \\
\hline Plant density & NPL & $30 m^{-2}$ & 1,4 \\
\hline \multicolumn{4}{|c|}{ Wintering and Sprouting of Tuber Bank } \\
\hline Initial tuber density & NT & $240 \mathrm{~m}^{-2}$ & 1 \\
\hline Initial dry weight per tuber & INTUB & $0.083 \mathrm{~g} \mathrm{DW}$ tuber $^{-1}$ & 1 \\
\hline Relative tuber death rate (on number basis) & RDTU & $0.026 \mathrm{~d}^{-1}$ & 5 \\
\hline \multicolumn{4}{|c|}{ Initial Growth of Sprouts } \\
\hline Relative conversion rate of tuber into plant material & ROC & $\begin{array}{l}0.0576 \mathrm{~g} \mathrm{CH}_{2} \mathrm{O} \\
\mathrm{g} \mathrm{DW}^{-1} \mathrm{~d}^{-1}\end{array}$ & 6 \\
\hline Relation coefficient tuber weight-stem length & RCSHST & $12 \mathrm{~m}_{\mathrm{g} \mathrm{DW}} \mathrm{g} \mathrm{DW}^{-1}$ & $6,7,8$ \\
\hline Critical shoot weight per depth layer & CRIFAC & $\begin{array}{l}0.0076 \mathrm{~g} \mathrm{DW}^{-} \\
0.1 \mathrm{~m}^{-1} \text { plant layer } \\
\end{array}$ & 7,8 \\
\hline Survival period for sprouts without net photosynthesis & SURPER & $27 \mathrm{~d}$ & 1 \\
\hline \multicolumn{4}{|c|}{ Light, Photosynthesis, Maintenance, Growth and Assimilate Partitioning } \\
\hline Water type specific light extinction coefficient & $\mathrm{L}$ & $1.07 \mathrm{~m}^{-1}$ & 1 \\
\hline Plant species specific light extinction coefficient & $\mathrm{K}$ & $0.095 \mathrm{~m}^{2} \mathrm{~g} \mathrm{DW}^{-1}$ & 1 \\
\hline Potential $\mathrm{CO}_{2}$ assimilation rate at light saturation for shoot tips & AMX & \begin{tabular}{|l|}
$0.019 \mathrm{~g} \mathrm{CO}_{2}$ \\
$\mathrm{~g} \mathrm{DW}^{-1} \mathrm{~h}^{-1}$ \\
\end{tabular} & 9 \\
\hline Initial light use efficiency for shoot tips & EE & $0.000011{\mathrm{~g} \mathrm{CO} 2 \mathrm{~J}^{-1}}^{-1}$ & 10 \\
\hline $\begin{array}{l}\text { Reduction factor for AMX to account for senescence plant parts over } \\
\text { vertical vegetation axis }\end{array}$ & REDF & 1.0 & user def. \\
\hline Daytime temperature effect on AMX as function of DVS & AMTMPT* $^{*}$ & $0-1$ & 1 \\
\hline Reduction factor to relate $\mathrm{AMX}$ to water $\mathrm{pH}$ & REDAM & 1 & 1 \\
\hline Conversion factor for translocated dry matter into $\mathrm{CH}_{2} \mathrm{O}$ & CVT & 1.05 & 10 \\
\hline Dry matter allocation to each plant layer & DMPC* $^{*}$ & $0-1$ & 1 \\
\hline Thickness per plant layer & $\mathrm{TL}$ & $0.1 \mathrm{~m}$ & 11 \\
\hline Water depth & DEPTH & $1.3 \mathrm{~m}$ & user def. \\
\hline Daily water temperature (field site) & WTMPT &,$-{ }^{\circ} \mathrm{C}$ & user def. \\
\hline Total live dry weight measured (field site) & TGWMT &,$- \mathrm{g} \mathrm{DM} \mathrm{m}^{-2}$ & user def. \\
\hline
\end{tabular}




\begin{tabular}{|c|c|c|c|}
\hline \multicolumn{4}{|l|}{ Table 2 (Concluded) } \\
\hline Parameter & Abbreviation & Value & Reference \\
\hline \multicolumn{4}{|c|}{ Induction and Formation of New Tubers } \\
\hline Translocation (part of net photosynthetic rate) & RTR & 0.19 & 1,12 \\
\hline Tuber number concurrently initiated per plant & NINTUB & 8 plant $^{-1}$ & 1,8 \\
\hline Critical tuber weight & TWCTUB & $19.92 \mathrm{~g} \mathrm{DW} \mathrm{m}^{-2}$ & 1,4 \\
\hline Tuber density measured (field site) & NTMT & $440 \mathrm{~m}^{-2}$ & 4 \\
\hline \multicolumn{4}{|c|}{ Flowering and Senescence } \\
\hline Relative death rate of leaves (on DW basis; $Q_{10}=2$ ) & RDRT & $0.047 \mathrm{~d}^{-1}$ & 1 \\
\hline Relative death rate of stems and roots (on DW basis; $Q_{10}=2$ ) & RDST & $0.047 \mathrm{~d}^{-1}$ & 1 \\
\hline \multicolumn{4}{|c|}{$\begin{array}{ll} & \text { Harvesting } \\
\end{array}$} \\
\hline Harvesting & HAR & 0 or 1 & user def. \\
\hline Harvesting day number & HARDAY & $1-365$ & user def. \\
\hline Harvesting depth (measured from water surface; $1-5 \mathrm{~m}$ ) & HARDEP & $0.1 \mathrm{~m}<\mathrm{DEPTH}$ & user def. \\
\hline
\end{tabular}




\section{Performance Tests}

\section{Simulated and Measured Behavior of a Sago Pondweed Community in the Western Canal near Zandvoort, The Netherlands}

\section{Nominal run}

The seasonal changes in biomass of plant shoots and roots and of the tuber bank as simulated by POTAM are shown in Figure 6. Simulated plant biomass compared well with average plant biomass measured in the Western Canal near Zandvoort, The Netherlands (Appendix C). Plant biomass reached its maximum 13 days later, and peak biomass was somewhat higher in the simulated than in the measured plant community, notably 101.9 versus $78.5 \mathrm{~g} \mathrm{DW} \mathrm{m}^{-2}$. However, the simulated biomass higher than measured biomass may be due to the use of air temperatures instead of the measured water temperatures used as input for this nominal run. Air temperatures with a lag period of 7 days (default) were used because the temperature of the water surrounding the majority of the plant shoots in summer was closer to the temperature of the air than to the temperature of the water filling the canals via upward seepage. Another explanation may be that actual maximum plant biomass occurred at the end of August, as found for the 2.5-m depth class (Appendix C); but since biomass was measured only once a month, the actual peak was missed.

Simulated transport of carbohydrates was substantial in the beginning of the growth season when upward carbohydrate remobilization from the tubers supports initial sprouting, but far higher after flowering when downward carbohydrate translocation from plant organs supports the filling of the tubers (Figure 7). Carbohydrate transport could be in the same range as net assimilation at the beginning and end of the growth season (Figures 7 and 8). Maintenance respiration was usually considerably lower than assimilation but could be in the same range of translocation just after flowering (Figure 8).

Running the model with 24-hr averaged air temperatures and a lag period of 7 days instead of with measured water temperatures as forcing variables yielded far higher assimilation (Figure 9) and plant biomass values than yielded by model runs on water temperatures. This can be explained by the fact that water temperatures in the Western Canal were far lower than air temperatures in summer, because of the large inflow of groundwater (Appendix C). In the 
experience of the authors, a lag period of 7 days between model daily air and measured temperatures usually describes this relationship well for shallow water bodies, up to 5-6 m deep, without large inflows of groundwater. It has to be cautioned that the relationship between the temperatures of air and water body may differ, since temperatures within each water body are influenced by catchment morphometry, wind speed, fetch, mixing processes, and upward seepage. This example illustrates the usefulness of inclusion of both temperature options in the model, facilitating its operation by users who do not possess a full data set of water temperatures for the water body for which they desire to run the model.

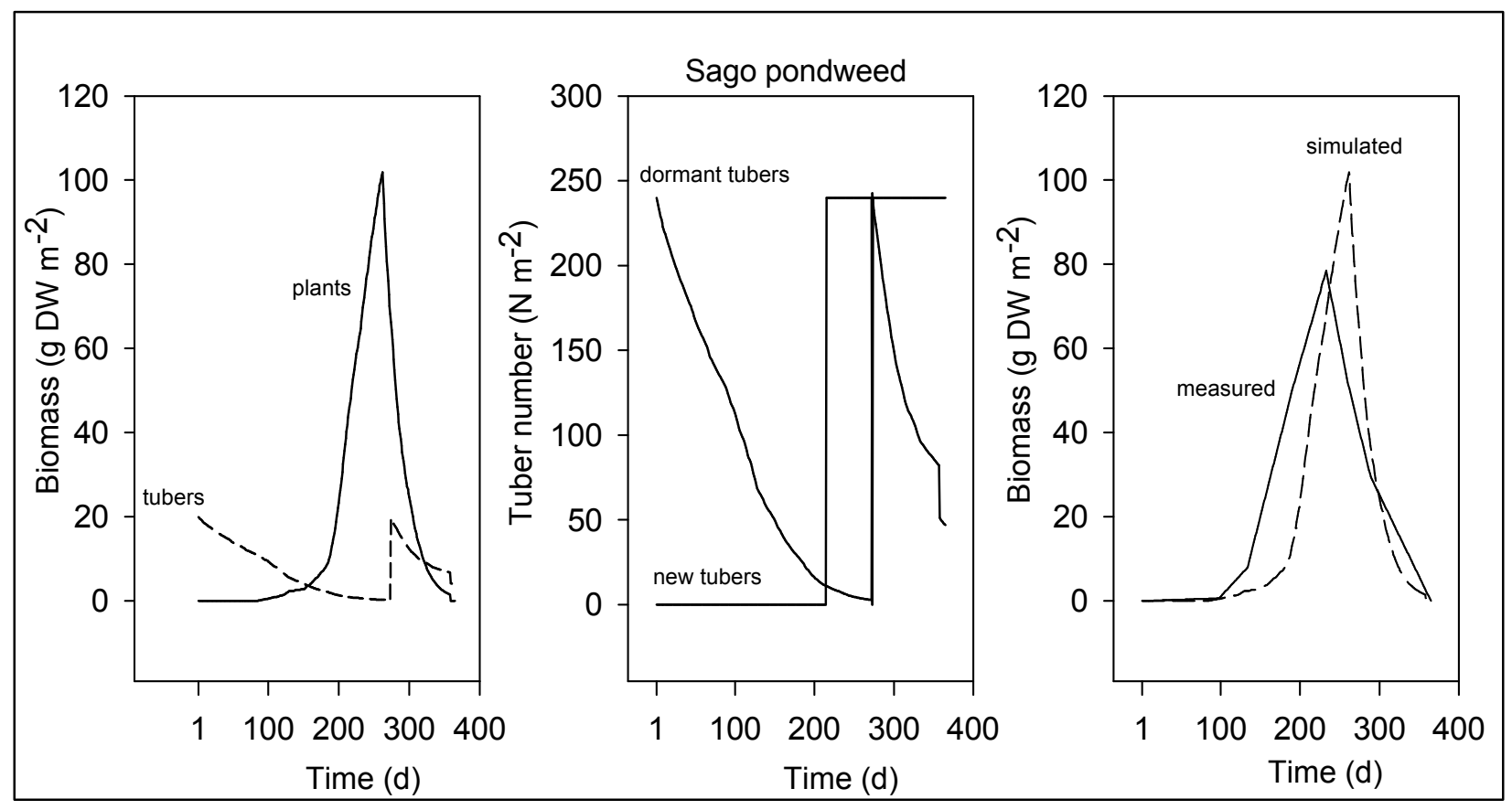

Figure 6. Simulated biomass of plants, dormant and new tuber numbers, and measured plant biomass of a sago pondweed community in the Western Canal near Zandvoort, The Netherlands. Nominal run. Field data from Appendix C; climatological data 1987, De Bilt, The Netherlands (longitude $05^{\circ} 11^{\prime} \mathrm{E}$, latitude $52^{\circ} 06^{\prime} \mathrm{N}$ ); water depth $1.3 \mathrm{~m}$; light extinction coefficient $1.07 \mathrm{~m}^{-1}$

Running the model for the same canal and year, but with both plants and tubers initially present, showed that peak plant biomass was greatly increased but no tuber class was finished (Figure 10b). The large increase in peak biomass is due to the ability of the plant community to fully capture the high spring irradiance at this latitude of $52^{\circ} \mathrm{N}$, which they cannot without wintering shoots. However, since maintenance respiration increased proportionally to plant biomass and light extinction due to self-shading was high, carbohydrate reserves invested in tubers were insufficient to finalize a large sized tuber class; consequently, such plant population would become extinct the next year. Thus, wintering shoots would not provide a distinct advantage for this plant species in a temperate climate. A simulation started with initial plant biomass but from a smaller tuber size/concurrently initiated tuber number combination (a $0.07 \mathrm{~g} \mathrm{DW}$ and 6 tubers 
per plant) yielded a far higher peak plant biomass and 50 percent reduced tuber numbers compared to the values measured in the Western Canal (Appendix C).

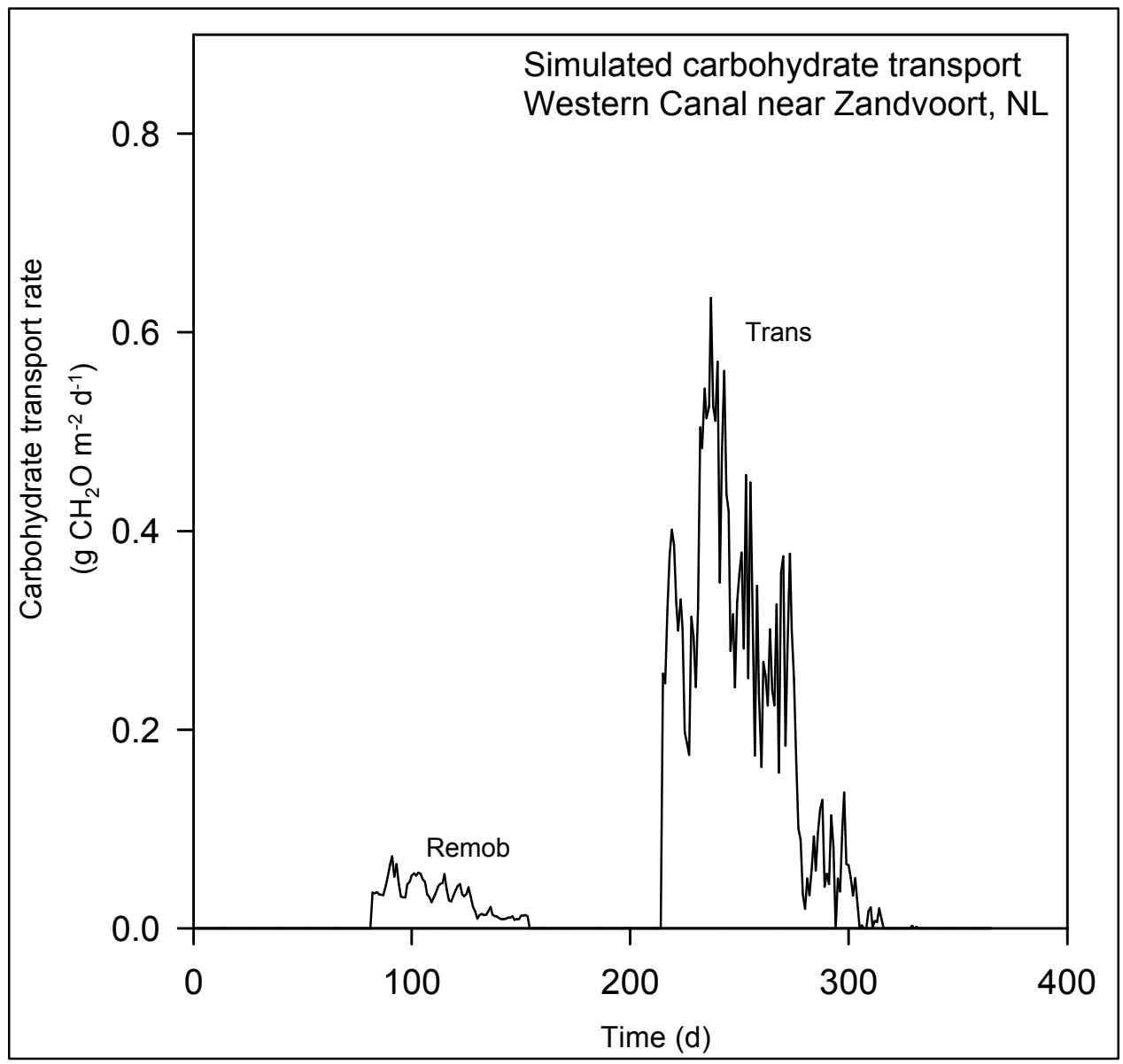

Figure 7. Simulated behavior of carbohydrate flow through plant compartments of a sago pondweed community in the Western Canal near Zandvoort, The Netherlands (carbohydrate remobilization and upward transport from the tubers is used for initial growth of plants. Downward carbohydrate translocation into tubers occurs during anthesis and senescence (initial biomass and climatological data as in nominal run))

\section{Effects of differences in leaf surface:dry weight ratio}

A large range of leaf surface area:dry weight ratios (K-value) in sago pondweed has been found. All K-values were measured in sago pondweed populations in temperate climates, varying from $0.0183 \mathrm{~m}^{2} \mathrm{~g} \mathrm{DW}^{-1}$ by Sher-Kaul et al. (1995) in populations in mesotrophic Lake Geneva, Switzerland, to $0.02 \mathrm{~m}^{2}$ $\mathrm{g} \mathrm{DW}^{-1}$ by Westlake (1964) in British calcareous stream populations, to $0.095 \mathrm{~m}^{2}$ $\mathrm{g} \mathrm{AFDW}^{-1}$ in a population in the eutrophic Western Canal, The Netherlands (Appendix C). It is possible that sago pondweed populations in a tropical climate may have thinner leaves, with a concomitant lower K-value, as was found in american wildcelery in Australia $\left(0.051 \mathrm{~m}^{2} \mathrm{~g} \mathrm{DW}^{-1}\right.$; Blanch et al. 1998) and in 
Eurasian watermilfoil (Best and Boyd 1999), but to the knowledge of the authors no such K-value has been published yet.

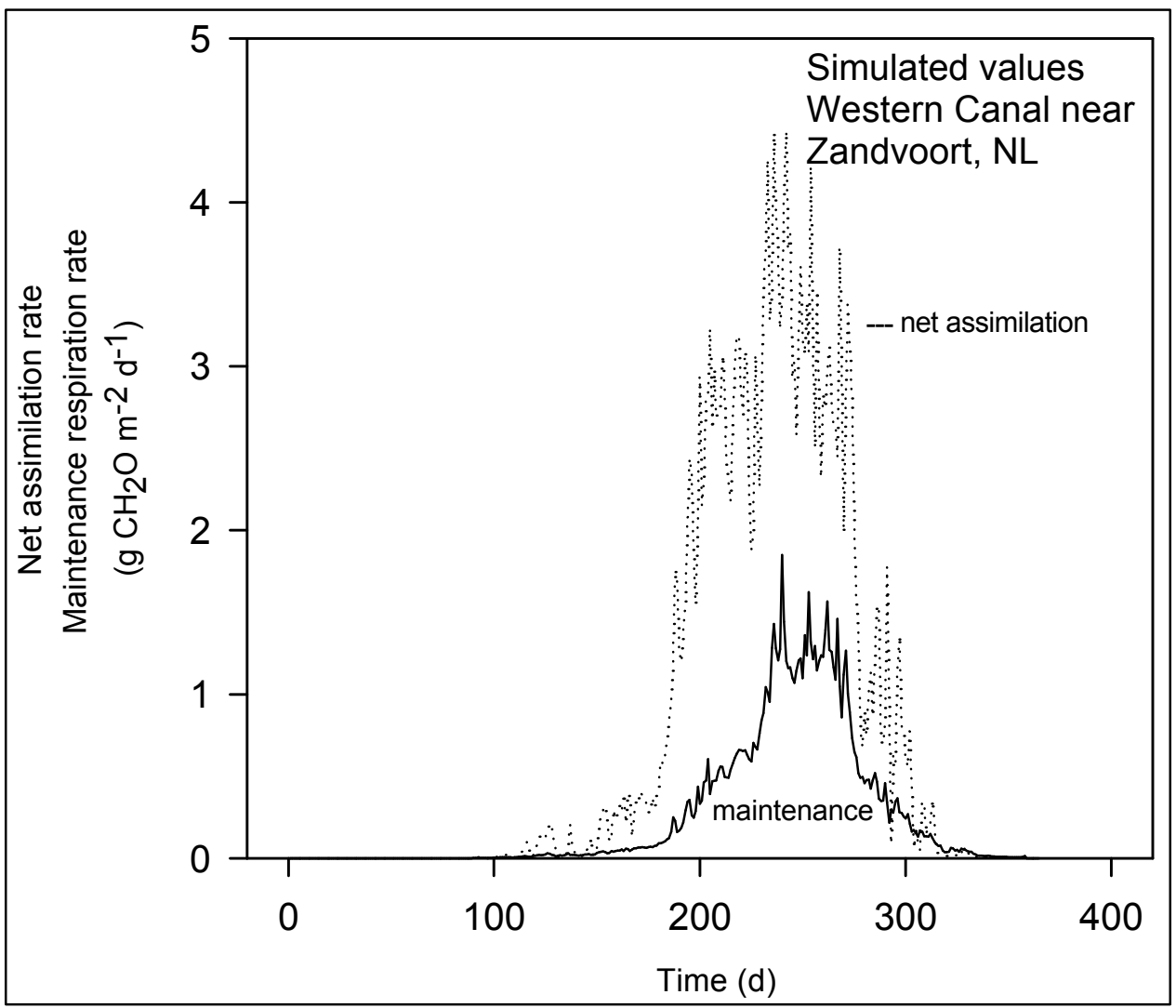

Figure 8. Simulated rates of daily net assimilation and maintenance respiration of a sago pondweed community in the Western Canal near Zandvoort, The Netherlands (initial plant parameter values as in nominal run)

Simulations indicated that peak plant biomass increased with decreasing Kvalue to a small extent but not proportionally, and that tuber production was similar (Figure 11). A sago pondweed community starting from the same tuber bank as the nominal one and characterized by a K-value of $0.020 \mathrm{~m}^{2} \mathrm{~g} \mathrm{DW}^{-1}$ (compared to the nominal value of $0.095 \mathrm{~m}^{2} \mathrm{~g} \mathrm{DW}^{-1}$ ) would produce about 13 percent more biomass than a nominal community. Plant biomass and tuber production were similar for communities with $\mathrm{K}$-values of 0.020 and $0.0183 \mathrm{~m}^{2} \mathrm{~g}$ $\mathrm{DW}^{-1}$ (Figure 11).

\section{Effects of differences in tuber bank density and anchorage depth}

Sago pondweed has shown the ability to colonize shallow aquatic areas rapidly because it may form various diaspores, among which tubers are the most numerous (Yeo 1965). To explore the potential for rapid population establishment from only a few tubers, the model was run from an initial tuber bank density of 10 tubers $\mathrm{m}^{-2}$ under nominal climatological conditions at a higher than nominal anchorage depth, i.e., $2.5 \mathrm{~m}$. It turned out that under these conditions substantial plant biomass was formed and that one more tuber class was finished than in a nominal population (Figure12B versus Figure12A), probably because less self- 
shading occurred. However, a population starting from a nominal tuber bank density of 240 tubers $\mathrm{m}^{-2}$ at a greater anchorage depth of $5 \mathrm{~m}$ would become extinct within a year (Figure12C), due to the greater light extinction within the higher water column. Tuber size turned out to be more important than tuber bank density, since plantlets emerging from smaller tubers tended to die before attaining a self-supporting carbon-gain level.

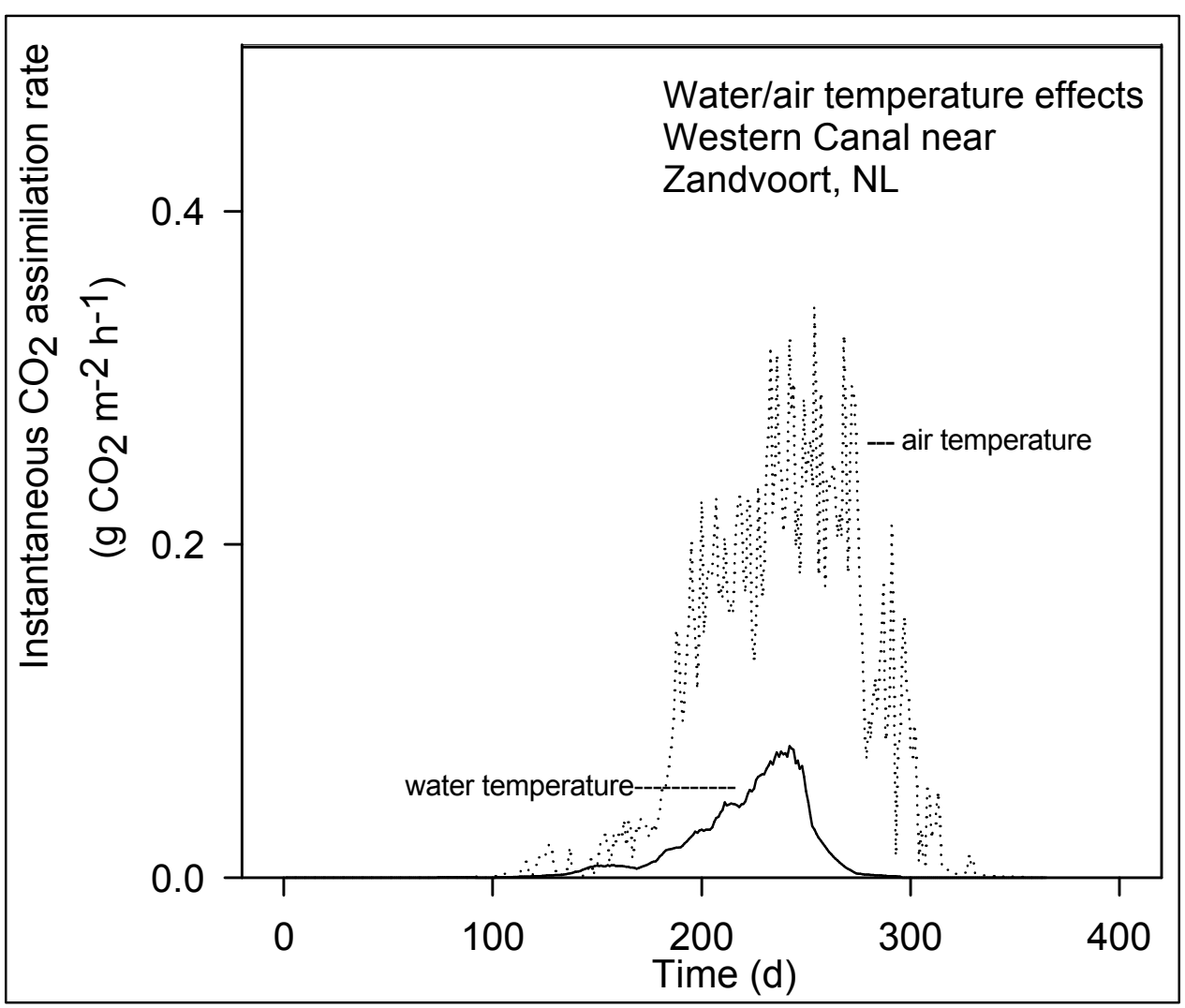

Figure 9. Simulated photosynthetic rates of a sago pondweed community in the Western Canal near Zandvoort, The Netherlands, with water or air temperatures as input (initial plant parameter values as in nominal run)

\section{Simulated and Measured Behavior of a Sago Pondweed Community in Lake Veluwe, The Netherlands, in Two Consecutive Years with Greatly Different Turbidities}

Lake Veluwe, located in the center of The Netherlands, is a man-made, shallow, wind-exposed, eutrophic lake in which remnants of sago pondweed populations remained at the end of the 1970s (Bick and Van Schaik 1980). The decline in aquatic macrophyte coverage area was attributed to increased turbidity due to eutrophication, and management strategies were sought to reverse this decline. Management including regularly flushing the lake and a reduction in external phosphorus loading resulted in a more transparent water column and a slow increase in the area colonized by sago pondweed. Because this management 
scenario did not lead to a full recovery of the sago pondweed population, several studies have been undertaken to quantify the relationship between light availability within the water column and the production of plant biomass and tubers in this lake. Field data on plant and tuber biomass, and on local water transparency generated by the studies mentioned previously have been used to validate the data simulated using POTAM (Van Dijk et al. 1992; Van Dijk and Achterberg 1992).

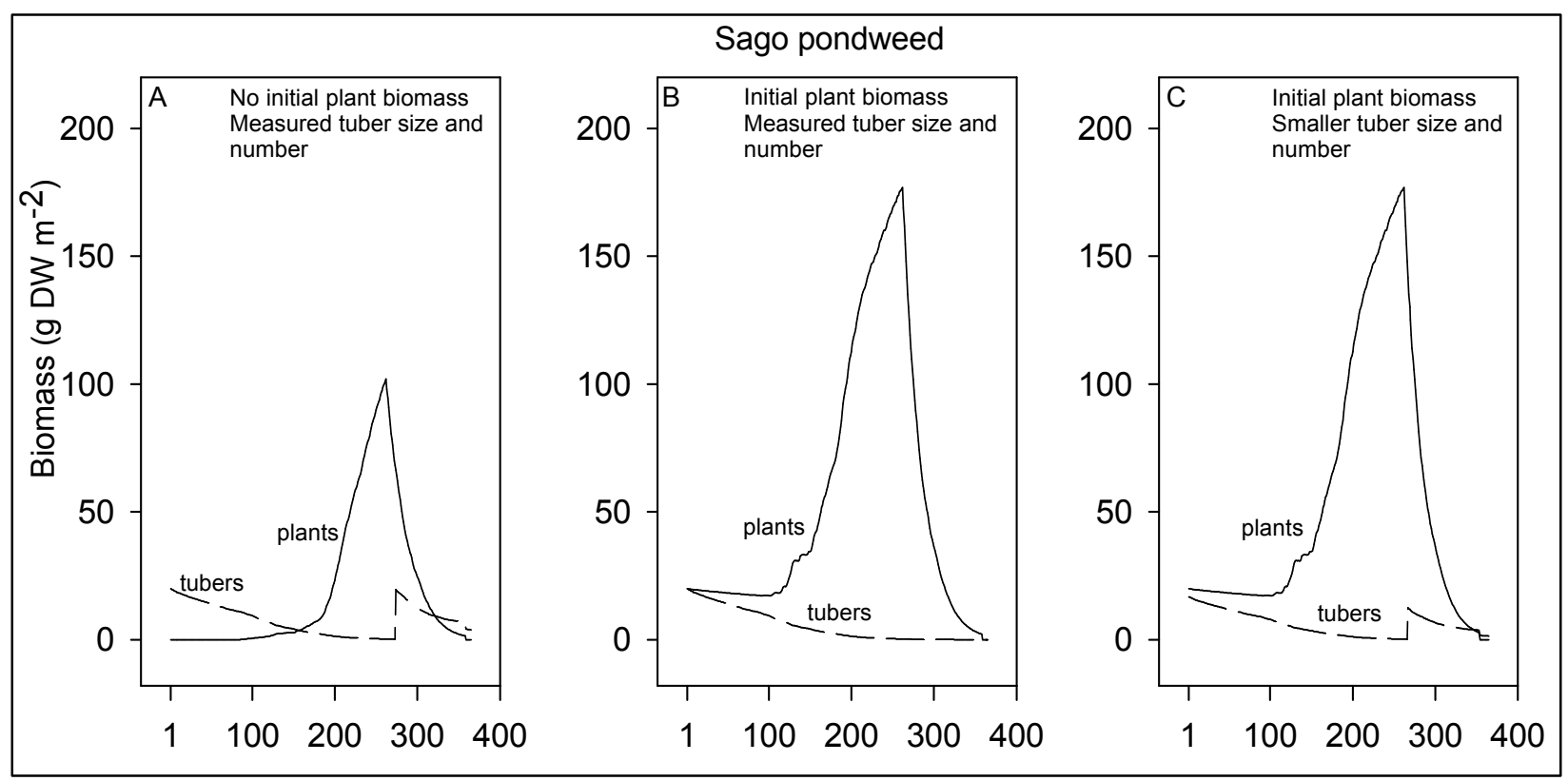

Figure 10. Simulated biomass of plants and tubers of a sago pondweed community in the Western Canal near Zandvoort, The Netherlands, started from different initial biomass conditions, but run in the same environmental and climatological nominal conditions: (A) Plant biomass 0; tuber size $0.083 \mathrm{~g} \mathrm{DW}$; tuber bank $240 \mathrm{~m}^{-2}$, (B) Plant biomass $20 \mathrm{~g} \mathrm{DW} \mathrm{m}^{-2}$; tuber size $0.083 \mathrm{~g} \mathrm{DW}$; tuber bank density $240 \mathrm{~m}^{-2}$; (C) Plant biomass $20 \mathrm{~g} \mathrm{DW} \mathrm{m}^{-2}$; tuber size $0.070 \mathrm{~g} \mathrm{DW}$; tuber bank density $240 \mathrm{~m}^{-2}$

The model was run for two consecutive years greatly differing in turbidity, i.e., 1986 and 1987, using as initial values the measured tuber bank densities and predominant tuber sizes. Model results indicated that a higher plant biomass but lower tuber class number (four classes in 1986 versus seven classes in 1987) would be expected in 1986 than in 1987, with plant biomass and newly produced tuber densities similar to measured ones (Figure 13). The timing at which the simulated maxima in plant biomass and tuber density occurred coincided with the measured values in 1986, but were delayed in 1987 (Figure 13). This example illustrates that although intuitively it would be expected that a larger peak plant biomass would lead to a higher tuber density, it is possible that in reality fewer tubers are formed since the latter process does not depend only on plant biomass but also on the critical combination of day length and temperature. 


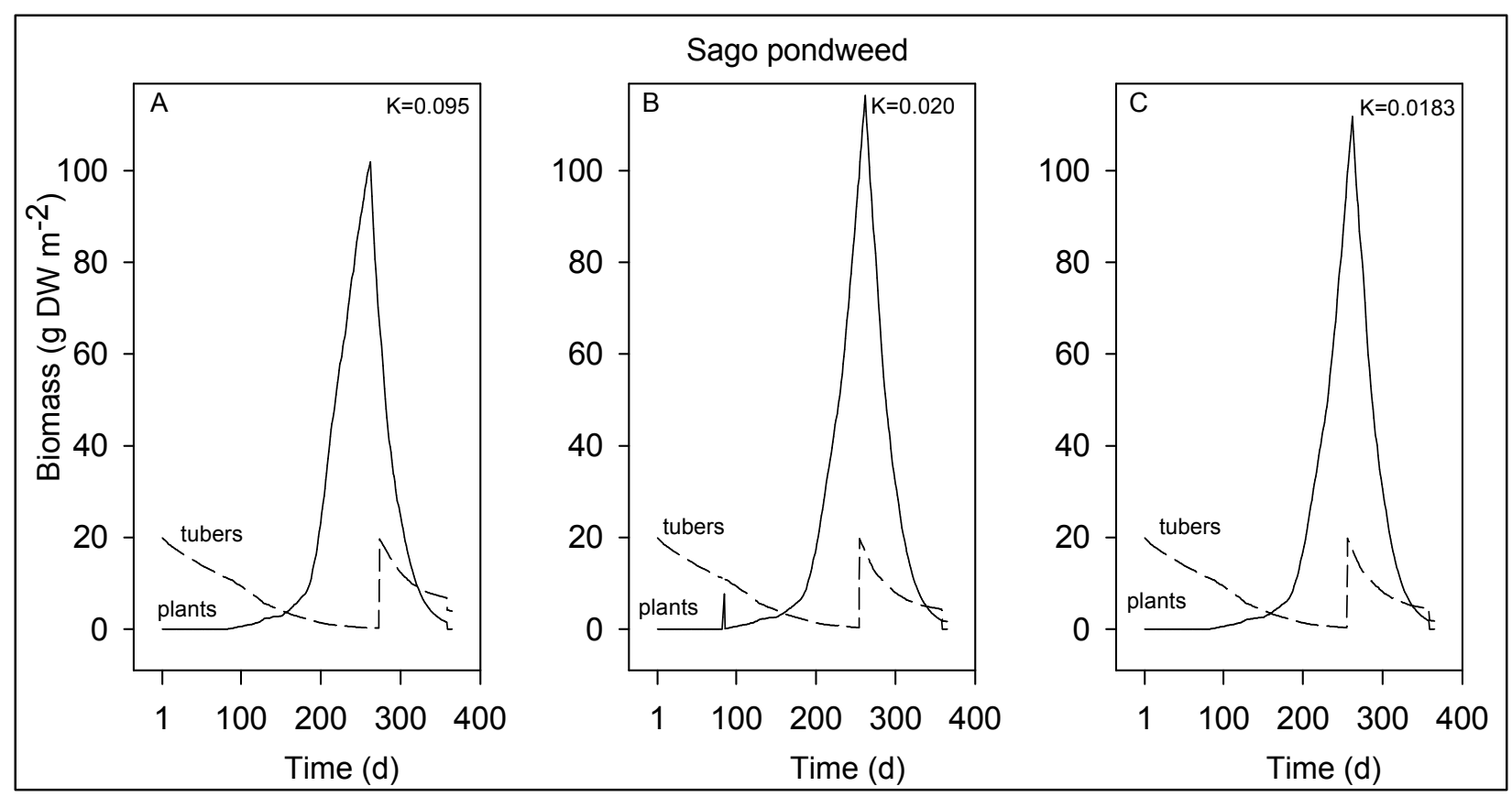

Figure 11. Simulated biomass of plants and tubers of a sago pondweed community in the Western Canal near Zandvoort, The Netherlands, started from identical nominal initial biomass conditions, except for the K-value (climatological data as in nominal run). K-values of (A) $0.095 \mathrm{~m}^{2} \mathrm{~g}$ $\mathrm{AFDW}^{-1}$ (Appendix C); (B) $0.020 \mathrm{~m}^{2} \mathrm{~g} \mathrm{DW}^{-1}$; Westlake (1964; as used by Hootsmans 1991) ; (C) $0.0183 \mathrm{~m}^{2} \mathrm{~g} \mathrm{DW}^{-1}$; Sher-Kaul et al. (1995)

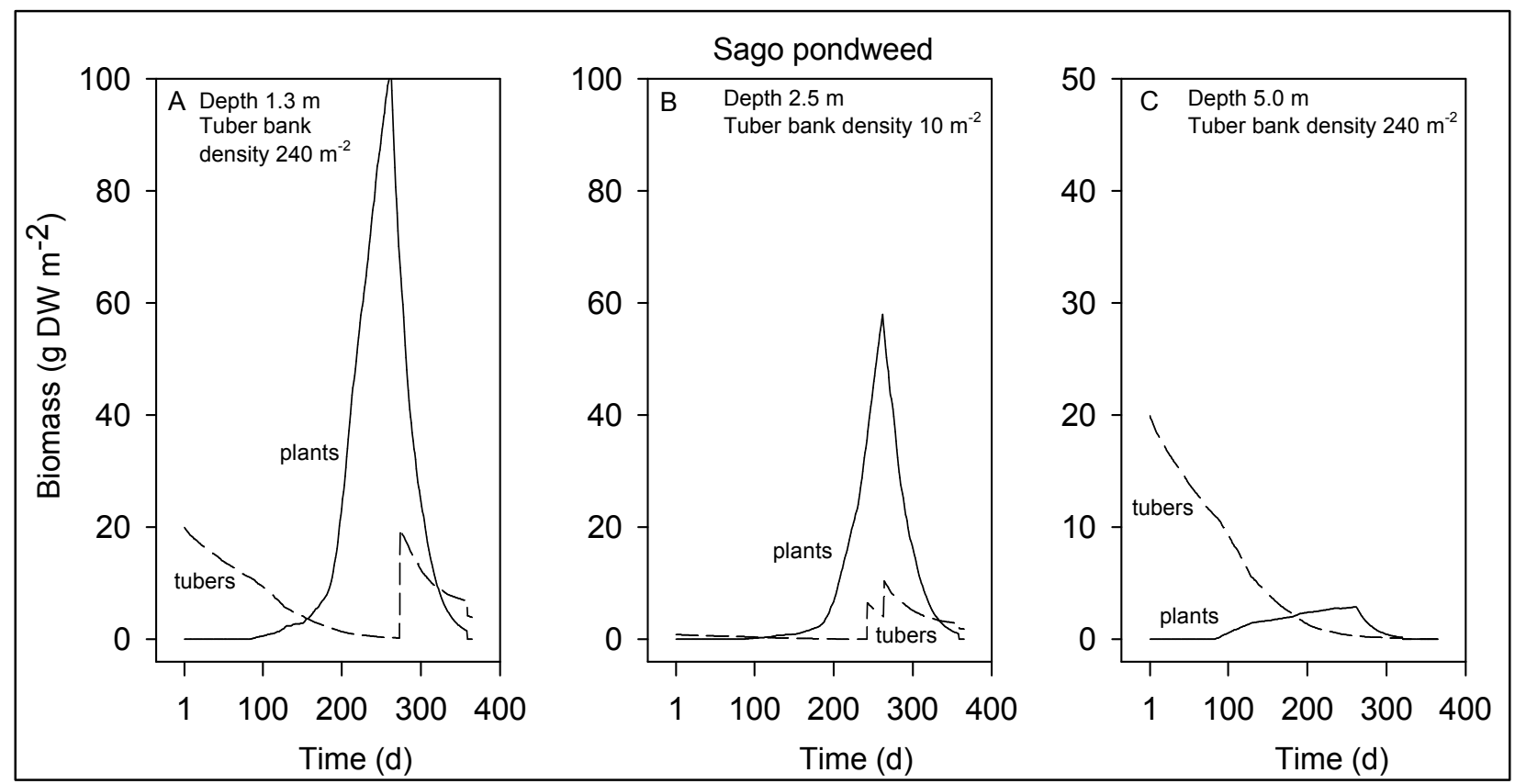

Figure 12. Simulated biomass of plants and dormant tubers of a sago pondweed community in the Western Canal near Zandvoort, The Netherlands, started from nominal initial biomass data differing in tuber bank density and anchorage depth (climatological data as in nominal run). (A) Tuber size $0.083 \mathrm{~g} \mathrm{DW}$, tuber bank density $240 \mathrm{~m}^{-2}$; rooting depth $1.3 \mathrm{~m}$; (B) Tuber size $0.083 \mathrm{~g} \mathrm{DW}$, tuber bank density $10 \mathrm{~m}^{-2}$; rooting depth $2.5 \mathrm{~m}$; (C) Tuber size $0.083 \mathrm{~g} \mathrm{DW}$, tuber bank density $240 \mathrm{~m}^{-2}$; rooting depth $5.0 \mathrm{~m}$ 


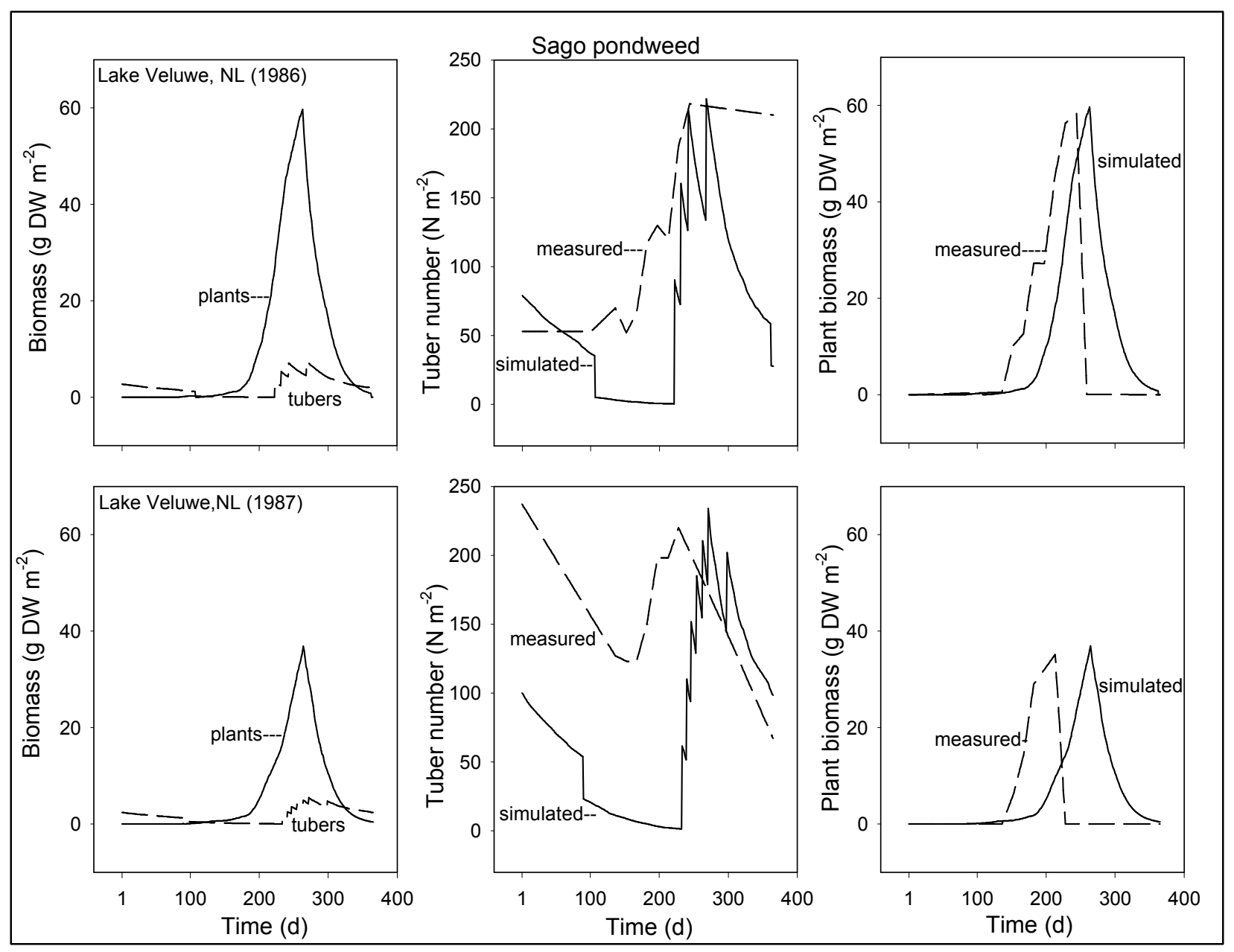

Figure 13. Simulated and measured biomass of plants and tubers of sago pondweed in Lake Veluwe, The Netherlands, during two successive years differing in water transparency. Initial values on tuber size and tuber bank density from Van Dijk et al. 1992; 1986, initial tuber weight $0.034 \mathrm{~g}$ dry weight, tuber bank density $79 \mathrm{~m}^{-2}$, water depth $0.5 \mathrm{~m} ; 1987$, initial tuber weight $0.024 \mathrm{~g}$ dry weight, tuber bank density $100 \mathrm{~m}^{-2}$, water depth $0.5 \mathrm{~m}$. Light extinction coefficient from Van Dijk and Achterberg 1992; 1986, average May-September $2.58 \mathrm{~m}^{-1} ; 1987$, average $4.30 \mathrm{~m}^{-1}$. Climatological data 1986, 1987, De Bilt, The Netherlands (longitude $05^{\circ} 11^{\prime} \mathrm{E}$, latitude $52^{\circ} 06^{\prime} \mathrm{N}$ )

\section{Simulated and Measured Behavior of a Sago Pondweed Community at Other Latitudes}

To investigate whether the model is able to simulate the behavior of a sago pondweed community at other sites besides the nominal one, runs were made for two other sites, one more western, the Byrnes Canal, California, and one more southern, tropical Lake Ramgarh, India.

A simulation was performed of a sago pondweed community in the Byrnes Canal, California, starting from site-specific community, water depth, transparency, and climatological data. For this site, plant community-specific data included the following: 
a. Initial plant biomass: absent.

b. Tuber size: $0.025 \mathrm{~g} \mathrm{DW}$.

c. Concurrently initiated tuber number: 3 plant $^{-1}$.

d. Tuber bank density: $700 \mathrm{~m}^{-2}$.

The following environmental data were included:

a. Water depth: $0.2 \mathrm{~m}$.

b. Light extinction coefficient: $0.4 \mathrm{~m}^{-1}$.

In these conditions, simulated plant biomass showed a maximum of $130 \mathrm{~g}$ DW $\mathrm{m}^{-2}$ using the nominal self-shading coefficient (KT) of $0.095 \mathrm{~m}^{2} \mathrm{~g} \mathrm{DW}^{-1}$, but a maximum close to the measured biomass of $175 \mathrm{~g} \mathrm{DW} \mathrm{m}^{-2}$ at a lower selfshading coefficient of $0.0183 \mathrm{~m}^{2} \mathrm{~g} \mathrm{DW}^{-1}$ (as reported by Sher-Kaul et al., 1995, for clear Lake Geneva. In both simulations many tuber classes were finished, giving rise to extremely high tuber densities just as found in situ (Figure 14B; Spencer 1990, unpublished results ${ }^{1}$ ).

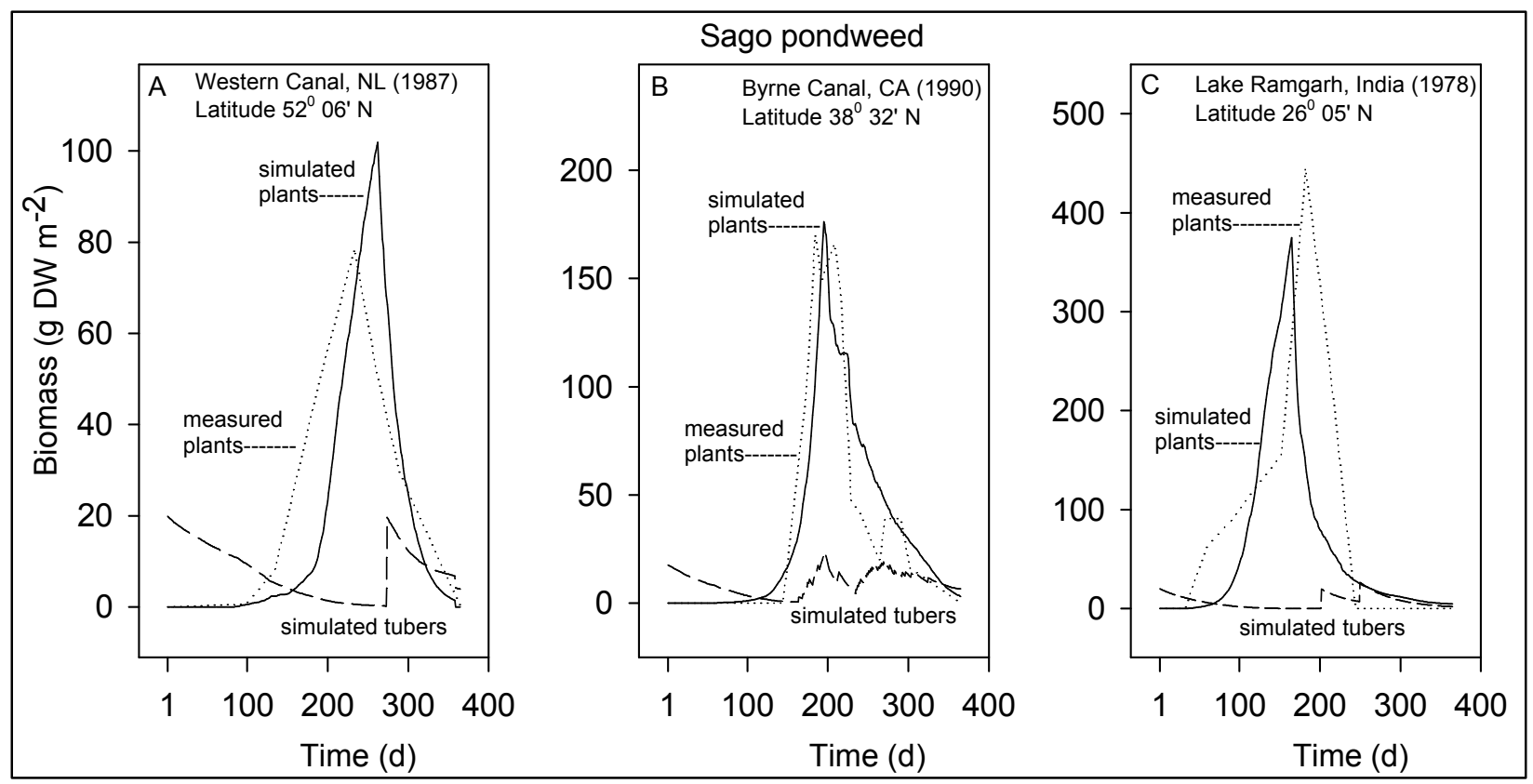

Figure 14. Simulated biomass of plants and tubers of a sago pondweed community at sites differing in latitude. (A) The Western Canal near Zandvoort, The Netherlands (longitude 05 $11^{\prime}$ E, latitude $52^{\circ} 06^{\prime} \mathrm{N}$; tuber size $0.083 \mathrm{~g} \mathrm{DW}$, tuber bank density $240 \mathrm{~m}^{-2}$; water depth $1.3 \mathrm{~m}$; light extinction coefficient $1.07 \mathrm{~m}^{-1}$; climatological data 1987; validation data 1987 (Appendix C). (B) Byrne Canal, CA (longitude $121^{\circ} 47^{\prime} \mathrm{W}$, latitude $38^{\circ} 32^{\prime} \mathrm{N}$; tuber size $0.025 \mathrm{~g} \mathrm{DW}$, tuber bank density $700 \mathrm{~m}^{-2}$; K-value $0.0183 \mathrm{~m}^{2} \mathrm{~g} \mathrm{DW}^{-1}$; water depth $0.2 \mathrm{~m}$; light extinction coefficient $0.4 \mathrm{~m}^{-1}$; climatological data 1990; validation data 1990, Spencer ${ }^{1}$ ). (C) Lake Ramgarh, India (longitude $83^{\circ} 26^{\prime} \mathrm{E}$, latitude $26^{\circ} 05^{\prime} \mathrm{N}$; tuber size $0.083 \mathrm{~g} \mathrm{DW}$, tuber bank density $240 \mathrm{~m}^{-2}$; K-value $0.0183 \mathrm{~m}^{2} \mathrm{~g} \mathrm{DW}^{-1}$; water depth $1.3 \mathrm{~m}$; light extinction coefficient 1.07 $\mathrm{m}^{-1}$; climatological data Patancheru, India, 1978 (Iongitude $78^{\circ} 28^{\prime} \mathrm{E}$, latitude $17^{\circ} 27^{\prime} \mathrm{N}$ ); validation data 1968, Sahai and Sinha (1973)

\footnotetext{
${ }^{1}$ Dr. David Spencer, U.S. Department of Agriculture - Agricultural Research Service, University of California, Davis, December 2001.
} 
Another simulation was performed of a sago pondweed community in Lake Ramgarh, India, starting from a nominal community, water depth, and transparency, with climatological data pertaining to Patancheru, India. For this site, plant community-specific data included the following:

a. No initial plant biomass.

b. Tuber size: $0.083 \mathrm{~g} \mathrm{DW}$.

c. Concurrently initiated tuber number: 8 plant $^{-1}$.

d. A tuber bank density of $240 \mathrm{~m}^{-2}$.

In these conditions simulated plant biomass was high, maximally $375 \mathrm{~g} \mathrm{DW}$ $\mathrm{m}^{-2}$, and only two tuber classes could be finished within a year. Tuber weights and numbers of the Lake Ramgarh community were not published, so comparison between simulated and measured tuber data is not possible. However, simulated maximum plant biomass in this case was in the same order of magnitude as the measured peak biomass of $445 \mathrm{~g} \mathrm{DW} \mathrm{m}^{-2}$ (Figure 14C).

Comparison of biomass production characteristics in the various climatological conditions (Figure 14) indicates that in a temperate climate generally less biomass is produced, but investment in vegetative reproduction is relatively higher than in a tropical climate. The criteria for tuber formation, (a) timed just after flowering, (b) day length between 12 and $16 \mathrm{hr}$, and (c) temperature between 5.5 and $25{ }^{\circ} \mathrm{C}$, were met for long continuous periods in The Netherlands and California, but only occasionally in India because the temperature usually exceeded the critical range. In The Netherlands tubers could be initiated from day 215 to 250 at relatively moderate irradiance, allowing only one tuber class to be finished (Figure 15A); in California tubers could be initiated from day 161 to 250 at far higher irradiance, giving rise to many tuber classes (Figure15B); in India tubers could be initiated from day 150 to 220 so that only two tuber classes might be finished (Figure 15C). The extremely limited window for tuber formation in tropical regions was confirmed recently by Pilon (1999), who reported that the number of tubers formed per plant increases from around 0 at a latitude of $25^{\circ} \mathrm{N}$ to 8 at $68{ }^{\circ} \mathrm{N}$, but predominant tuber size decreases from 0.022 to $0.006 \mathrm{~g} \mathrm{DW}$ tuber ${ }^{-1}$. Although the latter characteristics were suggested at first to have a genetic basis, it was reported later on that they may be environmentally regulated (Pilon and Santamaria 2002). This example illustrates the usefulness of inclusion of phenology tied to degree-day sum in the model, allowing it to perform simulations for different sites and climates. This feature facilitates its operation by users who do not possess a full data set on plant characteristics and environmental variables for the water body for which they desire to run the model.

The tentative difference in importance of sexual reproduction between climates cannot be explored with the current version of the model, since sexual reproduction has not been included. 


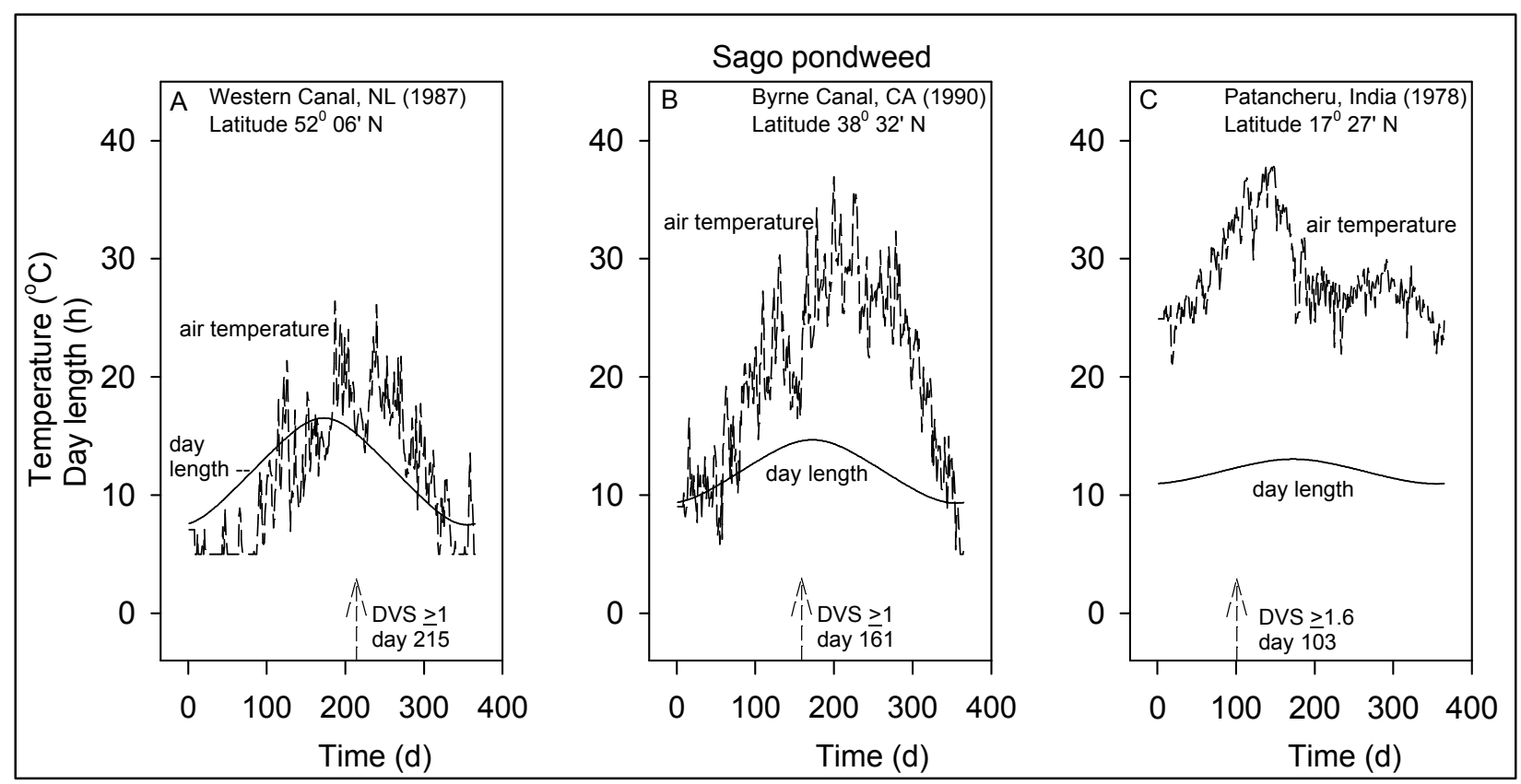

Figure 15. Developmental stage and Julian day number at which tuber formation is initiated in a sago pondweed community at sites differing in latitude, in relation to day length and temperature.

(A) The Western Canal near Zandvoort, The Netherlands (longitude $05^{\circ} 11^{\prime} \mathrm{E}$, latitude $52^{\circ} 06^{\prime} \mathrm{N}$; climatological data 198). (B) Byrne Canal, CA (longitude $121^{\circ} 47^{\prime} \mathrm{W}$, latitude $38^{\circ} 32^{\prime} \mathrm{N}$; climatological data 1990). (C) Patancheru, India 1978 (longitude 78²8' E, latitude $17^{\circ} 27^{\prime} \mathrm{N}$; climatological data 1978)

\section{Historical and Simulated Behavior of a Sago Pondweed Community in a Riverine Environment Subject to Flooding}

Sago pondweed is an important riverine macrophyte that provides food and habitat resources for waterfowl, fish, and invertebrates in the Upper Mississippi River (UMR). Navigation pools along the Mississippi Flyway have historically been used by migrating waterfowl as staging areas in part because of abundant populations of tuber-producing aquatic macrophytes (Bellrose et al. 1983; Korschgen et al. 1988; Korschgen 1989). Declines in the populations of tuberproducing aquatic macrophytes, such as American wildcelery and sago pondweed, have occurred since 1988, and continued through the 1990's (Green 1960; Fischer and Claflin 1992). These declines have been attributed to eutrophication, sediment nutrient depletion, competition by other macrophytes such as Eurasian watermilfoil (Myriophyllum spicatum L.) and American lotus (Nelumbo lutea (Willd.) Pers.) in shallow areas, drought, flooding, and changes in current velocity and wave characteristics as consequences of increased navigation (Rogers 1996). It is desirable to improve management programs aimed at enhancing tuberproducing macrophyte populations, but these programs require an improved understanding of the population dynamics of these plants and factors affecting them. 
Simulations were carried out to evaluate the effects of daily changes in water level during different hydrological years on a typical sago pondweed community in Pool 8 of the UMR. Stage data collected at the dam of Pool 8 were used to document water level fluctuations over a 10-year period, from 1985 to 1994. In this period, 1985 is considered as a normal hydrological year, 1986 as a normal flood year with floods in spring and autumn, 1993 as an abnormal flood year with one flood in summer, and 1988 as a drought year (Figure 16).

The simulations were done starting from a nominal sago pondweed community, site-specific environmental data, and site- and year-specific climatological data. Site-specific environmental data included water depth daily varying as would be experienced by a community at $0.5-\mathrm{m}$ anchorage depth; and a light extinction coefficient ranging from 2.619 to $3.173 \mathrm{~m}^{-1}$ during May to October, and set to $2.0 \mathrm{~m}^{-1}$ the rest of the year (converted via Giesen's relationship from Secchi disk readings (Giesen et al. 1990) correlated with 10-year data on total suspended solids concentrations). Since no historical data on biomass were available, only comparison with presence/absence documentation was possible (Figure 17C).

Running POTAM with nominal initial plant biomass and tuber bank data at a constant $0.5-\mathrm{m}$ water depth with a 10 -year average climate indicated that a peak biomass of $105 \mathrm{~g} \mathrm{DW} \mathrm{m}^{-2}$ was formed, and that two tuber classes would be finished. Under the same conditions, a 2-m depth class would produce $72 \mathrm{~g} \mathrm{DW}$ $\mathrm{m}^{-2}$ and only one tuber class (Figure 17B). Water fluctuations were usually substantial, and it was therefore concluded that calculation of the annual average water depth from nine historical data might yield an erroneous, probably too high, average and that, therefore, the simulated plant biomass would be an underestimate. As expected, more plant biomass ( 20 percent) would be produced, but only one tuber class finished, under a normal water level fluctuation regime in Pool 8, pointing to a tentative positive influence of relatively small water level fluctuations as found in 1985 (Figure 17C). Normal flooding inhibited biomass and tuber production somewhat, but allowed two tuber classes to be finished possibly because the midsummer water levels were somewhat lower than in 1985 (Figure 17D). The relatively small size of this effect was attributed to the fortuitous timing of the high water levels that occurred only in spring and autumn, still allowing the plants to fully benefit from the high summer irradiance at normal water levels. Abnormal flooding, however, reduced the finished number of tuber classes by a factor of 2 in the $0.5-\mathrm{m}$ depth class (Figure 17E), and completely prevented tuber formation in the 1-m depth class (latter data not shown). The harshness of this effect was attributed to the fact that the plants could not fully benefit from the high summer irradiance due to the high summer water levels. The effect of the 1988 drought was surprising. In this year substantial plant biomass could be produced peaking relatively early in the growth season, but tuber formation was inhibited later on - as in the case of abnormal flooding - because (a) water levels were kept relatively high later in summer, possibly as a water conservation measure, causing increased extinction of light within the water column, and (b) temperatures were relatively high, causing increased respiration and senescence. The increased light extinction in the water column may even have been larger in situ than in the simulation, since during droughts not only water levels may change but also extinction within the water column may increase by 


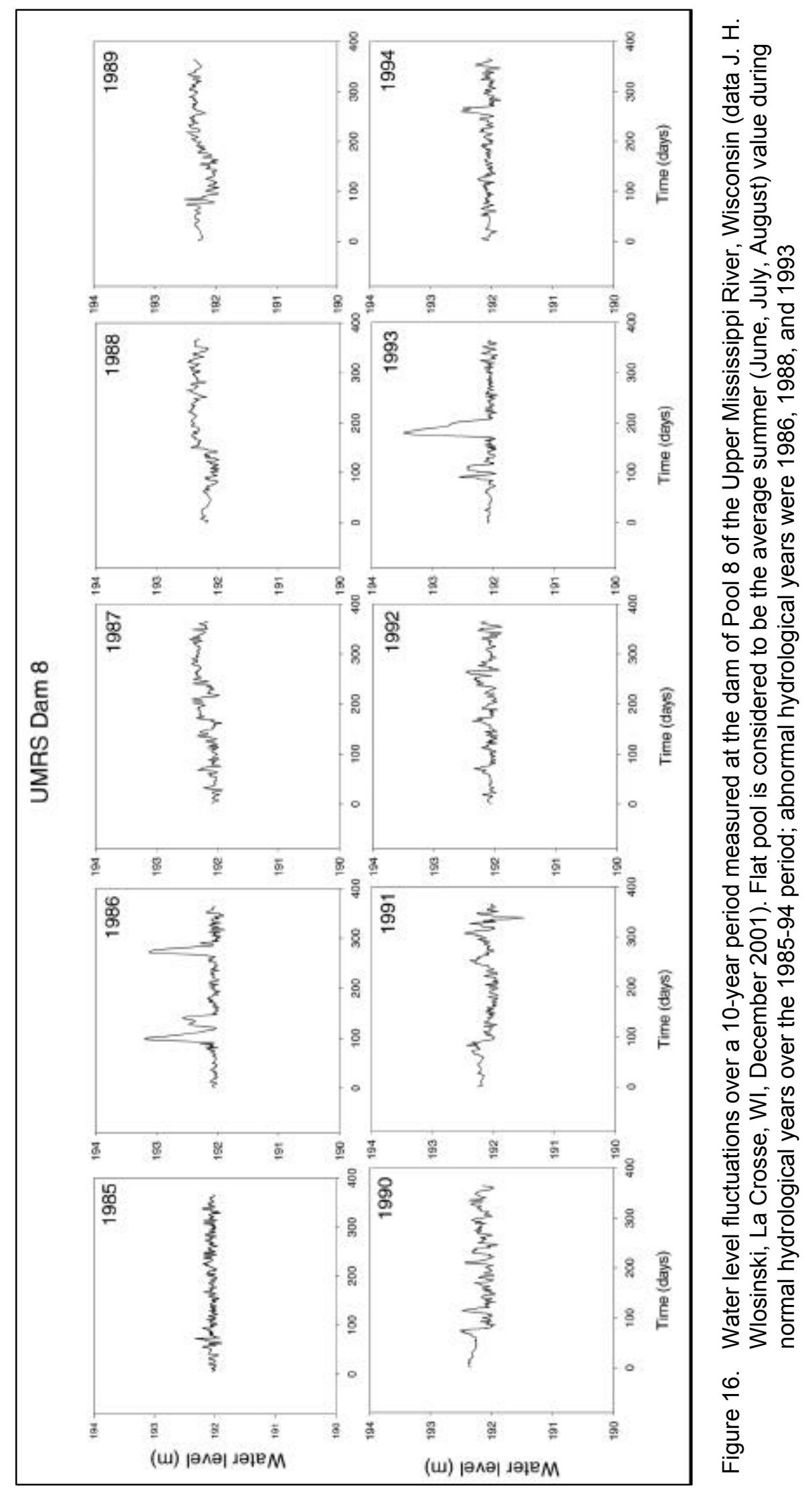




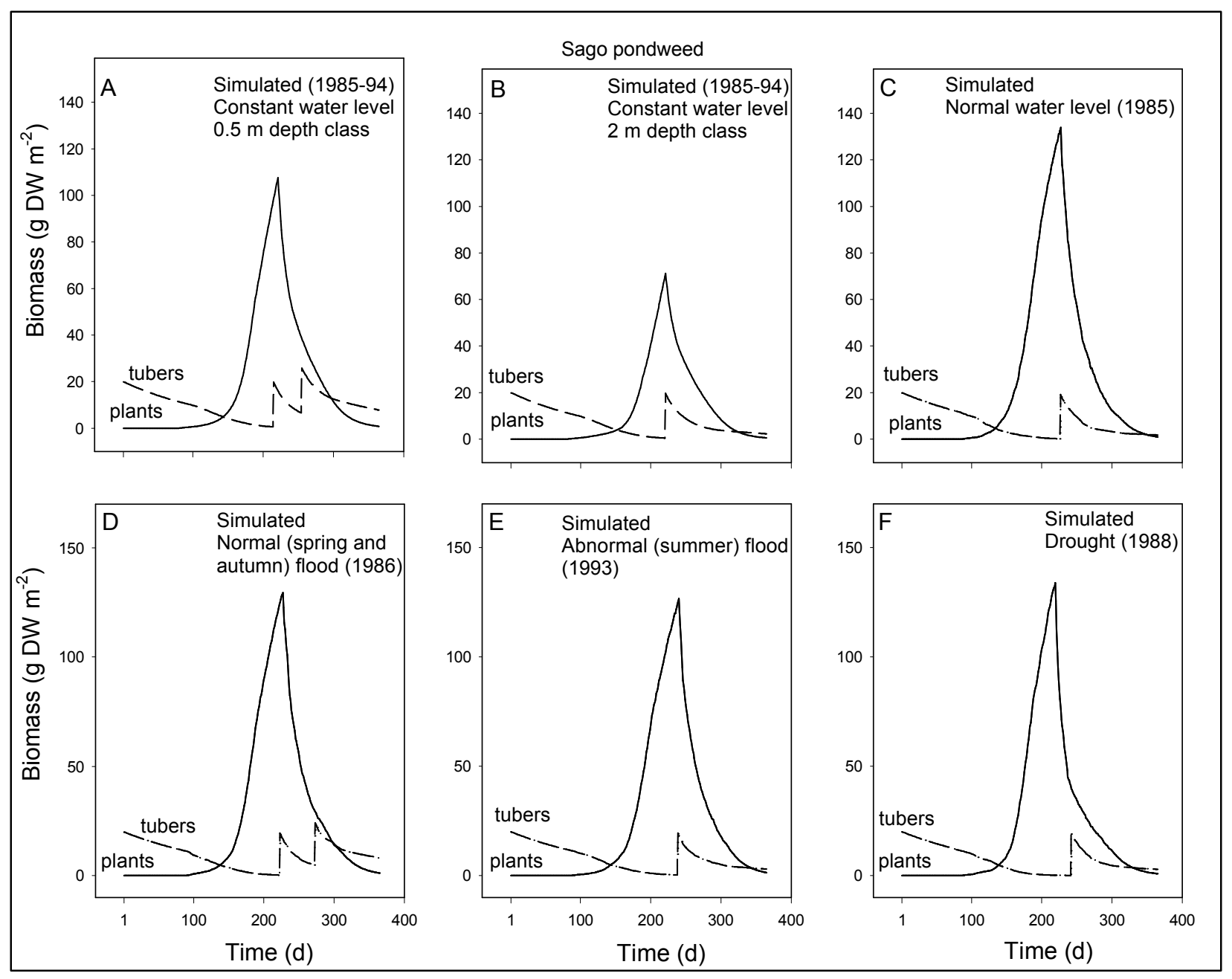

Figure 17. Comparison of simulated data on biomass of plants and tubers of sago pondweed in the Upper Mississippi River. Historical data on macrophyte occurrence in Pool 8 (longitude $91^{\circ} 30^{\prime} \mathrm{W}$, latitude $43^{\circ} 30^{\prime} \mathrm{N}$ ) during the period $1993-98^{1}$ used as a reference. Simulations: Nominal initial biomass data; light extinction coefficients derived from 10-year average background total suspended solids values measured in the nearby Pool 4 in the 1980's (Bartell et al. 2000); climatological data, Minneapolis/St. Paul, Minnesota (longitude $93^{\circ} \mathrm{W}$, latitude $45^{\circ} \mathrm{N}$ ). (A) and (B) Constant water levels; climate, average 1985-94; (C) Water level, daily values $0.5-\mathrm{m}$ depth class; climate 1985 ; (D) Water level, daily values $0.5-\mathrm{m}$ depth class; climate, 1986; (E) Water level, daily values 0.5-m depth class; climate 1993; (F) Water level, daily values $0.5-\mathrm{m}$ depth class; climate, 1988

\footnotetext{
${ }^{1}$ Personal Communication, December 2000, Y. Yin, U.S. Geological Survey, Upper Midwest Environmental Sciences Center, La Crosse, WI.
} 
stimulation of algal blooms. The seasonal changes in the light extinction coefficient were kept the same in all simulations.

This example illustrates how relatively low- and high-frequency fluctuations in water levels might affect submersed plant populations, without even taking plant adaptation into consideration. Ability of plants to adapt to changes in water level may be an important characteristic for their persistence in rivers, reservoirs, and estuaries. Although this ability is a rather intensively discussed research topic, pertinent ecological data are currently largely lacking. The field observations indicating large portions of sago pondweed populations disappeared after the 1988 drought (Green 1960) and 1993 unusual flood (Spink and Rogers 1996) may be explained by desiccation of tubers in shallow areas that fell dry, and dislodgement of tubers in areas exposed to unusual current velocities, both phenomena not described in the current POTAM model.

\section{Simulated Behavior of a Sago Pondweed Community Subject to Biomass Removal; Effects of Cutting and Grazing}

Effects of such man-made control activities as cutting at different times and at various water depths can be calculated also using POTAM. These control measures may be needed to free irrigation canals, such as those in agricultural areas in California, from obstructing aquatic weeds. Thus, in the latter case the model can be used as a tool by aquatic plant and lake management agencies.

\begin{tabular}{|c|c|c|c|c|c|}
\hline \multicolumn{6}{|c|}{$\begin{array}{l}\text { Table } 3 \\
\text { Effects of Cutting Date and Depth on Maximum Shoot Biomass } \\
\text { and End-of-Year Tuber Number }\end{array}$} \\
\hline Harvest Time & $\begin{array}{l}\text { Harvest } \\
\text { Depth } \\
\mathrm{m} \\
\end{array}$ & $\begin{array}{l}\text { Live Shoot } \\
\text { Biomass } \\
14 \text { July } \\
\text { g DW m }{ }^{-2}\end{array}$ & $\begin{array}{l}\text { Preharvest } \\
\text { Shoot } \\
\text { Biomass } \\
\text { g DW m }{ }^{-2}\end{array}$ & $\begin{array}{l}\text { Postharvest } \\
\text { Shoot Biomass } \\
\mathrm{g} \mathrm{DW} \mathrm{m}^{-2}\end{array}$ & $\begin{array}{l}\text { End-of-year } \\
\text { Tuber } \\
\text { Number } \\
\mathrm{N} \mathrm{m}^{-2}\end{array}$ \\
\hline \multicolumn{6}{|c|}{ Initial plant biomass 0} \\
\hline None & & 144.4 & & & 189 \\
\hline 1 April & 0.8 & 109.8 & 0.6 & 0.2 & 119 \\
\hline 1 June & 0.8 & 14.1 & 15.0 & 1.5 & 2 \\
\hline 1 July & 0.8 & 9.2 & 72.0 & 7.1 & 0 \\
\hline - & 0.1 & 133.4 & 72.0 & 68.7 & 234 \\
\hline 1 August & 0.8 & 144.4 & 96.3 & 9.0 & 0 \\
\hline 1 September & 0.8 & 144.4 & 57.4 & 5.5 & 0 \\
\hline
\end{tabular}

From Table 3 it can be concluded that sago pondweed vegetation at a 1-m anchorage depth starting from tubers alone does not produce such a high "nuisance" plant biomass in a relatively warm, temperate climate that it would hamper other uses of the water body by humans or wildlife, since peak plant biomass would not exceed $145 \mathrm{~g} \mathrm{DW} \mathrm{m}^{-2}$. A cutting regime aimed at reducing 
summer plant biomass concomitant with preventing tubers to be present at the end of the year would be most successful when implemented in the period between 1 June and 1 July with a cutting depth of $0.8 \mathrm{~m}$ (Table 3 ). Cutting to a lesser depth of $0.1 \mathrm{~m}$ in the same period would increase the end-of-year tuber number significantly by decreasing the self-shading effect of the plant canopy and, thus, allowing more light to reach the remaining plant portion. Since in a temperate climate usually no wintering plants are present, no simulations starting from biomass other than tubers were done. The same cutting regime applied to vegetation at a $0.5-\mathrm{m}$ anchorage depth indicated that in this case expected peak biomass would be about 50 percent higher. A small drawback of the model in simulating cutting effects is that the model allows the simulated plant material that remains after harvesting to be distributed directly (i.e., during the next time-step) over the water column again, resulting in a slightly higher peak biomass, while in reality the vegetation will need more time to recover from cutting.

Sago pondweed fruits, seeds, and tubers form an important food source largely for waterfowl, but also for mammals such as muskrat, beaver, and moose, and for fish (Fassett 1957; Dirksen 1982; Van Wijk 1988; Korschgen 1989; Kantrud 1990). Waterfowl species commonly grazing sago pondweed in the United States are diving ducks (Ayhtyinae), dabbling ducks, and geese (Anserinae). Waterfowl species grazing this plant in European waters are mostly coot (Fulica atra L.), less frequently mallard (Anas platyrhynchos L.), and swans. Studies carried out to quantify the effects of waterfowl grazing on sago pondweed populations list mostly short-term effects varying from reductions in mass ranging from 40 to 83 percent for plants and from 43 to 66 percent for turions and tubers (Anderson and Low 1976; Van Wijk 1988). Longer-term, > 1 year, effects are believed to be small to negligible (Sterling 1970; Anderson and Low 1976; Kantrud 1986). The reported effects concur with the model results described in the section "Effects of differences in tuber bank density and anchorage depth," where a population starting from a lower tuber bank density than normal would completely recover within a year due to decreased self-shading. However, simulations starting from small tubers under relatively warm climatological conditions, such as occurring in California $\left(<30 \mathrm{~m}^{-2}\right)$, indicated that populations starting from a lower than nominal tuber bank density would become extinct within a year. The latter phenomenon may be explained by the temperatureincreased respiration of the sprouts emerging from the tubers, causing carbohydrate depletion before the plantlets attain a self-supporting carbon gain level.

The current Version 1.0 of POTAM can be used as a tool to estimate the viable forage habitat for waterfowl by calculating the timing and tuber size and density for sago pondweed populations at various sites with and without fluctuating water level, and at various anchorage depths. When made spatially explicit by interfacing with a Geographic Information System (GIS), POTAM can be used as the main tool in calculating viable habitats for these birds and other animals. 


\section{Sensitivity Analysis}

A sensitivity analysis of a simulation model is required to assess the parameters likely to strongly affect model behavior. The current analysis was based on the effect of a change in a parameter when all other parameters are kept the same. As reference level, the nominal parameter values were chosen as presented in Table 2, under conditions at the Western Canal, The Netherlands, at $1.3-\mathrm{m}$ water depth. In a 1-year simulation starting with a tuber size of $0.083 \mathrm{~g} \mathrm{DW}$ and a tuber bank density of $240 \mathrm{~m}^{-2}$, the value of the parameter under study was changed. The results were compared with those of a nominal run. Each parameter was once increased by 20 percent and once decreased by 20 percent. The relative sensitivity (RS) of a parameter was then defined as the relative change in the variable on which the effect was tested divided by the relative change in the parameter (Ng and Loomis 1984). The effects of ten parameters on two variables, representing plant biomass aspects, were tested. A model variable is considered sensitive to a change in the value of a parameter at $\mathrm{RS}>0.5$ and $<-0.5$. The current sensitivity analysis was performed over a 1 -year period.

$$
R S=\frac{\left(\text { yield }_{i}-\text { yield }_{r}\right) / \text { yield }_{r}}{\left(\text { param }_{i}-\text { param }_{r}\right) / \text { param }_{r}}
$$

where

$$
\begin{aligned}
\text { yield }_{i}= & \text { value at parameter value } i \\
\text { yield }_{r}= & \text { value at reference parameter value; } \\
& \text { param }_{i} \text { and } \text { param }_{r} \text { as above }
\end{aligned}
$$

Maximum plant biomass proved most sensitive to changes in potential $\mathrm{CO}_{2}$ assimilation at light saturation for shoots, but not to changes in light use efficiency. It was also strongly affected by changes in pre-anthesis development rate. Maximum plant biomass proved to be insensitive to changes in the other parameters tested.

End-of-year tuber number was sensitive to seven out of the nine parameters tested (Table 4). Sensitivity was greatest to changes in pre-anthesis development rate, followed by changes in relative tuber growth rate, potential assimilation rate, light use efficiency, post-anthesis development rate, plant density, and relative death rate of the plants. End-of-year tuber number was insensitive to changes in individual tuber weight and relative conversion rate of tubers into plant material. 
This illustrates the utmost importance of the tubers for local survival and biomass production of sago pondweed.

\begin{tabular}{|c|c|c|c|}
\hline \multicolumn{4}{|c|}{$\begin{array}{l}\text { Table } 4 \\
\text { Relative Sensitivity of Two Model Variables to Deviations in } \\
\text { Parameter Values from Their Nominal Values as Presented in } \\
\text { Table } 2\end{array}$} \\
\hline \multirow[b]{2}{*}{ Parameter Name } & \multirow[b]{2}{*}{$\begin{array}{l}\text { Parameter } \\
\text { Value }\end{array}$} & \multicolumn{2}{|c|}{ Relative Sensitivity } \\
\hline & & $\begin{array}{l}\text { Maximum Live } \\
\text { Plant Biomass }\end{array}$ & $\begin{array}{l}\text { End-of-Year } \\
\text { Tuber Number }\end{array}$ \\
\hline \multirow{3}{*}{$\begin{array}{l}\text { Potential } \mathrm{CO}_{2} \text { assimilation rate at } \\
\text { light saturation for shoot tips }\end{array}$} & 0.019 & & \\
\hline & 0.0228 & 1.720 & -1.577 \\
\hline & 0.0152 & 1.941 & 5 \\
\hline \multirow[t]{3}{*}{ Light use efficiency } & 0.000011 & & \\
\hline & 0.000013 & 0.245 & -0.832 \\
\hline & 0.000008 & 0.324 & -3.095 \\
\hline \multirow{3}{*}{$\begin{array}{l}\text { Relative death rate for leaves, } \\
\text { stems and roots }\end{array}$} & 0.047 & & \\
\hline & 0.0564 & 0 & 0 \\
\hline & 0.0376 & 0 & -2.931 \\
\hline \multirow[t]{3}{*}{ Individual tuber weight } & 0.083 & & \\
\hline & 0.0996 & 0.246 & 0 \\
\hline & 0.0664 & 0.341 & 0.192 \\
\hline \multirow{3}{*}{$\begin{array}{l}\text { Relative conversion rate of tubers } \\
\text { into plant material }\end{array}$} & 0.0576 & & \\
\hline & 0.069 & 0.092 & 0 \\
\hline & 0.046 & 0.136 & 0 \\
\hline \multirow[t]{3}{*}{ Relative tuber growth rate } & 0.19 & & \\
\hline & 0.228 & -0.103 & -2.153 \\
\hline & 0.152 & -0.102 & 5 \\
\hline \multirow[t]{3}{*}{ Plant density } & 30 & & \\
\hline & 36 & 0.276 & 1.204 \\
\hline & 24 & 0.346 & 1.140 \\
\hline \multirow[t]{3}{*}{ Pre-anthesis development rate } & 0.015 & & \\
\hline & 0.018 & -1.360 & -3.363 \\
\hline & 0.012 & -0.913 & 4.914 \\
\hline \multirow[t]{3}{*}{ Post-anthesis development rate } & 0.040 & & \\
\hline & 0.048 & -0.392 & -0.426 \\
\hline & 0.032 & -0.451 & -3.123 \\
\hline
\end{tabular}

Earlier or later flowering biotypes are suited to different environments. The effect of changes in flowering date can be tested with the model by varying the pre-anthesis development rate of the vegetation. Faster rates represent earlier biotypes, and slower rates later biotypes. This sensitivity analysis shows that a faster pre-anthesis development rate than the nominal one leads to a lower peak plant biomass and end-of-year tuber number, but a slower pre-anthesis development rate leads to a lower peak plant biomass and higher end-of-year tuber number. The decreased peak biomass and increased tuber number in the latter case may be due to the relatively longer period in summer in which tubers can be initiated at the cost of plant biomass formation. Faster pre-anthesis development 
leads to a shorter growing season and less vegetative dry matter, incomplete light interception, and lower carbohydrate availability for organ formation. At the same time, however, the rate of organ formation increases but the period in which each organ is formed shortens. Changes in post-anthesis development rates did not affect peak plant biomass to a large extent, but a slower rate did decrease the endof-year tuber number. The latter decrease may be due to the relatively shorter period in which tubers can be initiated determined by the development stage of the plants concomitant with the occurrence of suitable environmental conditions for tuber initiation.

As far as is known, no publications exist on what the temperature requirements of aquatic plants are to traverse development from anthesis to senesced state. However, differences in post-anthesis development rates for several wheat and rice cultivars are known to be small and have little effect on yield (Van Keulen 1976).

Intuitive prediction of aquatic plant biotype behavior under variable climatic conditions is hazardous. The current model shows promise in being able to reproduce some of the complex vegetation responses and may be useful in evaluating long-term implications of differences in development rate. 


\section{Environmental Factor Analysis}

The impacts of various changes in environmental factors were assessed using the relative sensitivity of the affected variables as "measure." For this purpose, parameter changes were based on value ranges taken from literature, which sometimes differed more than 20 percent from the nominal parameter value given in Table 2.

\section{Climate}

Climate greatly affects plant species distribution, phenological cycle, and biomass production. POTAM can be used to calculate climate change effects on the chronological timing of the phenological events and on biomass production. It cannot be used to assess climate change effects on (a) plant species distribution, and (b) the phenological cycle itself since the phenological cycle has been used for calibration (see Chapter 3). Running the model under more southern climatological conditions, i.e., changing the latitude from 52 to $38^{\circ} \mathrm{N}$, demonstrated that both maximum plant biomass and end-of-year tuber number are sensitive to this climate change (Table 5).

\section{Light Reflection Coefficient by Water Surface}

The irradiance reflected by the water surface usually averages about 6 percent over a day. The values of this parameter tested were 0 and 1 . Reflection may theoretically have the value 0 when no reflection occurs at a 90-deg incoming angle of the radiation on a completely calm water surface (wind and wave action are minimal). The highest value of 1 may occur at a close to 180-deg incoming angle of the radiation and at very rough water surfaces.

Increasing the light reflection coefficient to 1 brought plant biomass back to zero within the year. That nevertheless low RS values were found (Table 5) is an artifact of the calculation method employed. Decreasing the light reflection coefficient barely affected maximum biomass and end-of-year tubers, probably because the majority of the plant material is located at the water surface (Table 5). 


\begin{tabular}{|c|c|c|c|}
\hline \multicolumn{4}{|c|}{$\begin{array}{l}\text { Table } 5 \\
\text { Environmental Factor Analysis, Expressed as Relative Sensitivity } \\
\text { of Two Model Variables to Deviations in Parameter Values from } \\
\text { Their Nominal Values as Presented in Table } 2\end{array}$} \\
\hline \multirow[b]{2}{*}{ Parameter Name } & \multirow[b]{2}{*}{ Parameter Value } & \multicolumn{2}{|c|}{ Relative Sensitivity } \\
\hline & & $\begin{array}{l}\text { Maximum Live Plant } \\
\text { Biomass }\end{array}$ & $\begin{array}{l}\text { End-of-Year Tuber } \\
\text { Number }\end{array}$ \\
\hline \multicolumn{4}{|c|}{ Climate } \\
\hline Zandvoort, NL (1987) & Latitude $52^{\circ} \mathrm{N}$ & - & - \\
\hline Davis, CA (1990) & Latitude $38^{\circ} \mathrm{N}$ & -1.540 & 1.425 \\
\hline \multirow{3}{*}{$\begin{array}{l}\text { Light reflection coefficient } \\
\text { by water surface }\end{array}$} & 0.06 & 0 & - \\
\hline & $\begin{array}{l}1.00(+1567 \\
\text { percent })\end{array}$ & -0.063 & -0.063 \\
\hline & $\begin{array}{l}0.00^{*}(-100 \\
\text { percent })\end{array}$ & -0.016 & 0.085 \\
\hline \multirow{3}{*}{$\begin{array}{l}\text { Light extinction coefficient } \\
\text { water column }\end{array}$} & 1.07 & & \\
\hline & $\begin{array}{l}1.284(+20 \\
\text { percent })\end{array}$ & -0.122 & 0.181 \\
\hline & $\begin{array}{l}0.856(-20 \\
\text { percent })\end{array}$ & -0.084 & 0.426 \\
\hline \multirow[t]{3}{*}{ Water depth } & 1.3 & & \\
\hline & 1.56 (+20 percent) & -0.019 & 0 \\
\hline & 1.04 (-20 percent) & 0.034 & 0 \\
\hline
\end{tabular}

\section{Light Extinction Coefficient of Water Column}

A light extinction coefficient of on average $1.07 \mathrm{~m}^{-1}$ is used for nominal runs of the model (Western Canal, The Netherlands).

Changing the light extinction coefficient of the water column demonstrated small effects on maximum plant and larger effects on the end-of-year tuber numbers. A nominal value of $2 \mathrm{~m}^{-1}$ has been found typical for eutrophic fen lakes where submersed vegetation can just persist (Best et al. 1985).

\section{Water Depth}

POTAM has been calibrated for a water depth of $1.3 \mathrm{~m}$, the anchorage depth of an extensively studied sago pondweed community in the Western Canal, The Netherlands. The model has the capability to respond to fluctuations in water level between years and within year, by (re)distributing plant biomass over the desired water depth (number of water layers; see Chapter 3). This technique for biomass distribution over the vertical axis of the community works well and gives realistic outcomes over a depth range of 0.1 to $6 \mathrm{~m}$. 
Running POTAM at an increased or decreased water depth showed negligible effects on maximum plant biomass and end-of-year tuber number, probably because the majority of the plant material is located at the water surface (Table 5). Larger effects are expected in plants with most of their biomass located near the sediment, such as American wildcelery.

The current sensitivity and environmental analyses give indications of the sensitivity of maximum plant biomass and end-of-year tuber number for variations in plant parameters and in environmental factors over a 1-year period. It is to be expected, however, that the small changes that occurred over this relatively short period will increase with time and that extrapolations in time will yield information on the likelihood for plant populations to ultimately persist or become extinct. Particularly, increased water turbidity, caused by increased phytoplankton or periphyton growth stimulated by eutrophication; increased erosion/ resuspension; and seasonal herbivory have been mentioned as decisive for the persistence of submersed plant populations. 


\section{Application Possibilities}

POTAM can be used to assess behavior of a sago pondweed community under various site-specific and climatological conditions as demonstrated in Chapters 4, 5, and 6, and the simulation model can be run with user-specified input values for plant biomass, tuber size/tuber number concurrently initiated, and tuber bank density.

Effects of such man-made activities as mechanical harvesting at different times and at various water depths, and water level and water quality management can also be calculated using the model. Thus, in the latter case it can be used as a tool for aquatic plant and water management agencies (see for instance Bartell et al. 2000).

The current version of POTAM has been developed as a stand-alone simulation model. It can be relatively easily modified to communicate with ecosystem models because it is written in FORTRAN77 and its structure is simple. A similar growth model, developed for American wildcelery, has been used to calculate the potential production of plant biomass and tubers in Peoria Lake, IL, with modeled data on hydrodynamics as inputs, and plant parameter outputs spatially visualized through interfacing with a Geographical Information System (Black et al. in preparation). To facilitate use of the current model, a user's manual has been prepared (Best and Boyd, in preparation). 


\section{Discussion}

The current model gives a reasonable description of the dynamics in plant biomass and tuber numbers of an established sago pondweed population under a variety of field conditions. As can be expected, the model is very sensitive to environmental changes affecting the light climate and, consequently, the carbon flow through the plant. The model is also sensitive to temperature, because the development phase of the plants is tied to degree-day (temperature) sum.

Light attenuation by periphyton may have large effects on submersed macrophytes with biomass usually remaining below the water surface (Vallisneria Americana) (Titus and Adams 1979) and those with most of their biomass concentrated just above the hydrosoil (Ceratophyllum demersum) (Best and Dassen 1987; Best and Jacobs 1990). Light extinction by periphyton has not yet been included in POTAM because no field data on periphyton biomass concomitant with photosynthetic activity were available. The recently (2002) collected data on periphyton mass and potential effects on the light climate within the macrophyte bed will be included in a later version.

Senescence, resulting in decreasing photosynthetic activity in aging plant parts, has been included in the model formulation, but because of lack of data this feature has not been activated. However, effects of senescence over the vertical plant axis proved to be negligible in other submersed plant species (Eurasian watermilfoil) (Best and Boyd 1999). 


\section{References}

Aleem, A. A., and Samaan, A. A. (1969). "Productivity of Lake Mariut, Egypt. Part II. Primary production,” Internationale Revue der Hydrobiologie 54, 491-527.

Amthor, J. S. (1984). "The role of maintenance respiration in plant growth," Plant, Cell, and Environment 7, 561-569.

Anderson, M. G., and Low, J. B. (1976). "Use of sago pondweed by waterfowl on Delta Marsh, Manitoba," Journal of Wildlife Management 40, 233-242.

Bartell, S. M., Campbell, K. R., Best, E. P. H., and Boyd, W. A. (2000).

"Ecological risk assessment of the effects of the incremental increase of commercial navigation traffic $(25,50,75$, and 100 percent increase of 1992 baseline traffic) on submerged aquatic plants in the main channel and main channel borders," Upper Mississippi River - Illinois Waterway System Navigation Study, ENV Report 17, prepared by the Cadmus Group, Oak Ridge, TN, and the U.S. Army Engineer Research and Development Center, Vicksburg, MS, for the U.S. Army Engineer Districts, Rock Island, St. Louis, St. Paul.

Basiouny, F. M., Haller, W. T., and Garrard, L. A. (1978). "Survival of Hydrilla (Hydrilla verticillata) plants and propagules after removal from the aquatic habitat," Weed Science 26, 502-504.

Bellrose, F. C., Havera, S. P., Paveglio, F. L., and Steffeck, D. W. (1983). "Fate of the lakes in the Illinois River valley," Illinois Natural History Survey Biology Note 119.

Bergmeyer, H. U. (1970). "Methoden der Enzymatische Analyse.” 2. Auflag. Verlag Chemie, Weinheim.

Best, E. P. H. (1981). “A preliminary model for growth of Ceratophyllum demersum L.," Verhaendlungen des Internationales Vereinigung fuer Limnologie 21, 1484-1491. . (1982). "Hormonal interactions in Ceratophyllum demersum," Aquatic Botany 13, 87-95. 
Best, E. P. H., and Boyd, W. A. (1996). "A simulation model for growth of the submersed aquatic macrophyte hydrilla (Hydrilla verticillata (L.F.) Royle." Technical Report A-96-8, U.S. Army Engineer Waterways Experiment Station, Vicksburg, MS.

. (1999). "A simulation model for growth of the submersed aquatic macrophyte Eurasian watermilfoil (Myriophyllum spicatum L.)," Technical Report E-99-3, U.S. Army Engineer Research and Development Center, Vicksburg, MS.

. (2001). "A simulation model for growth of the submersed aquatic macrophyte american wildcelery (Vallisneria americana Michx.)," Technical Report ERDC/EL TR-01-5, U.S. Army Engineer Research and Development Center, Vicksburg, MS.

"POTAM (Version 1.0): A simulation model for growth of sago pondweed-User's guide" (in preparation) U.S. Army Engineer Research and Development Center, Vicksburg, MS.

Best, E. P. H., and Dassen, J. H. A. (1987). "Biomass, stand area, primary production characteristics and oxygen regime of the Ceratophyllum demersum L. population in Lake Vechten, The Netherlands," Archiv fuer Hydrobiologie/Supplement 76, 347-367.

Best, E. P. H., De Vries, D., and Reins, A. (1985). "The macrophytes in the Loosdrecht Lakes: A story of their decline in the course of eutrophication," Verhaendlungen des Internationalen Vereinigungs Theoretische und Angewandte Limnologie 22, 868-875.

Best, E. P. H., and Jacobs, F. H. H. (1990). "Potential and actual production of submerged aquatic angiosperms common in temperate regions." Proceedings, 8th Symposium on Aquatic Weeds, 39-47.

Best, E. P. H., and Visser, H. W. C. (1987). "Seasonal growth of the submerged macrophyte Ceratophyllum demersum L. in mesotrophic Lake Vechten in relation to insolation, temperature and reserve carbohydrates," Hydrobiologia $148,231-243$.

Bick, H., and Van Schaik, A. W. J. (1980). “ Ecological vision border lakes.” Advice of the Natural Science Committee of the Nature Conservation Council, 291 pp. (In Dutch).

Black, P., Best, E. P. H., Newcomb, E. A., Birkenstock, T., Boyt, B., Heath, R., and James, W. F. "A pilot study of Vallisneria americana changes related to hydraulic modifications to Peoria Lake" (in preparation), U.S. Army Engineer Research and Development Center, Hanover, NH.

Blanch, S. J., Ganf, G. G., Walker, K. F. (1998). "Growth and recruitment in Vallisneria americana as related to average irradiance in the water column," Aquatic Botany 61, 181-205. 
Collins, C. D., and Wlosinski, J. H. (1985). "A macrophyte submodel for aquatic ecosystems," Aquatic Botany 33, 191-206.

Crow, G. E., and Hellquist, C. B. (2000). Aquatic and wetland plants of North America. 2, 36.

Dandy, J. E., and Taylor, G. (1946). "An account of Potamogeton x suecicus Richt. in Yorkshire and the Tweed," Proceedings Botanical Society of Edinburgh 34, 348-360.

Den Hartog, C. (1981). "Aquatic plant communities of poikilosaline waters," Hydrobiologia 81, 15-22.

Den Hartog, C. (1982). "Architecture of macrophyte-dominated aquatic communities." Studies on aquatic vascular plants. J.J. Symoens, S.S. Hoooper, and P. Compere, ed., Royal Botanical Society of Belgium, Brussels, 222-234.

De Vlaming, V., and Proctor, V. W. (1968). "Dispersal of aquatic organisms: Viability of seeds recovered from the droppings of captive killdeer and mallard ducks," American Journal of Botany 55, 20-26.

Dirksen, S. (1982). "The importance of pondweed for bewick swans in the Lauwersmeer," Limosa 55, 30-31 (In Dutch).

Doyle, R. D. (2000). "Effects of sediment resuspension and deposition on plant growth and reproduction," Upper Mississippi River - Illinois Waterway System Navigation Study, ENV Report 28, prepared by U.S. Army Engineer Research and Development Center, Vicksburg, MS, for U.S. Army Engineer Districts, Rock Island, St. Louis, St. Paul.

Fassett, N. C. (1957). "A manual of aquatic plants.” University of Wisconsin Press, Madison, WI.

Fernald, M. L. (1950). Gray's manual of botany. 8th ed., American Book Company, New York, 1632 pp.

Fischer, J. R., and Claflin, T. O. (1992). "Macrophyte community changes in navigation Pool 8, Upper Mississippi River, between 1975 and 1991." Proceedings Mississippi River Research Consortium, Inc., Vol. 24.

Giesen, W. B. J. T., Van Katwijk, M. M., and Den Hartog, C. (1990). "Eelgrass condition and turbidity in the Dutch Wadden Sea," Aquatic Botany 37, 71-85.

Gijzen, H. (1985). "Simulatie van drogestof-produktie en de Leaf Area Index van cassave." MS Thesis, Department of Tropical Crop Science, Wageningen Agricultural University, The Netherlands (In Dutch).

Gleason, H. A. (1968). The new Britton and Brown illustrated flora of the Northeastern United States and adjacent Canada. Hafner, New York, Vol 1, $482 \mathrm{pp}$. 
Godfrey, R. K., and Wooten, J. W. (1997). Aquatic and wetland plants of Southeastern United States, monocotyledons. The University of Georgia Press, Athens, $711 \mathrm{pp}$.

Golterman, H. L. (1975). Physiological limnology. An approach to the physiology of lake ecosystems. Elsevier Scientific Publishing Company, Amsterdam, $489 \mathrm{pp}$.

Goudriaan, J. (1986). "A simple and fast numerical method for the computation of daily totals of crop photosynthesis," Agricultural and Forest Meteorology 38, 251-255.

Goudriaan, J., Van Keulen, H., and Van Laar, H. H. (1992). "Crop growth model for potential production (SUCROS1)." Simulation of crop growth for potential and water-limited production situations (as applied to spring wheat). Post-graduate course "Simulation of plant growth and crop production," Pontignano, Siena, Italy, 3-12 November, 1992, 1-25.

Green, W. E. (1960). "Ecological changes on the Upper Mississippi River Wildlife and Fish Refuge since inception of the 9-foot channel." Proceedings $10^{\text {th }}$ Annual Meeting Upper Mississippi Resources Conservation Committee, 58-70.

Griffin, K. L. (1994). "Caloric estimates of construction cost and their use in ecological studies," Functional Ecology 8, 551-562.

Grime, J. P. (1979). "Plant strategies and vegetative processes." John Wiley \& Sons, Chichester. 222 pp.

Guppy, H. B. (1897). "On the postponement of the germination of seeds of aquatic plants," Proceedings of the Royal Physical Society of Edinburgh 13, 344-360.

Gupta, R. K. (1968). Flora Nainitalenses. Mawagag Traders Publishing, New Delhi.

Haag, R. W. (1983). "Emergence of seedlings of aquatic macrophytes from lake sediments," Canadian Journal of Botany 61, 148-156.

Hagstrom, J. O. (1916). "Critical researches on the Potamogetons," Kungl. Svenska Vet. Handl. 55 (5), 281 pp.

Hammer, U. T., and Heseltine, J. M. (1988). "Aquatic macrophytes in saline lakes of the Canadian prairies," Hydrobiologia 158, 101-116.

Harrison, J. W. (1949). "Potamogeton in the Scottish Western isles, with some remarks on the general natural history of the species," Transactions of the Botanical Society of Edinburgh 35, 1-25.

Hettiararchi, P. L., and Triest, L. (1986). "Isoenzyme polymorphism of Potamogeton pectinatus L." Proceedings of the 7th International Symposium on Aquatic Weeds. European Weed Research Society and Association of Applied Biologists, 163-168. 
Hewitt, B. R. (1958). "Spectrophotometric determination of total carbohydrate," Nature 182, 246-247.

Hodgson, R. H. (1966). "Growth and carbohydrate status of sago pondweed," Weeds 14, 263-268.

Hootsmans, M. J. M. (1991). "A growth analysis model for Potamogeton pectinatus L.." Macrophytes, a key to understanding changes caused by eutrophication in shallow freshwater ecosystems. M. J. M. Hootsmans and J. E. Vermaat, IHE Report Series 21, Delft, The Netherlands, 263-311.

Howard-Williams, C. (1978). "The growth and reproduction of aquatic macrophytes in a south temperate saline lake," Verhaendlungen Internationale Vereinigung der Limnologie 20, 1153-1158.

Howard-Williams, C. (1981). "Studies on the ability of a Potamogeton pectinatus community to remove dissolved nitrogen and phosphorus compounds from lake water," Journal of Applied Ecology 18, 619-637.

Hunt, R. (1982). Plant growth curves. Arnold, London.

Kadono, Y. (1982). "Distribution and habitat of Japanese Potamogeton," Botanical Magazine of Tokyo 95: 63-76.

Kalkman, L., and Van Wijk, R. J. (1984). "On the variation in chromosome number in Potamogeton pectinatus L.," Aquatic Botany 20, 343-349.

Kantrud, H. A. (1986). "Western Stump Lake, a major canvasback staging area in eastern North Dakota," Prairie Naturalist 18, 247-253.

Kantrud, H. A. (1990). "Sago pondweed (Potamogeton pectinatus L.): A literature review," Publication 176, U.S. Fish and Wildlife Service, Fish and Wildlife Resource, 89 pp.

Kartesz, J. T., and Kartesz, R. (1980). "A synonymized checklist of the vascular flora of the United States, Canada, and Greenland." Vol. II. The biota of North America. University of North Carolina Press, Chapel Hill, 498 pp.

Kautsky, L. (1987). "Life cycles of three populations of Potamogeton pectinatus at different degrees of wave exposure in the Asko area, Northern Baltic proper," Aquatic Botany 27, 177-186.

Klaine, S. J., and Ward, C. H. (1984). "Environmental and chemical control of vegetative dormant bud production in Hydrilla verticillata," Annals of Botany 53, 503-514.

Kooman, P. L. (1995). "Genotype-environment interaction in potato 2: Dry matter allocation and duration of the growth cycle." Yielding ability of potato crops as influenced by temperature and daylength, $\mathrm{Ph}$. D. diss., Agricultural University Wageningen, Chapter 5, 71-89. 
Korschgen, C. E. (1989). "Riverine and deepwater habitats for diving ducks." Habitat management for migrating and wintering waterfowl in North America. L. M. Smith, R. L. Pederson, and R. M. N. Kaminski, ed., Texas Tech University Press, Lubbock.

Korschgen, C. E., George, L. S., and Green, W. L. (1988). "Feeding ecology of canvasbacks staging on Pool 7 of the Upper Mississippi River." Waterfowl in winter. M.W. Weller, ed., University of Minnesota Press, Minneapolis, 237250 .

Lapirov, A. G., and Petukhova, L. V. (1985). "The rhythm of development of fennel-leaved pondweed in the Uglitch reservoir," Biol vnutr. vod, Inform. Bull. 66, 10-13 (In Russian).

Lohammar, G. (1938). "Wasserchemie und hohere Vegetation Schwedischer Seen," Symb. Bot. Upsal. 3, 1-252.

Lovvorn, J. R. (1989). "Distributional responses of canvasback ducks to weather and habitat change," Journal of Applied Ecology 26, 113-130.

Lovvorn, J. R., and Gillingham, M. P. (1996). "Food dispersion and foraging energetics: A mechanistic synthesis for field studies of avian benthivores," Ecology 77, 435-451.

Madsen, J. D., and Adams, M. S. (1988). "The seasonal biomass and productivity of the submerged macrophytes in a polluted Wisconsin stream," Freshwater Biology 20, 41-50.

Martin, A., Zim, H., and Nelson, A. (1951). American wildlife and plants $-A$ guide to wildlife food habits. Dover Publications, Inc., New York, 500 pp.

Mason, H. L. (1969). A flora of the marshes of California. University of California Press, Berkeley, 878 pp.

Ng, E., and Loomis, R.S. (1984). "Simulation of growth and yield of the potato crop," Simulation Monographs, Pudoc, Wageningen, 147 p.

Ozimek, T., Prejs, K., and Prejs, A. (1986). "Biomass and growth rate of Potamogeton pectinatus L. in lakes of different trophic state," Ekologia Polska 34, 125-131.

Pederson, R. L., and Van der Valk, A. G. (1984). "Vegetation change and seed banks in marshes: Ecological and management implications," Transactions of the North American Wildlife Natural Resources Conference 49, 271-280.

Penning de Vries, F. W. T. (1975). "The cost of maintenance processes in plant cells," Annals of Botany 39, 77-92.

Penning de Vries, F. W. T., and Van Laar, H. H. (1982a). "Simulation of growth processes and the model BACROS." Simulation of plant growth and crop production. Pudoc, Wageningen, 99-102. 
Penning de Vries, F. W. T., and Van Laar, H. H. (1982b). "Simulation of growth processes and the model BACROS." Simulation of plant growth and crop production. Pudoc, Wageningen, 114-131.

Penning de Vries, F. W. T., Jansen, D. M., Ten Berge, H. F. M., and Bakema, A. (1989a). "Morphological development and assimilate partitioning."

Simulation of ecophysiological processes of growth in several annual crops. Chapter 3, Pudoc, Wageningen, 49-56.

Penning de Vries, F. W. T., Jansen, D. M., Ten Berge, H. F. M., and Bakema, A. (1989b). "Morphological development and assimilate partitioning."

Simulation of ecophysiological processes of growth in several annual crops. Chapter 3, Pudoc, Wageningen, 73-115.

Philbrick, C. T., and Anderson, G. J. (1987). "Implications of pollen/ovule ratios and pollen size for the reproductive biology of Potamogeton and autogamy in aquatic angiosperms," Systematic Botany 12, 98-105.

Pilon, J. (1999). "Progress Report, 1998." Netherlands Institute of Ecology, Royal Dutch Academy of Sciences, Nieuwersluis, The Netherlands.

Pilon, J., and Santamaria, L. (2002). "Clonal variation in the thermal response of the submerged aquatic macrophyte Potamogeton pectinatus," Journal of Ecology 90, 141-152.

Pip, E. (1987). "The ecology of Potamogeton species in central North America," Hydrobiologia 153, 203-216.

Rabbinge, R., and De Wit, C. T. (1989). "Theory of modelling and systems management." Simulation and systems management in crop protection. R. Rabbinge, S. A. Ward and H. H. van Laar, ed., Chapter 1. Simulation Monographs 32, Pudoc, Wageningen, 1-12.

Ramirez, C., and San Martin, J. (1984). "Hydrophilous vegetation of a coastal lagoon in central Chile," International Journal of Ecological and Environmental Sciences 10, 93-110.

Ridley, H. N. (1930). The dispersal of plants throughout the world. L. Reeve and Company, Ltd., London, 744 pp.

Rogers, S. J. (1996). "Preliminary evaluation of submersed macrophyte changes in the Upper Mississippi River," Lake and Reservoir Management 10, 35-38.

Sahai, R., and Sinha, A. B. (1973). "Productivity of submerged macrophytes in polluted and non-polluted regions of the eutrophic Lake Ramgarh (U.P.)." Aquatic weeds in South East Asia. Proceedings of a Regional Seminar on Noxious Aquatic Vegetation, New Delhi, 12-17 December, 1973. C. K. Varshney and J. Rzoska, ed., 131-140.

Scheffer, M. (1991). "On the prediction of aquatic vegetation in shallow lakes," Memorie dell' Istituto Italiano di Idrobiologia 48, 207-217. 
Scheffer, M., Bakema, A. H., and Wortelboer, F. G. (1993). "MEGAPLANT: A simulation model of the dynamics of submerged plants," Aquatic Botany 45, 341-356.

Sher-Kaul, S., Oertli, B., Castella, E., and Lachavanne, J. B. (1995).

"Relationship between biomass and surface area of six submerged aquatic plant species," Aquatic Botany 51: 147-154.

Sinha, A. B. (1970). "Studies on the bioecology and production in Ramgarh Lake, Gorakhpur," Ph. D. diss., Gorakhpur University, India.

Spence, D. H. N., and Maberly, S. C. (1984). "Occurrence and ecological importance of $\mathrm{HCO}_{3}$ - use among aquatic higher plants." Inorganic carbon uptake by aquatic photosynthetic organisms. Proceedings of an International Workshop on Bicarbonate Use in Photosynthesis, University of California, Davis, August 18-22, 1984, W. J. Lucas and J. A. Berry, ed., 125-145.

Spencer, D. F. (1987). "Tuber size and planting depth influence growth of Potamogeton pectinatus L.," The American Midland Naturalist 118, 77-84.

Spencer, D. F., and Anderson, L. W. J. (1986). "Photoperiod responses in monoecious and dioecious Hydrilla verticillata," Weed Science 34, 551-557.

Spencer, D. F., and Anderson, L. W. J. (1987). "Influence of photoperiod on growth, pigment composition and vegetative propagule formation for Potamogeton nodosus Poir. and Potamogeton pectinatus L.," Aquatic Botany 28, 102-112.

Spencer, W., and Bowes, G. (1990). "Ecophysiology of the world's most troublesome aquatic weeds." Aquatic Weeds, The ecology and management of nuisance aquatic vegetation. A. H. Pieterse and K. J. Murphy, ed., Oxford University Press, 39-74.

Spencer, D. F., Ksander, G. G., and Whitehand, L. C. (1994). "Estimating the abundance of subterranean propagules of submersed aquatic plants," Freshwater Biology 31, 191-200.

Spencer, D. F., Ryan, F. J., and Ksander, G. G. (1997). "Construction costs for some aquatic plants," Aquatic Botany 56, 203-214.

Spink, A., and Rogers, S. (1996). "The effects of a record flood on the aquatic vegetation of the Upper Mississippi River System: Some preliminary findings," Hydrobiologia 340, 51-57.

Spitters, C. J. T. (1986). "Separating the diffuse and direct component of global radiation and its implications for modeling canopy photosynthesis. II. Calculation of canopy photosynthesis," Agricultural and Forest Meteorology $38,231-242$.

Sterling, M. R. (1970). "Seasonal utilization of sago pondweed by waterfowl at Bear River Migratory Bird Refuge, Utah,” M.S. Thesis, Utah State University, Logan. $121 \mathrm{pp}$. 
Sutton, D. L., Littell, R. C., and Langeland, K. A. (1980). "Intraspecific competition of Hydrilla verticillata," Weed Science 28, 425-428.

Terras, J. A. (1900). "Notes on the germination of winter-buds of Hydrocharis morsus-ranae," Transactions, Proceedings of the Botanical Society of Edinburgh 21, 318-329.

Thornley, J. H. M., and Johnson, I. R. (1990a). "Temperature effects on plant and crop processes." Plant and crop modeling, A mathematical approach to plant and crop physiology. Clarendon Press, Oxford, 139-144.

Thornley, J. H. M., and Johnson, I. R. (1990b). "Plant growth functions." Plant and crop modeling, A mathematical approach to plant and crop physiology. Clarendon Press, Oxford, 74-89.

Titus, J., and Adams, M. A. (1979). "Coexistence and the comparative light relations of the submersed macrophytes Myriophyllum spicatum L. and Vallisneria americana Michx," Oecologia 40, 273-286.

Titus, J., Goldstein, R. A., Adams, M. A., Mankin, J. B., O’Neill, R. V., Weiler, P. R., Shugart, H. H., and Booth, R. S. (1975). "A production model for Myriophyllum spicatum L.," Ecology 56, 1129-1138.

Uhl, N. W. (1947). "Studies in the floral morphology and anatomy of certain members of the Helobiae," Ph.D Thesis, Cornell University, USA.

U.S. Department of Agriculture. (1982). "National list of scientific plant names. Vol.1. List of plant names," SCS-TP-159, U.S. Department of Agriculture, Soil Conservation Service.

Van, T. K., Haller, W. T., and Bowes, G. (1978). "Some aspects of the competitive biology of Hydrilla." Proceedings, $5^{\text {th }}$ EWRS International Symposium on Aquatic Weeds, Amsterdam (The Netherlands). 117-126.

Van der Bijl, L., Sand-Jensen, K., and Hjermind, A. L. (1989). "Photosynthesis and canopy structure of a submerged plant Potamogeton pectinatus, in a Danish lowland stream," Journal of Ecology 77, 947-962.

Van Dijk, G. M., and Achterberg, E. P. (1992). "Light climate in the water column of a shallow eutrophic lake (Lake Veluwe) in The Netherlands," Archiv fuer Hydrobiologie 125, 257-278.

Van Dijk, G. M., Breukelaar, A. W., and Gijlstra, R. (1992). "Impact of light climate history on seasonal dynamics of a field population of Potamogeton pectinatus L. during a three year period (1986-1988)," Aquatic Botany 43, 1741.

Van Keulen, H. (1976). "Evaluation of models," Critical evaluation of systems analysis in ecosystems research and management, G. W. Arnold and C. T. de Wit, ed., Simulation Monographs, Pudoc, Wageningen, 22-29.

Van Kraalingen, D. W. G. (1995). "The FSE System for Crop Simulation." ABDLO Report. Wageningen, The Netherlands. 53 pp. 
Van Vierssen, W., and Verhoeven, J. T. A. (1983). "Plant and animal communities in brackish supra-littoral pools ("dobben") in the northern part of The Netherlands," Hydrobiologia 98, 203-221.

Van Wijk, R. J. (1983). "Life-cycles and reproductive strategies of Potamogeton pectinatus L. in The Netherlands and the Camargue (France)," Proceedings of the International Symposium on Aquatic Macrophytes, Nijmegen, The Netherlands, 18-23 September, 1983. 317-321.

Van Wijk, R. J. (1986). "Life cycle characteristics of Potamogeton pectinatus L. in relation to control." Proceedings EWRS/AAA $7^{\text {th }}$ Symposium on Aquatic Weeds. 375-379.

Van Wijk, R. J. (1988).'Ecological studies on Potamogeton pectinatus L. I. General characteristics, biomass production and life cycles under field conditions," Aquatic Botany 31, 211-258.

Van Wijk, R. J. (1989).’Ecological studies on Potamogeton pectinatus L. III. Reproductive strategies and germination ecology," Aquatic Botany 33, 271299.

Van Wijk, R. J., Van Goor, E., and Verkley, J. A. C. (1988). "Ecological studies on Potamogeton pectinatus L. II. Autecological characteristics with emphasis on salt tolerance, intraspecific variation and isoenzyme patterns," Aquatic Botany 32, 239-260.

Vermaat, J. E., and Hootsmans, M. J. M. (1994a). "Intraspecific variation in Potamogeton pectinatus L.: A controlled laboratory experiment.” Lake Veluwe, a macrophyte-dominated system under eutrophication stress. W. Van Vierssen, M. Hootsmans, and J. Vermaat, ed., Kluwer Academic Publishers, Dordrecht, Boston, London, Chapter 4, 26-39.

Vermaat, J. E., and Hootsmans, M. J. M. (1994b). "Light-response curves of Potamogeton pectinatus L. in a temperature-light gradient." Lake Veluwe, a macrophyte-dominated system under eutrophication stress, W. Van Vierssen, M. Hootsmans, and J. Vermaat, ed., Kluwer Academic Publishers, Dordrecht, Boston, London, Chapter 6, 62-117.

Voss, E. (1972). Michigan Flora. Part I - Gymnosperms and monocots. Cranbrook Institute of Science, Bloomfield Hills, Michigan. 488 pp.

Weber, J. A., and Nooden, L. D. (1974). "Turion formation and germination in Myriophyllum verticillatum: Phenology and its interpretation," Michigan Botanist 13, 151-158.

Westlake, D. F. (1964). "Light extinction, standing crop and photosynthesis within weed beds," Verhaendlungen internationaler Vereinigung der Limnologie 15, 415-425.

Wetzel, R. L., and Neckles, H. A. (1996). “A model of Zostera marina L. photosynthesis and growth: Simulated effects of selected physical-chemical variables and biological interactions," Aquatic Botany 26, 307-323. 
Wiegleb, G. (1978). “Untersuchungen uber den Zusammenhang zwischen hydrochemischen Umweltfaktoren und Makrophytenvegetation in stehenden Gewassern," Archiv fuer Hydrobiologie 83, 443-484.

Williams, K., Percival, F., Merino, J., and Mooney, H. A. (1987). "Estimation of tissue construction cost from heat combustion and organic nitrogen content," Plant Cell and Environment 10, 725-734.

Winston, R. E., and Gorham, P. R. (1979). "Turions and dormancy states in Utricularia vulgaris," Canadian Journal of Botany 57, 2740-2749.

Wong, S. L., and Clark, B. (1976). "Field determination of the critical nutrient concentration for Cladophora in streams," Journal of the Fisheries Research Board of Canada 33, 85-92.

Yeo, R. R. (1965). “Life history of sago pondweed,” Weeds 13, 314-321. 


\section{Appendix A Model Listing}

*

* SUBROUTINE MODEL

* Authors: Elly Best \& Will Boyd

* Date : 18 August 1999

${ }^{*}$ Purpose: This subroutine is the translated FST file

* FORMAL PARAMETERS: (I=input, $\mathrm{O}=$ output, $\mathrm{C}=$ control, $\mathrm{IN}=$ init, $\mathrm{T}=$ time $)$

* name type meaning

${ }^{*}$ DELT

R4

* DOY

R4

Time step of integration

${ }^{*}$ FILEIN

$C^{*}$

${ }^{*}$ FINTIM

Day number within year of simulation (REAL)

* IDOY

R4

Name of file with input model data

* ITASK

Finish time of simulation (=day number)

* IUNITD

14

Day number within year of simulation (INTEGER)

14 Task that subroutine should perform

* IUNITO

Unit of input file with model data

* IUNITL

Unit of output file

* IYEAR

Unit number for log file messages

* LAT

Year of simulation (INTEGER)

* LONG

Latitude of site

${ }^{*}$ ELEV

Longitude of site

Elevation of site

* OUTPUT L4

${ }^{*}$ RAIN R4

${ }^{*} \mathrm{RDD} \quad \mathrm{R} 4$

Flag to indicate if output should be done

Daily amount of rainfall

Daily shortwave radiation

* STTIME R4

Start time of simulation (=day number)

* TERMNL L4 Flag to indicate if simulation is to stop

* TMMN R4

* TMMX R4

Daily minimum temperature

Daily maximum temperature

${ }^{*} \mathrm{VP}$

R4

Early morning vapour pressure

${ }^{*} \mathrm{WN}$

R4

Daily average windspeed

* WSTAT C6

Status code from weather system

* WTRTER L

* YEAR

L4

Flag whether weather can be used by model

Year of simulation (REAL)

* Fatal error checks: if one of the characters of WSTAT = '4', indicates missing weather

* Warnings : none

* Subprograms called: models as specified by the user

* File usage : IUNITD,IUNITD+1,IUNITO,IUNITO+1,IUNITL 


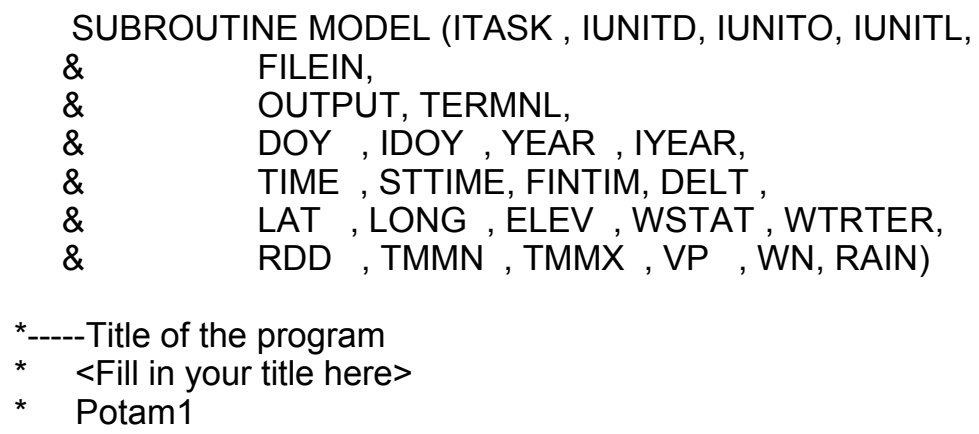


*-----AFGEN functions

* REAL AMDVST

* INTEGER IMAMDV, ILAMDV

* PARAMETER (IMAMDV = 40)

* DIMENSION AMDVST(IMAMDV)

REAL AMTMPT

INTEGER IMAMTM, ILAMTM

PARAMETER (IMAMTM = 40)

DIMENSION AMTMPT(IMAMTM)

REAL DPTT

INTEGER IMDPT, ILDPT

PARAMETER (IMDPT = 730)

DIMENSION DPTT (IMDPT)

REAL FLT

INTEGER IMFLT, ILFLT

PARAMETER (IMFLT $=40)$

DIMENSION FLT (IMFLT)

REAL FLVT

INTEGER IMFLVT, ILFLVT

PARAMETER (IMFLVT $=40)$

DIMENSION FLVT (IMFLVT)

REAL FRTT

INTEGER IMFRTT, ILFRTT

PARAMETER (IMFRTT $=40)$

DIMENSION FRTT (IMFRTT)

REAL FSTT

INTEGER IMFSTT, ILFSTT

PARAMETER (IMFSTT $=40$ )

DIMENSION FSTT (IMFSTT)

REAL LT, KT

INTEGER IMN1,ILT,IKT

PARAMETER $($ IMN1 $=730)$

DIMENSION LT(IMN1), KT(IMN1)

REAL NTMT, TGWMT

INTEGER IMMEAS, ILMEAS

PARAMETER (IMMEAS = 40)

DIMENSION NTMT(IMMEAS), TGWMT(IMMEAS)

REAL RDRT

INTEGER IMRDRT, ILRDRT

PARAMETER (IMRDRT $=40)$

DIMENSION RDRT (IMRDRT)

REAL RDST

INTEGER IMRDST, ILRDST

PARAMETER (IMRDST $=40)$

DIMENSION RDST (IMRDST)

REAL TEFFT

INTEGER IMTEFF, ILTEFF

PARAMETER (IMTEFF $=40$ )

DIMENSION TEFFT(IMTEFF)

REAL WTMPT

INTEGER IMWTMP, ILWTMP

PARAMETER $($ IMWTMP $=730)$

DIMENSION WTMPT (IMWTMP) 
*-----Used functions

REAL LINT , INSW

SAVE

DATA ITOLD /4/

*-----Code for the use of RDD, TMMN, TMMX, VP, WN, RAIN (in that order)

* A letter ' $U$ ' indicates that the variable is used in calculations DATA WUSED/'UUU---'/

*-----Check weather data availability

IF (ITASK.EQ.1.OR.ITASK.EQ.2.OR.ITASK.EQ.4) THEN

DO 10 IWVAR=1,6

*-----Is there an error in the IWVAR-th weather variable ?

IF (WUSED(IWVAR:IWVAR).EQ.'U' .AND.

\& WSTAT(IWVAR:IWVAR).EQ.'4') THEN

WTRTER $=$.TRUE.

TERMNL $=$.TRUE.

ITOLD = ITASK

END IF

RETURN

10 CONTINUE

END IF

IF (ITASK.EQ.1) THEN

* INITIALIZATION SECTION *

* =

*-----Send title to output file

*-----Open input file

CALL RDINIT (IUNITD, IUNITL, FILEIN)

*-----Read 1st value in MODEL.DAT file ... year number CALL RDSREA ('YRNUM ',YRNUM )

*-----Read initial states

CALL RDSREA ('INTUB ',INTUB )

CALL RDSREA ('IREMOB',IREMOB)

CALL RDSREA ('IWLVD ',IWLVD )

CALL RDSREA ('IWLVG ',IWLVG )

CALL RDSREA ('IWRTD ',IWRTD )

CALL RDSREA ('IWRTG ',IWRTG )

CALL RDSREA ('IWSTD ',IWSTD )

CALL RDSREA ('IWSTG ',IWSTG )

CALL RDSREA ('NUL 'NUL )

CALL RDSREA ('REMOB ',REMOB )

*-----Read model parameters

CALL RDSREA ('AMX ',AMX )

CALL RDSREA ('CRIFAC ',CRIFAC)

CALL RDSREA ('CVT ',CVT )

CALL RDSREA ('DAYEM ',DAYEM )

CALL RDSREA ('DELAY 'DELAY)

CALL RDSREA ('EE ',EE )

CALL RDSREA ('HAR ',HAR )

CALL RDSREA ('HARDAY',HARDAY)

CALL RDSREA ('HARDEP',HARDEP)

CALL RDSREA ('NDTUB ',NDTUB ) 
CALL RDSREA ('NINTUB ',NINTUB)

CALL RDSREA ('NPL ',NPL )

CALL RDSREA ('RC ',RC )

CALL RDSREA ('RCSHST',RCSHST)

CALL RDSREA ('RDTU ',RDTU )

CALL RDSREA ('REDAM ',REDAM )

CALL RDSREA ('ROC ',ROC )

CALL RDSREA ('RTR ',RTR )

CALL RDSREA ('SURPER',SURPER)

CALL RDSREA ('TBASE ',TBASE )

CALL RDSREA ('TL ',TL )

CALL RDSREA ('TWCTUB',TWCTUB)

*-----Read AFGEN functions

CALL RDAREA ('AMTMPT',AMTMPT,IMAMTM,ILAMTM)

CALL RDAREA ('DPTT ',DPTT ,IMDPT ,ILDPT )

CALL RDAREA ('FLT ',FLT ,IMFLT, ILFLT)

CALL RDAREA ('FLVT ',FLVT, ,IMFLVT,ILFLVT)

CALL RDAREA ('FSTT ',FSTT ,IMFSTT,ILFSTT)

CALL RDAREA ('FRTT ',FRTT ,IMFRTT,ILFRTT)

CALL RDAREA ('KT ',KT ,IMN1, IKT )

CALL RDAREA ('LT ',LT ,IMN1, ILT )

CALL RDAREA ('NTMT ',NTMT ,IMMEAS,ILMEAS)

CALL RDAREA ('RDRT ',RDRT ,IMRDRT,ILRDRT)

CALL RDAREA ('RDST ',RDST ,IMRDST,ILRDST)

CALL RDAREA ('TEFFT ',TEFFT, IMTEFF,ILTEFF)

CALL RDAREA ('TGWMT ',TGWMT ,IMMEAS, ILMEAS)

CALL RDAREA ('WTMPT','WTMPT ,IMWTMP,ILWTMP)

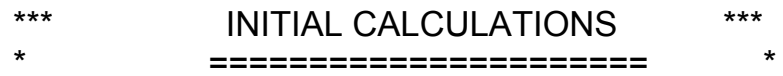

*-----Initially known variables to output

* Send title(s) to OUTCOM

*-----Initialize state variables

* Start at the beginning of the developmental cycle

DVS = NUL

TMPSUM = NUL

*-----Initialize counter KCOUNT \& SURFACE

KCOUNT $=0$

SURFAC $=0$

*-----DELAY and SSURPR variables are set from a REAL to an INTEGER

DDELAY = DELAY

SSURPR $=$ SURPER

*-----Initialize weights of plant organs

IF (YRNUM .EQ. 1.)THEN

TWLVD $=$ IWLVD

TWLVG $=$ IWLVG

TWSTD = IWSTD

TWSTG = IWSTG

TWRTD = IWRTD

TWRTG $=$ IWRTG

ENDIF 
*-----Initialize remobilization

TREMOB $=$ IREMOB

*-----Initialize tuber numbers and weight

NNTUB $=0.0$

IF (NDTUB .LT. 30.)NPL = NDTUB

NGTUB $=N P L$

IF(YRNUM.EQ.1.)NTUBD = RDTU * NDTUB * TEFF

NDTUB = NDTUB $-($ NTUBD-NTUBPD)

TWGTUB $=$ NPL * INTUB

TWNTUB $=0.0$

ELSE IF (ITASK.EQ.2) THEN

$* * *$

*

$$
\begin{aligned}
& \text { RATES OF CHANGE } \\
& \text { ニニニニニニニニニニニニニニニニ= }
\end{aligned}
$$

$* * *$

*-----Weights of plant organs

WLV = TWLVG + TWLVD

WST $=$ TWSTG + TWSTD

WRT = TWRTG + TWRTD

TGW $=$ TWLVG + TWSTG + TWRTG

*-----Total live weight never >1952 g DW / m2 ; cf. Howard Williams, 1978.

TGW = AMIN1 (TGW, 1952.)

**** RATE CALCULATIONS

* $\quad=================+$

*-----Julian day number

DAY = 1.+MOD (TIME-1.,365.)

*-----If water temperatures are available, temperature dependent processes are related to

* $\quad$ water temperature; otherwise they are related to air temperature with a lag period in

* $\quad \operatorname{day}(\mathrm{s})$ to be chosen by substituting number given for DELAY in MODEL.DAT

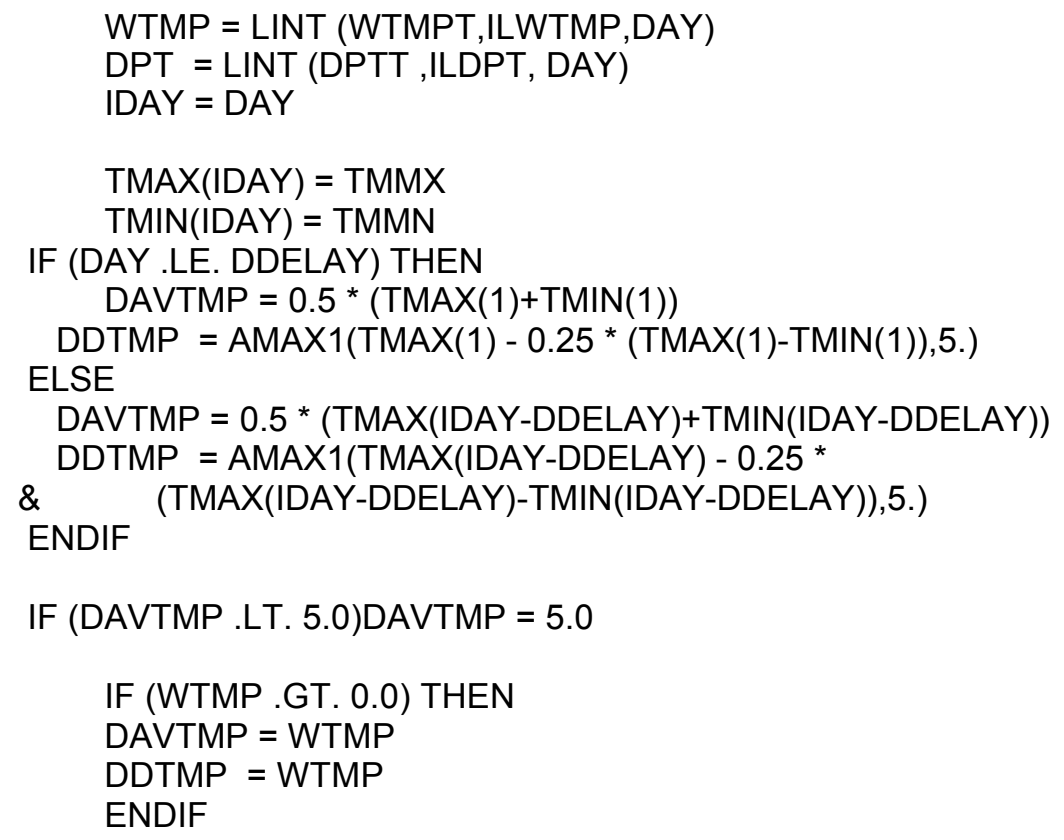


*-----Effective temperature influencing remobilization and translocation processes

TEFF $=$ LINT(TEFFT,ILTEFF,DDTMP)

*-----Relative tuber growth rate

$\mathrm{RTRL}=\mathrm{RTR} * \mathrm{TEFF}$

*-----Measured tuber numbers and measured total live plant dry weight

NTM = LINT (NTMT,ILMEAS,DAY)

TGWM = LINT (TGWMT,ILMEAS,DAY)

*-----SBRT ASTRO call to introduce day length into MAIN

CALL ASTRO

\$ (DAY,LAT,SC,DS0,SINLD,COSLD,DAYL,DSINB,DSINBE)

*------Tuber behavior.

* Sprouting of tubers leads to carbohydrate remobilization to form

* new plants, is related to DVS (calibrated to proper day length and temperature)

* $\quad$ provided tubers are present; sprouting can only take place before normal anthesis

* $\quad$ time (DVS=1). If plants lose their biomass after DVS $=1$, no new tubers

* $\quad$ sprout that same year. Tubers do sprout the next year, provided that tubers

* $\quad$ are present. Tubers are depleted up to 10 percent of their DW (per tuber).

TWTUB $=$ NDTUB $*$ INTUB

TWTUBD $=$ NTUBD * INTUB

IF (TWTUB .LE. 0.0)TWTUB $=0$.

IF (TWTUB .EQ. 0 .AND. DAY .EQ. 1)THEN

$\operatorname{WRITE}\left({ }^{*},{ }^{*}\right)^{\prime}$ There are no tubers !! -- Press <ENTER> '

$\operatorname{READ}\left({ }^{*},{ }^{*}\right)$

STOP

ENDIF

* Initialize variable(s) used in condition statement

* Tropical ... Latitude is less than or equal to $33 \mathrm{deg}$

IF (LAT .LE. 33.)THEN

$\mathrm{VAR} 1=.336$

$\operatorname{VAR} 2=1.6$

ELSE

* Temperate ... Latitude is greater than $33 \mathrm{deg}$

VAR $1=.210$

$\operatorname{VAR} 2=1.0$

ENDIF

IF (DVS .GE. VAR1 .AND. DVS .LT. VAR2)THEN

CPOTAMIN IF (DVS.GE. .210.AND. DVS .LT. 1.) THEN

CPOTAMIN IF (DVS .GE. .336 .AND. DVS .LT. 1.6) THEN

TWGTUB = INTGRL (TWGTUB, - REMOB,DELT)

TWGTUB = AMAX1 $(0.0$, TWGTUB $)$

IF (NDTUB .GT. 0.) THEN

REMOB $=$ TWGTUB ${ }^{*}$ ROC * TEFF

ENDIF

IF (TWGTUB .LE. $\left(0.01{ }^{*} \mathrm{NPL}\right.$ * INTUB $\left.)\right)$ NGTUB $=0.0$

ELSE

REMOB $=0.0$ 


\section{ENDIF}

*-----New tuber formation takes place at DVS $>1$ (temperate), daylength $<16 \mathrm{~h}$, and $5<$ water

* temperature $<28 \mathrm{oC}$, provided plant wght $>0.1 \mathrm{~g} \mathrm{DW} \mathrm{m-2}$; it continues until the

* $\quad$ weight of that tuber class reaches the critical tuber weight equal to (number of

* $\quad$ plants $\mathrm{m}-2) \mathrm{x}($ tuber number per plant)x tuber weight per tuber).

IF (REMOB .EQ. 0.0) THEN

* Initialize variable(s) used in condition statement

* Tropical ... Latitude is less than or equal to 33 deg

IF (LAT .LE. 33.)THEN

VAR1 $=1.6$

ELSE

* Temperate ... Latitude is greater than $33 \mathrm{deg}$

VAR1 $=1.0$

ENDIF

IF (DVS .GT. VAR1 .AND. DAYL .LT. 16.)THEN

CPOTAMIN IF (DVS.GT.1.0 .AND. DAYL.LT.16.)THEN

CPOTAMIN IF (DVS.GT.1.6 .AND. DAYL.LT.16.)THEN

IF (DDTMP .GT. 5.0 .AND. DDTMP .LT. 28.0)THEN

IF (TGW. GT. 0.1) THEN

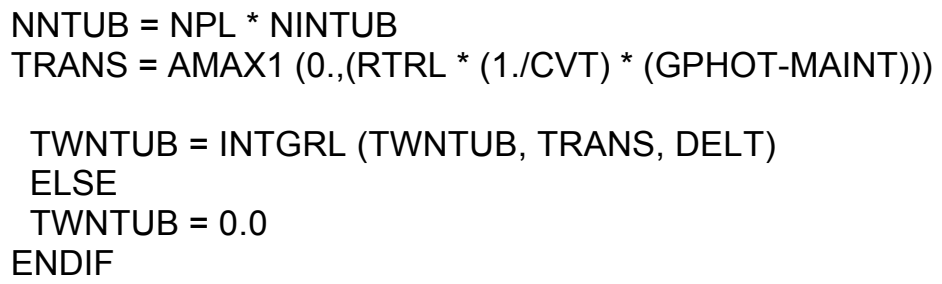

*-----When the new tuber class is finished, the new tubers are added to the total number of

* dormant tubers

NDTUB $=$ NDTUB $+($ NPL $*$ NINTUB $)$

NTUBD $=$ RDTU * NDTUB * TEFF

*-----Reset new tuber number and weight back to zero

$$
\begin{aligned}
& \text { NNTUB }=0.0 \\
& \text { TWNTUB }=0.0 \\
& \text { ENDIF }
\end{aligned}
$$

ELSE

TRANS $=0.0$

ENDIF

ELSE

TRANS $=0.0$

ENDIF

ELSE

TRANS $=0.0$

ENDIF

*-----Recalculate tuber numbers daily

IF (DAY .GT. 1.0) THEN

*-----NNTUB not added because they were included in NDTUB when reaching the total 
* critical dry weight of new tubers TWCTUB ENDIF

*-----Dry matter and its partitioning over the plant organs

$T W=T G W+(T W L V D+T W S T D+T W R T D)$

$F L V=$ LINT(FLVT, ILFLVT,DVS)

FST $=$ LINT(FSTT, ILFSTT,DVS)

FRT $=$ LINT(FRTT, ILFRTT,DVS)

$\mathrm{FL}=\mathrm{LINT}(\mathrm{FLT}, \mathrm{ILFLT}, \mathrm{DVS})$

*-----Growth of plant organs, maintenance respiration and translocation

$\mathrm{ASRQ}=1.46^{\star} \mathrm{FLV}+1.51^{\star} \mathrm{FST}+1.44^{*} \mathrm{FRT}$

MAINTS $=0.016^{*}$ TWLVG $+0.01^{*}$ TWSTG $+0.015^{*}$ TWRTG

MAINT $=$ MAINTS * TEFF

*-----Sprouting tubers die if the resulting plant biomass has a negative net photosynthesis

* during a user-defined number of consecutive days (27 is nominal). If this event

* occurs, the program stops, and writes 'SURFAC'; By pressing enter, the program

* continues

* ... KCOUNT is a counter variable, which counts the days with negative net photosynthesis

IF (GPHOT .LT. MAINT) THEN

KCOUNT $=$ KCOUNT +1

ELSE

KCOUNT $=0$

ENDIF

IF (KCOUNT.EQ.SSURPR .AND. SURFAC.LT.1.) THEN

write $\left({ }^{*},{ }^{*}\right)$ ' KCOUNT = ',KCOUNT,' SURFAC = ',SURFAC

$\operatorname{read}\left({ }^{*},{ }^{*}\right)$

TWLVD $=$ TWLVD + TWLVG

TWSTD $=$ TWSTD + TWSTG

TWRTD = TWRTD + TWRTG

TWLVG $=0.0$

TWSTG $=0.0$

TWRTG $=0.0$

REMOB $=0.0$

NDTUB = AMAX1 (0., NDTUB-NPL)

* Initialize variable(s) used in condition statement

* Tropical ... Latitude is less than or equal to $33 \mathrm{deg}$

IF (LAT .LE. 33.)THEN

VAR1 $=1.6$

ELSE

* Temperate ... Latitude is greater than 33 deg

VAR1 $=1.0$

ENDIF

*

IF (DVS .LT. VAR1 .AND. NDTUB .GT. 0.) NGTUB = NPL cPOTAMIN IF (DVS .LT. 1.0.AND. NDTUB .GT. 0.) NGTUB = NPL cPOTAMIN IF (DVS .LT. 1.6 .AND. NDTUB .GT. 0.) NGTUB $=$ NPL

ENDIF

* Initialize variable(s) used in condition statement 
* Tropical ... Latitude is less than or equal to 33 deg IF (LAT .LE. 33.)THEN

VAR1 $=3.2$

ELSE

* Temperate ... Latitude is greater than 33 deg

VAR1 $=2.001$

ENDIF

*

*-----Relative death rates RDR = INSW (DVS-VAR1,0.,LINT (RDRT,ILRDRT,DAVTMP))

RDS = INSW (DVS-VAR1,0.,LINT (RDST,ILRDST,DAVTMP))

cPOTAMIN RDR = INSW (DVS-2.001,0.,LINT (RDRT, ILRDRT,DAVTMP))

cPOTAMIN RDS = INSW (DVS-2.001,0.,LINT (RDST,ILRDST,DAVTMP))

CPOTAMIN RDR = INSW (DVS-3.2,0.,LINT (RDRT,ILRDRT,DAVTMP))

cPOTAMIN RDS = INSW (DVS-3.2,0.,LINT (RDST,ILRDST,DAVTMP))

*-----Development rates

* Initialize variable(s) used in condition statement

* Tropical ... Latitude is less than or equal to $33 \mathrm{deg}$

IF (LAT .LE. 33.)THEN

VAR1 $=1.6$

$\operatorname{VAR} 2=20.0$

ELSE

* Temperate ... Latitude is greater than $33 \mathrm{deg}$

VAR $1=1.0$

VAR2 $=20.0$

ENDIF

*

IF(DAVTMP .LT. 3.0) THEN

DVR $=0.0$

ELSE IF (DVS .LE. VAR1) THEN

CPOTAMIN ELSE IF (DVS.LE.1.) THEN

CPOTAMIN ELSE IF (DVS.LE.1.6) THEN

DVR $=0.015^{\star}$ DAVTMP $/ 30$

ELSE IF (DVS .GT. VAR1 .AND. DVS .LT. VAR2) THEN

CPOTAMIN ELSE IF (DVS.GT.1. .AND. DVS .LT. 20.0) THEN

CPOTAMIN ELSE IF (DVS.GT.1.6 .AND. DVS .LT. 20.0) THEN

DVR $=0.040 *$ DAVTMP $/ 30$

ENDIF

*-----Calculation of astronomic day length

CALL ASTRO

\$ (DAY,LAT,SC,DS0,SINLD,COSLD,DAYL,DSINB,DSINBE)

*-----Daily temperature after 1.January, with base temperature

* specified by user (given in MODEL.DAT)

DTEFF = AMAX1(0.,DAVTMP-TBASE)

*-----Calculation quantities dead plant material

$$
\begin{aligned}
\text { DLV } & =\text { TWLVG }{ }^{*} \text { RDR } \\
\text { DST } & =\text { TWSTG }{ }^{*} \text { RDR } \\
\text { DRT } & =\text { TWRTG * RDR }
\end{aligned}
$$

*-----Shoot photosynthesis at light saturation and daytime temperature effect on shoot photosynthesis AMAX = AMAX1 $(0.00001, A M X * A M T M P)$ 
$A M A X=A M A X *$ REDAM

AMTMP $=$ LINT(AMTMPT, ILAMTM,DDTMP)

*-----Before calling TOTASS, determine light extinction coefficients of plants $(\mathrm{K})$ and of water $(\mathrm{L})$ $\mathrm{L}=\mathrm{LINT}(\mathrm{LT}, \mathrm{ILT}, \mathrm{TIME})$

$\mathrm{K}=\mathrm{LINT}(\mathrm{KT}, \mathrm{IKT}, \mathrm{DVS})$

*-----Daily total gross assimilation

CALL TOTASS

\$ (SC,DAYL,SINLD,COSLD,DSINBE,RDD,RC,L,K,AMAX,EE,

\$ TL,DPT,RCSHST,TGW,FGROS,FL,FLV,FRT,FST,WLV,WST,

\$ DAY,HAR,HARDAY,HARDEP,DTGA,NPL,IRS,REMOB,TWLVG,

\$ TWSTG,TWRTG,SURFAC,CRIFAC)

*------If DVS is greater than one then REMOB should be set to zero

* Initialize variable(s) used in condition statement

* Tropical ... Latitude is less than or equal to $33 \mathrm{deg}$

IF (LAT .LE. 33.)THEN

VAR1 $=1.6$

ELSE

* Temporate ... Latitude is greater than $33 \mathrm{deg}$

VAR1 $=1.0$

ENDIF

*

IF (DVS .GE. VAR1) REMOB $=0.0$

CPOTAMIN IF (DVS.GE. 1.) REMOB $=0.0$

cPOTAMIN IF (DVS .GE. 1.6) REMOB $=0.0$

*-----If harvesting takes place, weights various plant organs must be recalculated;

these are :TWLVG, TWSTG, TWRTG,TW

IF(HAR .EQ. 1. AND. DAY .EQ. HARDAY) THEN

$T W L V G=F L V * T G W$

TWSTG $=$ FST $*$ TGW

TWRTG $=$ FRT $*$ TGW

$T W=T G W+(T W L V D+T W S T D+T W R T D)$

ENDIF

*-----Conversion assimilated $\mathrm{CO} 2$ to $\mathrm{CH} 2 \mathrm{O}$

GPHOT $=$ DTGA * 30./44.

*-----Total and net growth rates

GTW $=\left(\left(\right.\right.$ REMOB ${ }^{*}$ CVT $)+$ GPHOT - TRANS - MAINT $) / A S R Q$

$\mathrm{GRT}=\mathrm{FRT}{ }^{*} \mathrm{GTW}$

$\mathrm{GST}=\mathrm{FST} * \mathrm{GTW}$

$\mathrm{GLV}=\mathrm{FLV} * \mathrm{GTW}$

NGLV = GLV - DLV

NGST $=$ GST - DST

NGRT $=$ GRT - DRT

*-----Finish conditions

IF (DVS.GT.20.0 .OR. DAY .EQ. 365.) TERMNL = .TRUE.

*-----Output section 
IF (OUTPUT) THEN

CALL OUTDAT $(2,0$, 'DAVTMP',DAVTMP)

CALL OUTDAT $(2,0$, ,'DAYL ',DAYL )

CALL OUTDAT (2,0,'DDTMP',DDTMP )

CALL OUTDAT (2,0,'DPT ',DPT )

CALL OUTDAT (2,0,'DTGA ',DTGA )

CALL OUTDAT (2,0,'DTEFF ',DTEFF )

CALL OUTDAT (2,0,'DVS ',DVS )

CALL OUTDAT (2,0,'FGROS ',FGROS )

CALL OUTDAT $(2,0$, 'GPHOT ',GPHOT )

CALL OUTDAT $(2,0$, 'IRS ',IRS )

CALL OUTDAT $(2,0$, 'MAINT ',MAINT )

CALL OUTDAT $(2,0$, 'NDTUB ',NDTUB )

CALL OUTDAT $(2,0$, 'NGTUB ',NGTUB )

CALL OUTDAT (2,0,'NNTUB ',NNTUB )

CALL OUTDAT $(2,0$, 'NTM ',NTM )

CALL OUTDAT (2,0,'NTUBD ',NTUBD )

CALL OUTDAT $(2,0$, 'REMOB ',REMOB )

CALL OUTDAT $(2,0$, 'TEFF ',TEFF )

CALL OUTDAT $(2,0$, 'TGW ',TGW )

CALL OUTDAT (2,0,'TGWM ',TGWM )

CALL OUTDAT (2,0,'TRANS ',TRANS )

CALL OUTDAT $(2,0$, ,'TREMOB',TREMOB)

CALL OUTDAT $(2,0$, ,'TW ',TW )

CALL OUTDAT $(2,0$, 'TWCTUB', TWCTUB)

CALL OUTDAT (2,0,'TWGTUB', TWGTUB)

CALL OUTDAT (2,0,'TWLVD ',TWLVD )

CALL OUTDAT $(2,0$, 'TWLVG ',TWLVG )

CALL OUTDAT $(2,0$, 'TWNTUB', TWNTUB)

CALL OUTDAT (2,0,'TWRTD ',TWRTD )

CALL OUTDAT (2,0,'TWRTG ',TWRTG )

CALL OUTDAT (2,0,'TWSTD ',TWSTD )

CALL OUTDAT $(2,0$, 'TWSTG ',TWSTG )

CALL OUTDAT $(2,0, ' T W T U B$ ',TWTUB )

CALL OUTDAT (2,0,'TWTUBD',TWTUBD)

CALL OUTDAT (2,0,'WTMP ',WTMP )

END IF

ELSE IF (ITASK.EQ.3) THEN

*

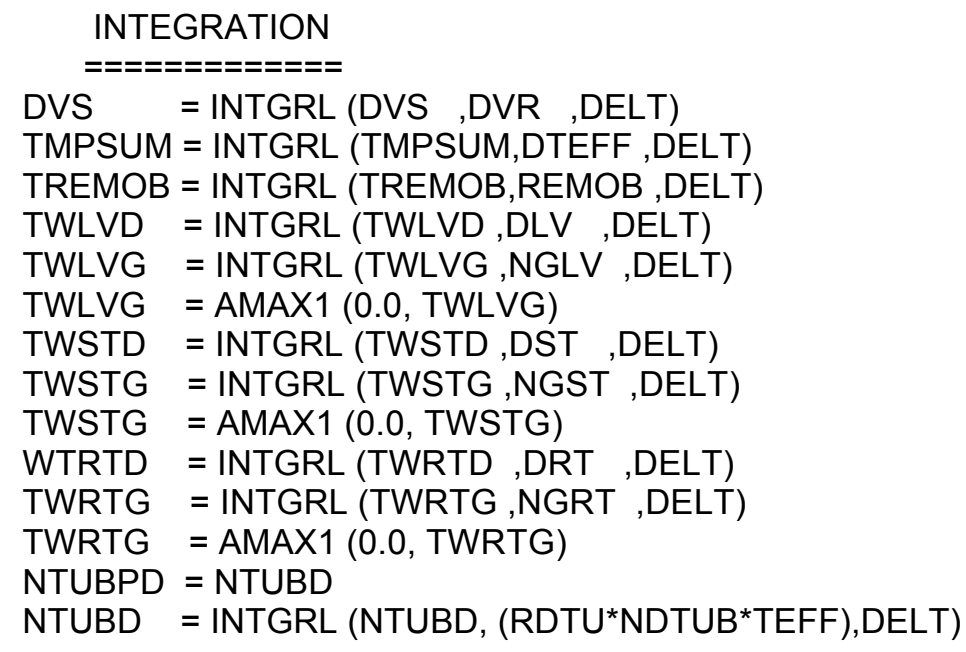




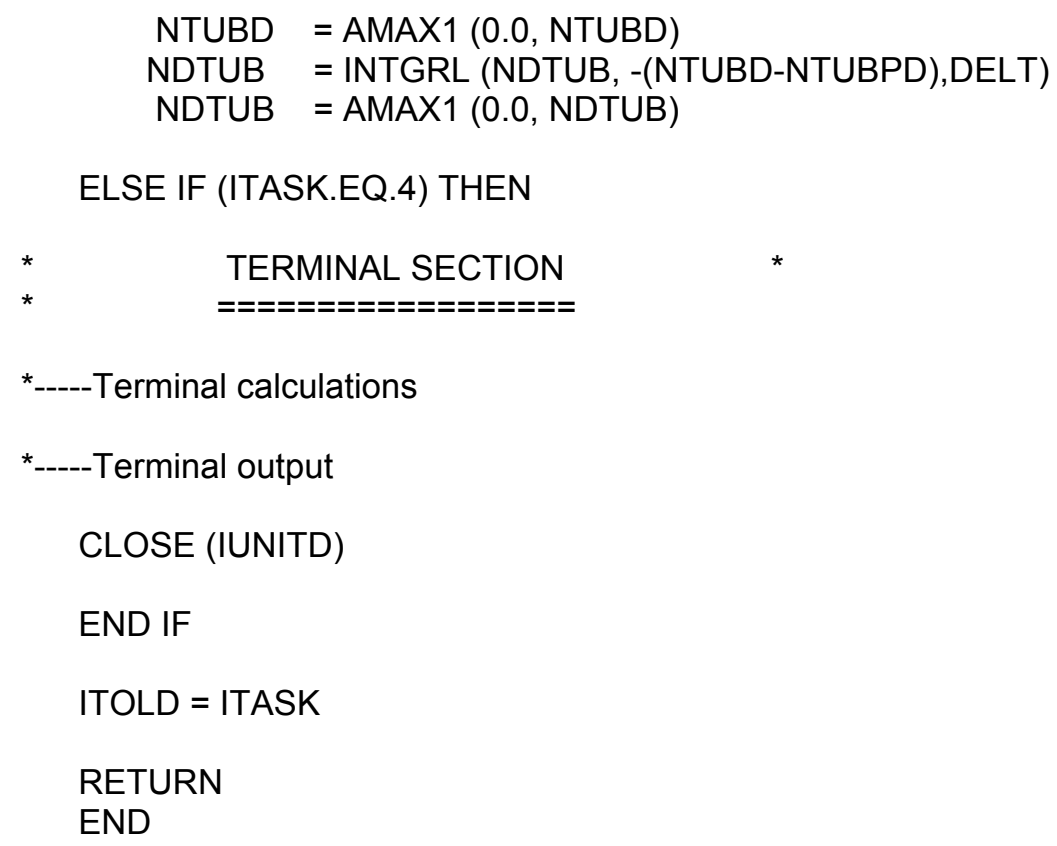



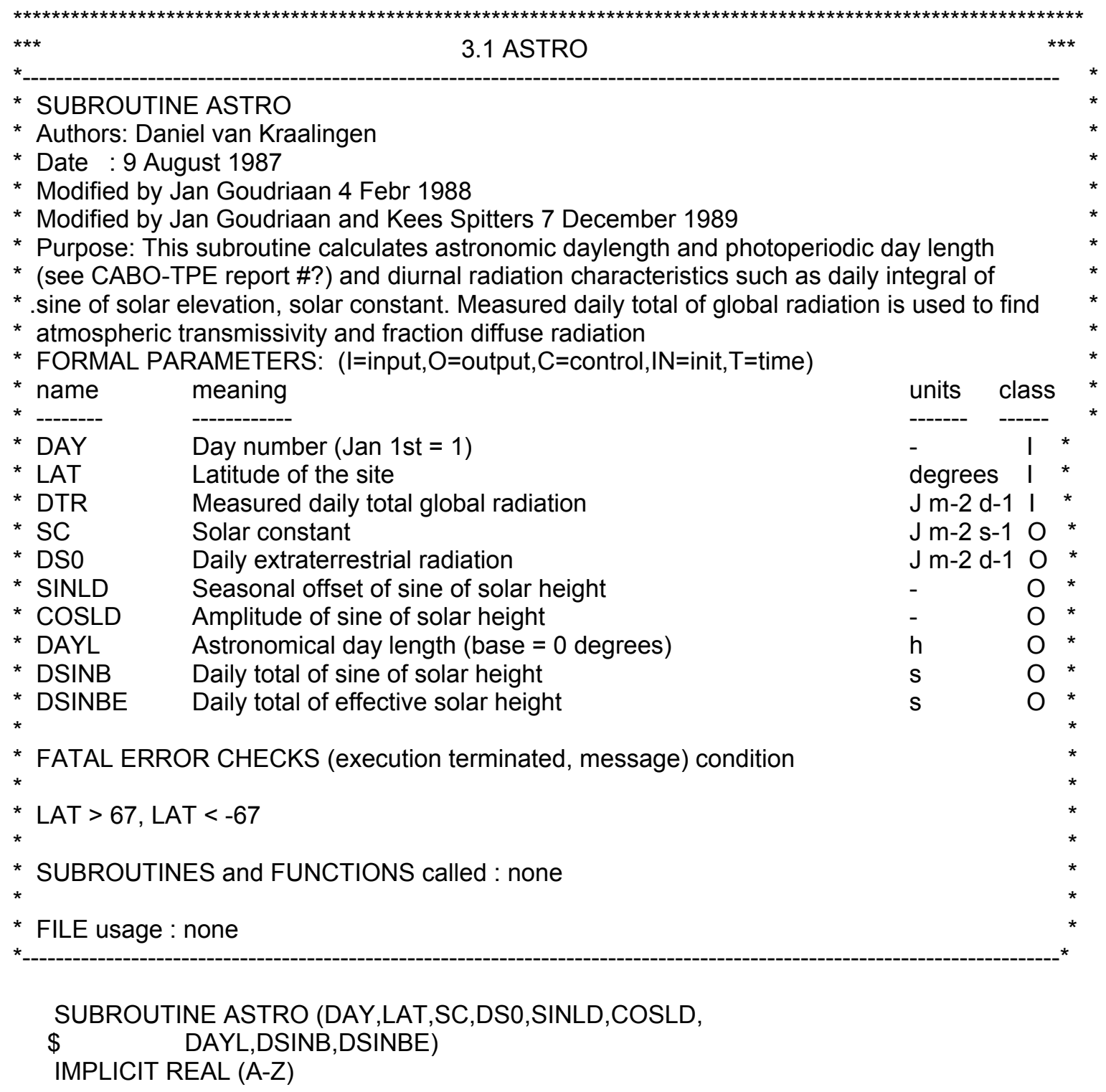

*-----PI and conversion factor from degrees to radians

PARAMETER $(\mathrm{PI}=3.141592654, \mathrm{RAD}=0.017453292)$

*-----Check on input range of parameters

IF (LATITUDEGT.67.) STOP 'ERROR IN ASTRO: LAT > 67'

IF (LATITUDELT.-67.) STOP 'ERROR IN ASTRO: LAT <-67'

*-----Declination of the sun as function of daynumber (DAY)

$\mathrm{DEC}=-\mathrm{ASIN}\left(\operatorname{SIN}\left(23.45^{*} \mathrm{RAD}\right){ }^{*} \mathrm{COS}\left(2 .{ }^{*} \mathrm{PI}^{*}(\mathrm{DAY}+10) / 365.\right)\right)$

*-----SINLD, COSLD and AOB are intermediate variables

SINLD $=$ SIN $(R A D * L A T) * S I N(D E C)$

COSLD $=\operatorname{COS}\left(\mathrm{RAD}^{*} \mathrm{LAT}\right)^{*} \mathrm{COS}(\mathrm{DEC})$

$A O B=S I N L D / C O S L D$

*-----Daylength (DAYL)

$\mathrm{DAYL}=12.0^{*}\left(1 .+2 .{ }^{*} \mathrm{ASIN}(\mathrm{AOB}) / \mathrm{PI}\right)$ 


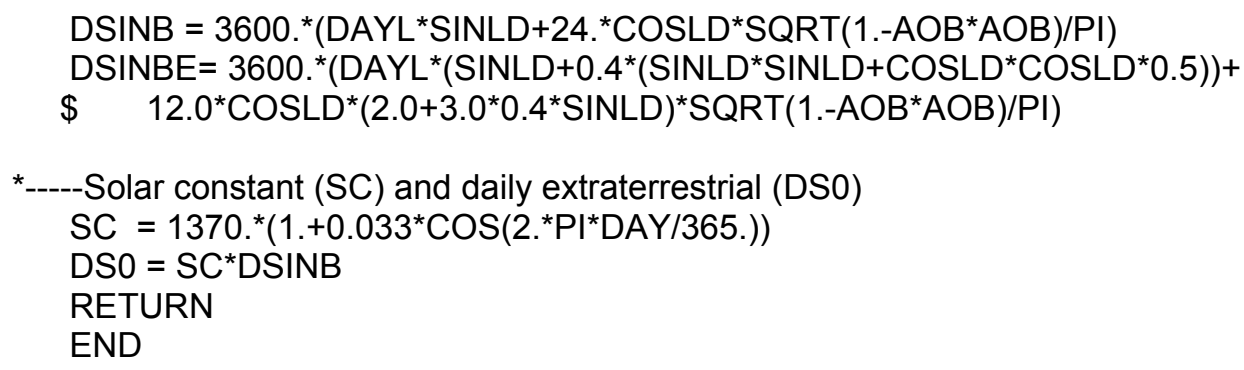




\begin{tabular}{|c|c|c|c|c|c|}
\hline \multicolumn{6}{|c|}{$* * * \quad 3.2$ TOTASS } \\
\hline \multirow{12}{*}{\multicolumn{5}{|c|}{$\begin{array}{l}\text { * SUBROUTINE TOTASS } \\
\text { * Authors: Daniel van Kraalingen } \\
\text { * Date : } 1 \text { December } 1987 \\
\text { * Modified by Jan Goudriaan 5-Febr-1988 } \\
\text { * Modified by Jan Goudriaan and Kees Spitters } 7 \text { December } 1989 \\
\text { * Units modified by Elly Best \& Will Boyd } 28 \text { July } 1995 \\
\text { * Purpose: This subroutine calculates daily total gross assimilation (DTGA) by } \\
\text { * performing a Gaussian integration over time. At three different times of the day, } \\
\text { *..radiation is computed and used to determine assimilation whereafter integration } \\
\text { * takes place.(Source: Post-graduate Course 'Simulation of plant growth and crop } \\
\text { * production. Pontignano, Siena, Italy; } 3-12 \text { November, 1992. Dept. Theor. } \\
\text { * Production Ecol. (TPE-WAU), Wageningen Agricultural University, and DLO-Centre } \\
\text { * for Agrobiological Research (CABO-DLO).) } \\
\text { * }\end{array}$}} & * \\
\hline & & & & & * \\
\hline & & & & & $*$ \\
\hline & & & & & $*$ \\
\hline & & & & & 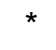 \\
\hline & & & & & \\
\hline & & & & & \\
\hline & & & & & \\
\hline & & & & & \\
\hline & & & & & \\
\hline & & & & & \\
\hline & & & & & \\
\hline \multicolumn{6}{|c|}{ * FORMAL PARAMETERS: (I=input, $\mathrm{O}=$ output, $\mathrm{C}=$ control, $\mathrm{IN}=$ init, $\mathrm{T}=$ time $)$} \\
\hline * name & meaning & & units & class & \\
\hline * SC & So & & $\mathrm{J} \mathrm{m}-2 \mathrm{~s}-1$ & & 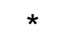 \\
\hline * DAYL & ase & & & I & * \\
\hline * SINLD & ating sol & & & & \\
\hline * COSLD & Inte & & - & I & * \\
\hline * DSINBE & Daily & & & I & 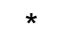 \\
\hline * DTR & ation & & $\mathrm{J} \mathrm{m}-2 \mathrm{~d}-1$ & & \\
\hline * $\mathrm{RC}$ & $\mathrm{Re}$ & & & I & * \\
\hline * $L$ & & & - & I & * \\
\hline * $\mathrm{K}$ & & & - & & \\
\hline * AMAX & individual shoots & $\mathrm{g} \mathrm{CC}$ & $\mathrm{DW} / \mathrm{h}$ & I & \\
\hline * $\mathrm{EE}$ & y for individual shoots & gC & & I & 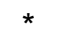 \\
\hline * $\overline{T L}$ & plant layer & & $\mathrm{m}$ & I & 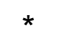 \\
\hline * DPT & & & $\mathrm{m}$ & I & 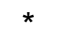 \\
\hline * RCHSHST & $\mathrm{Re}$ & & & I & * \\
\hline * $T$ & & & & I & \\
\hline * FGR & Ins & & /m2 soil/ & & \\
\hline * $\mathrm{FL}$ & Lea & & - & I & \\
\hline * FLV & Fra & & - & I & ${ }^{\star}$ \\
\hline * FRT & $\mathrm{Fr}$ & & - & I & 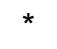 \\
\hline * FST & $\mathrm{Fr}$ & & - & & \\
\hline * WLV & $\mathrm{Dr}$ & & & I & * \\
\hline$* \mathrm{~h}$ & tems & & & & \\
\hline * HAR & Har & & - & & \\
\hline * HARDAY & mber & & d & I & \\
\hline * HARDEP & $\mathrm{Ha}$ & & $\mathrm{m}$ & & \\
\hline * DTGA & Daily total gross assimilation & $\mathrm{g} \mathrm{C}$ & $m-2 d-1$ & & \\
\hline * NPL & Plant & & plants $\mathrm{m}$ & & \\
\hline * IRS & Toté & & $\mathrm{J} \mathrm{m}-2 . \mathrm{s}-1$ & & * \\
\hline * REMOB & Remobilization rates of carbohydrates & & $N \mathrm{~m}-2 \mathrm{~d}-1$ & & \\
\hline * TWLVG & Total dry weight of live leaves & & g DW m- & & \\
\hline * TWSTG & Total dry weight of live stems & & g D & & \\
\hline * TWRTG & Total dry weight of live roots & & g DW m- & & \\
\hline * SURFAC & $\begin{array}{l}\text { Expression of warning that plant canopy is not at } \\
\text { surface and tuber class has died }\end{array}$ & & - & & * \\
\hline * CRIFAC & Critical weight per $0.1 \mathrm{~m}$ plant layer & & gDV & & \\
\hline
\end{tabular}


* SUBROUTINES and FUNCTIONS called : ASSIM

*

* FILE usage : none

SUBROUTINE TOTASS (SC,DAYL,SINLD,COSLD,DSINBE,DTR,RC,L,K,

$\$$ AMAX,EE,TL,DPT,RCSHST,TGW,FGROS,FL,

\$ FLV,FRT,FST,WLV,WST,DAY,HAR,HARDAY,

\$ HARDEP,DTGA,NPL,IRS,REMOB,TWLVG,TWSTG,

\$ TWRTG,SURFAC,CRIFAC)

IMPLICIT REAL(A-Z)

REAL XGAUSS(3), WGAUSS(3)

INTEGER II, IGAUSS

PARAMETER $(\mathrm{PI}=3.141592654)$

DATA IGAUSS / $3 /$

DATA XGAUSS / $0.1127,0.5000,0.8873 /$

DATA WGAUSS /0.2778, 0.4444, 0.2778/

*-----Assimilation set to zero \& three different times of the day (HOUR)

DTGA $=0$.

DO $10 \|=1$, IGAUSS

*-----At the specified HOUR, radiation is computed and used to compute assimilation HOUR $=12.0+D A Y L^{*} 0.5^{*}$ XGAUSS $(I I)$

*-----Sine of solar elevation

$\operatorname{SINB}=\operatorname{AMAX} 1\left(0 ., \operatorname{SINLD}+\operatorname{COSLD}{ }^{*} \operatorname{COS}\left(2 .{ }^{*} \mathrm{PI}^{*}(\mathrm{HOUR}+12) / 24.\right)\right)$

*-----Diffuse light fraction (FRDIF) from atmospheric transmission (ATMTR)

PAR $=0.5^{*} \mathrm{DTR}^{*} \mathrm{SINB}^{*}\left(1 .+0.4^{*} \mathrm{SINB}\right) / \mathrm{DSINBE}$

ATMTR $=$ PAR $/\left(0.5^{*} S C^{*}\right.$ SINB $)$

FRDIF $=1.47-1.66^{*} A T M T R$

IF (ATMTR.LE.0.35.AND.ATMTR.GT.0.22) FRDIF=1.-6.4*(ATMTR-0.22) ${ }^{* *} 2$

IF (ATMTR.LE.0.22) FRDIF=1.

FRDIF $=$ AMAX1 $\left(F R D I F, 0.15+0.85^{*}(1 .-E X P(-0.1 / S I N B))\right)$

*-----Diffuse PAR (PARDIF) and direct PAR (PARDIR)

$P A R=0.5^{*} D_{T R}^{*} \operatorname{SINB}^{*}\left(1 .+0.4^{*} \mathrm{SINB}\right) / \mathrm{DSINBE}$

PARDIF $=$ MIN $\left(P A R, S I N B^{*} F R D I F^{*} A_{T M T R}^{*} 0.5^{\star} S C\right)$

PARDIR = PAR-PARDIF

CALL ASSIM

\$ (PARDIR,PARDIF,RC,L,K,AMAX,EE,TL,DPT,RCSHST,TGW,

\$ FL,FLV,FRT,FST,WLV,WST,DAY,HAR,HARDAY,HARDEP,II,FGROS,NPL,IRS,

\$ REMOB,TWLVG,TWSTG,TWRTG,SURFAC,CRIFAC)

*-----Integration of assimilation rate to a daily total (DTGA)

DTGA = DTGA+FGROS*WGAUSS(II)

10 CONTINUE

DTGA $=$ DTGA*DAYL 
RETURN

END

\begin{tabular}{|c|c|c|c|c|}
\hline *** & 3.3 ASSIM & & & * \\
\hline * & & & & \\
\hline Authors: Ell & Best \& Will Boyd & & & \\
\hline Date : 28 & ly 1995 & & & * \\
\hline $\begin{array}{l}\text { Purpose: T } \\
\text { in the wat }\end{array}$ & s subroutine performs an instantaneous calculation of light $p$ & brofile & & \\
\hline * assimilatic & at all these depth layers. The depth-integrated variable is $F$ & GROS. At & & \\
\hline harvesting & the plant material is removed per depth layer from the ex & ng biomass & & \\
\hline FORMAL & RAMETERS: (I=input, $\mathrm{O}=$ output, $\mathrm{C}=$ control, $\mathrm{IN}=$ init, $\mathrm{T}=$ time $)$ & & & * \\
\hline name & meaning & units & class & * \\
\hline * PARDIR & Instantaneous flux of direct radiation (PAR) & W m-2 & 1 & * \\
\hline * PARDIF & Instantaneous flux of diffuse radiation(PAR) & $\mathrm{W} \mathrm{m}-2$ & i & . \\
\hline * $\mathrm{RC}$ & Reflection coefficient of irradiation at water surface & - & I & * \\
\hline * $\mathrm{L}$ & Water type specific light extinction coefficient & $m-1$ & I & * \\
\hline * $\mathrm{K}$ & Plant species specific light extinction coefficient & m2 g-1DW & I & * \\
\hline * AMAX & Assimilation rate at light saturation for individual shoots & $\mathrm{g} \mathrm{CO} 2 / \mathrm{g} \mathrm{DW} / \mathrm{h}$ & & * \\
\hline * EE & Initial light use efficiency for individual shoots & g CO2 J-1 & & * \\
\hline * TL & Thickness per plant layer & $\mathrm{m}$ & I & * \\
\hline * DPT & Water depth & $\mathrm{m}$ & i & * \\
\hline * RCHSHST & Relation coefficient tuber weight-stem length & $\mathrm{m} / \mathrm{g} \mathrm{DW}$ & & * \\
\hline * TGW & Total live plant dry weight & g DW m-2 & & \\
\hline${ }^{*} \mathrm{FL}$ & Leaf dry matter allocation to each layer of plant & - & I & * \\
\hline * FLV & Fraction of total dry matter increase allocated to leaves & - & I & * \\
\hline * FST & Fraction of total dry matter increase allocated to stems & - & I & * \\
\hline * WLV & Dry weight of leaves & g DW m-2 & & \\
\hline * WST & Dry weight of stems & g DW m-2 & & \\
\hline * HAR & Harvesting & - & I & \\
\hline * HARDAY & Harvesting day number & $d$ & I & \\
\hline * HARDEP & Harvesting depth & $\mathrm{m}$ & I & \\
\hline * II & Counter in DO LOOP, indicates 1 of 3 times per day (HOUF & R) & I & \\
\hline * FGROS & Instantaneous assimilation rate of the plant & $\mathrm{g} \mathrm{CO} 2 / \mathrm{m} 2 / \mathrm{h}$ & & \\
\hline * NPL & Plant density & plants $\mathrm{m}-2$ & I & \\
\hline * IRS & Total irradiance just under the water surface & $\mathrm{J} \mathrm{m}-2 \mathrm{~s}-1$ & & \\
\hline * REMOB & Remobilization rates of carbohydrates & g DW $m-2 d-1$ & & * \\
\hline * TWLVG & Total dry weight of live leaves & g DW m-2 & & * \\
\hline * TWSTG & Total dry weight of live stems & g DW m-2 & & * \\
\hline * TWRTG & Total dry weight of live roots & g DW m-2 & & * \\
\hline * SURFAC & $\begin{array}{l}\text { Expression of warning that plant canopy is not at } \\
\text { water surface and tuber class has died }\end{array}$ & - & & * \\
\hline * CRIFAC & Critical weight per $0.1 \mathrm{~m}$ plant layer & $\mathrm{gDW} / 0.1 \mathrm{~m}$ & & * \\
\hline & & plnt ht per pln & & \\
\hline SI & ES called : none & & & \\
\hline * FUNCTION & called : AFGEN & & & * \\
\hline FILE usage & one & & & * \\
\hline
\end{tabular}


SUBROUTINE ASSIM (PARDIR,PARDIF,RC,L,K,AMAX,EE,TL,

$\begin{array}{ll}\$ & \text { DPT, RCSHST,TGW,FL,FLV,FRT,FST, } \\ \$ & \text { WLV,WST,DAY,HAR,HARDAY,HARDEP,II, } \\ \$ & \text { FGROS,NPL,IRS,REMOB,TWLVG,TWSTG, } \\ \$ & \text { TWRTG,SURFAC,CRIFAC) }\end{array}$

IMPLICIT REAL(A-Z)

REAL DMPC(5), SC(100), IRZ(100), IABS(100), IABSL(100)

REAL HIG(100), AH(100), REDF(100), SumZ

INTEGER IMN1, IRED, I, LOOP, Layers, LBelow, ILAY, II, MM

PARAMETER $($ IMN1 $=40)$

REAL REDFT(IMN1), DMPCT(IMN1)

*-----Read AFGEN functions

CALL RDAREA ('REDFT ',REDFT ,IMN1, ,IRED )

CALL RDAREA ('DMPCT ',DMPCT, IMN1 ,ILAY )

*-----Irradiation just beneath the water surface

IRS = PARDIR + PARDIF

$\operatorname{IRZ}(1)=\operatorname{IRS} *(1.0-\mathrm{RC})$

*-----Set a critical shoot weight for each depth layer

CRIGWT = CRIFAC * NPL

*-----Canopy assimilation is set to zero

FGROS $=0$.

*-----Calculate stem length

STEMLE = AMIN1 $\left(\right.$ DPT+.0995, $\left(\right.$ RCSHST $\left.\left.^{*}(\mathrm{WLV}+\mathrm{WST})\right)\right)$

*-----Calculate shoot biomass

SHTBIO = TWLVG + TWSTG

IF (STEMLE .GT. DPT+.08)THEN

*-----Determine total number of layers in the given water depth LOOP $=$ INT $(\mathrm{DPT} / \mathrm{TL}+0.1)+1$

*-----Water depth must be $>0.8 \mathrm{~m}$ to use this distribution

* method; otherwise, go to ELSE which will distribute biomass equally IF (LOOP .GT. 9) THEN

*-----If the biomass per layer is $>$ or $=$ the critical weight, proceed as usual IF ((SHTBIO/(LOOP-1)) .GE. CRIGWT) THEN

*-----Since plant biomass has reached the surface REMOB becomes zero

$\mathrm{REMOB}=0.0$

SURFAC $=1$.

*-----Initialize variable for sum of percent biomass in 1 st 5 layers FIRST5 $=0.0$

*-----Distribute 78.4 percent of total plant biomass in 1st 5 layers

** $\quad$ write $\left({ }^{*},{ }^{*}\right)$ ' Total weight $=$ ',TGW

DO $10 \mathrm{I}=1,5$

$\mathrm{VAL}=\mathrm{REAL}(\mathrm{I})$ 
$\operatorname{DMPC}(I)=$ LINT $(D M P C T, I L A Y, V A L)$

*-----Sum of percent biomass in the 1 st 5 layers FIRST5 = FIRST5 + DMPC $(I)$

$\mathrm{SC}(\mathrm{I})=\mathrm{TGW} * \mathrm{DMPC}(\mathrm{I})$

** write $\left({ }^{*},{ }^{*}\right)$ ' layer ',l,' = ',SC(I)

10 CONTINUE

*-----Determine percent biomass distributed over the lower layers PCTLOW = $1.0-($ FIRST5 + FRT $)$

*-----Distribute 13 percent of biomass in the lower layers (excluding last layer)

* with biomass gradually decreasing toward the bottom

* LOOP (integer) .. Number of $0.1 \mathrm{~m}$ water layers

* LAYERS (integer) .. Layers remaining after initial 5

*-----SUMZ (real) .. Summation of layers 6 through LOOP

*-----LBELOW (integer) .. Layer number going from bottom to top

*-----6 Is the 1st 5 layers + the bottom 1 layer (roots)

LAYERS $=$ LOOP -6

SUMZ $=\left(\right.$ LAYERS/2.0) ${ }^{*}($ LAYERS +1.0$)$

DO $20 \mathrm{I}=6$, LOOP -1

LBELOW = LAYERS $-(I-5)+1.0$

$\mathrm{SC}(\mathrm{I})=($ LBELOW/SUMZ $) *(T G W *$ PCTLOW $)$

20 CONTINUE

*-----If not enough biomass per layer .. take away layers until enough

ELSE

LESS $=1$

23 LESS $=$ LESS +1

*-----Initialize all layers at 0.0

DO $25 \mathrm{MM}=1$, LOOP -1

$\mathrm{SC}(\mathrm{MM})=0.0$

25 CONTINUE

*-----If critical biomass is not met ... go back to 23 \& remove a layer

IF ((SHTBIO/(LOOP-LESS)).LT.CRIGWT .AND. LOOP-LESS.GT.1)GOTO 23

*-----Otherwise distribute shoot biomass over the layers it can reach

*-----Loop goes from bottom to top ... i.e. $10,9,8, \ldots, 2,1$

SURFAC $=0$.

DO $27 \mathrm{MM}=$ LOOP-1,LESS,-1

SC $(M M)=$ AMIN1 $(C R I G W T$, SHTBIO)

IF (SHTBIO .GT. CRIGWT) SC(MM-1) = SHTBIO - CRIGWT

IF (SHTBIO .GT. CRIGWT) SHTBIO = SHTBIO - CRIGWT

27 CONTINUE

ENDIF

ELSE

*-----If water depth is $0.8 \mathrm{~m}$ or less, plant biomass is distributed evenly over the existing layers 
*-----If biomass reaches the surface ... proceed as usual

IF (SHTBIO/(LOOP-1) .GE. CRIGWT) THEN

SURFAC $=1$.

DO 32 I = 1,LOOP -1

$\mathrm{SC}(\mathrm{I})=\mathrm{SHTBIO} /(\mathrm{LOOP}-1)$

** $\quad$ write $\left({ }^{*},\right)^{*}$ layer $', \mathrm{l},,^{\prime}=$ ',SC (I)

32 CONTINUE

ELSE

*-----If biomass does not reach the surface

LESS $=1$

33 LESS $=$ LESS +1

*-----Initialize all layers at 0.0

DO $35 \mathrm{MM}=1$, LOOP -1

$\mathrm{SC}(\mathrm{MM})=0.0$

35 CONTINUE

*-----If critical biomass is not met ... go back to 33 \& remove a layer

IF ((SHTBIO/(LOOP-LESS)).LT.CRIGWT .AND. LOOP-LESS.GT.1)GOTO 33

*-----Otherwise distribute shoot biomass over the layers it can reach

*-----Loop goes from bottom to top ... i.e. 8,7,6, ..,2,1

SURFAC $=0$.

DO $37 \mathrm{MM}=$ LOOP-1,LESS, -1

$\mathrm{SC}(\mathrm{MM})=\mathrm{AMIN} 1(\mathrm{CRIGWT}, \mathrm{SHTBIO})$

IF (SHTBIO .GT. CRIGWT) SC(MM-1) = SHTBIO - CRIGWT

IF (SHTBIO .GT. CRIGWT) SHTBIO = SHTBIO - CRIGWT

37 CONTINUE

CC $\quad$ DO $38 \mathrm{MM}=1, \mathrm{LOOP}-1$

CC write $\left(*,{ }^{*}\right)$ ' layer $=$ ',MM,' biomass $=$ ',SC $(\mathrm{MM})$

CC 38 CONTINUE

CC $\operatorname{read}\left({ }^{*},{ }^{*}\right)$

ENDIF

ENDIF

*-----Distribute 8.6 percent of biomass in the last layer (roots)

SC $($ LOOP $)=$ TWRTG

** $\quad$ write $\left({ }^{*},{ }^{*}\right)$ ' layer ',LOOP,' = ',SC(LOOP)

** $\operatorname{read}\left({ }^{*}, *\right)$

*-----Harvesting

IF (HAR .EQ. 1. .AND. DAY .EQ. HARDAY)THEN

IF (HARDEP .GT. DPT) HARDEP = DPT

DO $45 \mathrm{I}=1$, (HARDEP/TL+1.0)

$\mathrm{SC}(\mathrm{I})=0.0$

45 CONTINUE

*-----Reset total live weight (TGW) to zero

IF(II .EQ. 1)TGW = 0.0

ENDIF 
DO $60 \mathrm{I}=1, \mathrm{LOOP}$

*-----Total irradiation on top of stratum I

$\operatorname{IRZ}(I+1)=\operatorname{IRZ}(\mathrm{I}){ }^{*} \operatorname{EXP}\left(-\mathrm{TL}^{*} \mathrm{~L}-\mathrm{K}^{*} \mathrm{SC}(\mathrm{I})\right)$

IF(SC(I) .EQ. 0.0) GOTO 48

*-----Radiation absorbed by macrophyte community

$\operatorname{IABS}(\mathrm{I})=(\operatorname{IRZ}(\mathrm{I})-\mathrm{IRZ}(\mathrm{I}+1))^{*} \mathrm{SC}(\mathrm{I})^{*} \mathrm{~K} /\left(\mathrm{K}^{*} \mathrm{SC}(\mathrm{I})+\mathrm{TL}{ }^{*} \mathrm{~L}\right)$

*-----Radiation absorbed by leaves, excluding bottom layer

IF(I .LT. LOOP) IABSL(I) = IABS $(I){ }^{*} \mathrm{FL}$

IF(IABSL(I) .EQ. 0.0)GOTO 48

*-----Height on top of stratum I measured from the water surface $\mathrm{HIG}(\mathrm{I})=\mathrm{TL}$ * $($ LOOP $-\mathrm{I})$

*-----Absolute height of vegetation on top of stratum I, measured

* from the top of the plant

$A H(I)=S T E M L E-H I G(I)$

*-----Reduction factor over the vertical of the vegetation

$\operatorname{REDF}(\mathrm{I})=\mathrm{LINT}(\mathrm{REDFT}, \mathrm{IRED}, \mathrm{AH}(\mathrm{I}))$

*-----Instantaneous $\mathrm{CO} 2$ assimilation rate per depth layer

$F G L=S C(I)^{*} A M A X^{*} R E D F(I)^{*}\left(1 .-E X P\left(-E E^{*} \mid A B S L(I)^{*} 3600 . ~ /\right.\right.$

$\left.\left.\$\left(\operatorname{AMAX}{ }^{*} \operatorname{REDF}(\mathrm{I})^{\star} \mathrm{SC}(\mathrm{I})\right)\right)\right)$

GOTO 50

$48 \mathrm{FGL}=0.0$

$50 \mathrm{FGROS}=\mathrm{FGROS}+\mathrm{FGL}$

*-----If plants are harvested, live plant weight is recalculated

IF (HAR.EQ.1 .AND. DAY.EQ.HARDAY .AND. II.EQ.1) THEN

TGW $=$ TGW + SC $(I)$

ENDIF

60 CONTINUE

ENDIF

RETURN

END

* Model data file generated by FST translator version 1.15 TEST

* contains:

* - Initial constants as far as specified with INCON statements,

* - Model parameters,

* - AFGEN functions,

* - A SCALE array in case of a general translation

* File name: MODELPO.DAT; input MODEL.DAT file for calibration run of POTAM

* Calibration data Zandvoort Canals (Appendix C); weather file NLD4.987 pertaining

* to De Bilt, The Netherlands, 1987. LT=1.07; air temperature

* Date: 24 January 2000

* Time: 17:00:00 


\footnotetext{
* Initial constants$$
\text { INTUB }=0.083
$$$$
\text { IREMOB }=0 \text {. }
$$$$
\text { IWLVD }=0 \text {. }
$$$$
\text { IWLVG }=0 .
$$$$
\text { IWRTD }=0 .
$$$$
\text { IWRTG }=0 .
$$$$
\text { IWSTD }=0 .
$$$$
\text { IWSTG }=0 \text {. }
$$$$
\text { NUL }=0 \text {. }
$$$$
\text { REMOB }=0.0
$$

* Model parameters

* -----------------

YRNUM $=1$.

$\mathrm{AMX}=0.019$

CRIFAC $=0.0076$

$\mathrm{CVT}=1.05$

DAYEM $=1$.

DELAY $=7$.

$\mathrm{EE}=0.000011$

$\mathrm{HAR}=0$.

HARDAY $=304$.

HARDEP $=0.8$

NDTUB $=240$.

NINTUB $=8$.

$\mathrm{NPL}=30$.

$\mathrm{RC}=0.06$

RCSHST $=12.0$

RDTU $=0.026$

REDAM $=1$.

ROC $=0.0576$

RTR $=.19$

SURPER $=27$.

TBASE $=3$.

$\mathrm{TL}=0.1$

TWCTUB $=19.92$

* AFGEN functions

* AMDVST =

* 0.001, 1.,

* 1.243, 1.,

* 1.244, 0.6,

* 20.0, 0.6

AMTMPT = -30., 0.00001, $0 ., 0.00001$, 10., 0.027, 18., 0.51, 20., 0.53, 23., 0.71, 28., 0.91,
} 
30., 1.0,

50., 0.00001

DMPCT =

1.0, .043,

2.0, .043,

$3.0, .231$,

4.0, .254,

$5.0, .213$

DPTT $=$

1., 1.3,

365., 1.3

* DVRVT =

* -15., 0.,

* 0., 0.,

* 30.,0.015

* DVRRT =

* -15., 0.,

* 0., 0. ,

* 30.,0.040

FLT $=$

$0 ., 0.8$,

$3.5,0.8$,

20.0, 0.8

FLVT $=$

0., 0.731,

3.5, 0.731,

20.0, 0.731

FSTT =

0., 0.183,

$3.5,0.183$,

20.0, 0.183

FRTT =

0., 0.086,

3.5, 0.086,

20.0, 0.086

$\mathrm{KT}=$

0., 0.095,

3.5, 0.095,

20.0, 0.095

$\mathrm{LT}=$

1., 1.07,

365., 1.07

RDRT =

0., 0.047,

19., 0.047,

30., 0.094, 
* - The WEATHER control variables if weather data are used

* - Miscellaneous FSE variables in case of FSE translation

${ }^{*}$ File: POTAM.FOR

* Date: 09-08-97

* Time: 15:40:06

* TIMER variables used in GENERAL and FSE translation modes

$$
\text { * }
$$

$\begin{array}{lll}\text { STTIME } & =1 . & \text { ! start time } \\ \text { FINTIM } & =365 . & \text { ! finish time } \\ \text { DELT } & =1 . & \text { ! time step (for Runge-Kutta first guess) } \\ \text { PRDEL } & =1 . & \text { ! output time step } \\ \text { IPFORM } & =4 & \text { ! code for output table format: } \\ & \text { ! } 4 \text { = spaces between columns } \\ & \text { ! } 5 \text { = TAB's between columns (spreadsheet output) } \\ & \text { ! } 6=\text { two column output } \\ & \\ & \text { ! The string array PRSEL contains the output variables for which } \\ & \text { ! formatted tables have to be made. One or more times there is a } \\ & \text { ! The translator writes the variables in each PRINT statement to } \\ \text { PRSEL a separate table. }\end{array}$

* 'DAVTMP',

* 'DAYL ',

*'DDTMP',

* 'DTEFF',

* 'DTGA ',

* 'DVS ',

*'FGROS ',

*'GPHOT',

* 'IRS '

* 'MAINT ',

'NDTUB',

* 'NGTUB',

* 'NNTUB',

* 'NTM ',

* 'NTUBD ',

* 'NTUBPD',

* 'REMOB ',

* 'TEFF ',

'TGW ',

* 'TGWM' ',

* 'TMPSUM',

* 'TRANS ',

* 'TREMOB',

* 'TW ',

* 'TWGTUB',

* 'TWLVD ',

* 'TWLVG ',

* 'TWNTUB',

* 'TWRTD ',

'TWRTG ',

* 'TWSTD ',

* 'TWSTG ',

* 'TWTUB',

* 'TWTUBD', 


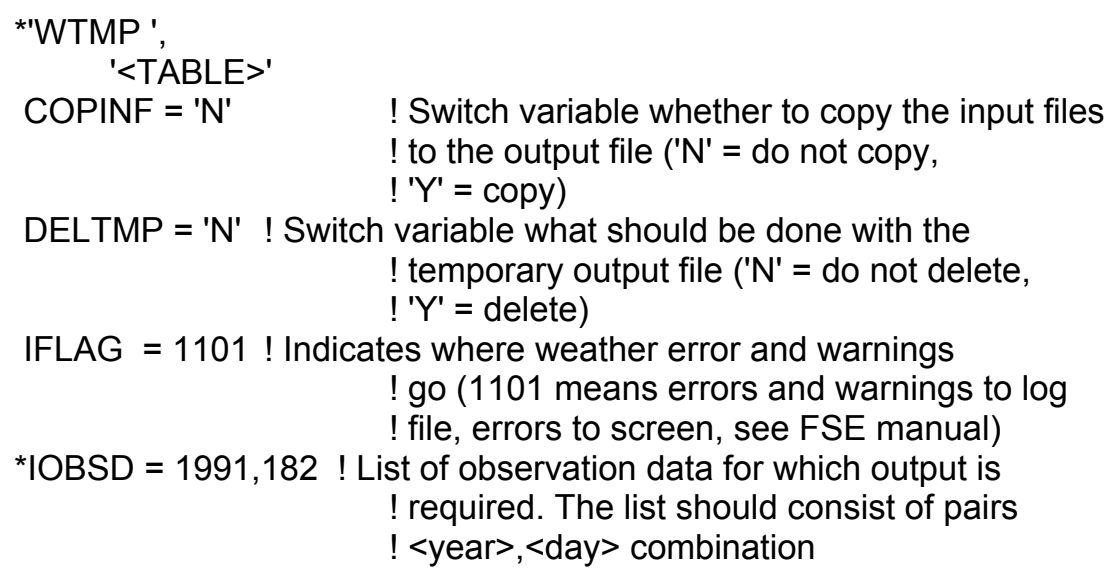

WEATHER control variables

$\begin{array}{lll}\text { WTRDIR } & =\text { 'C:ISYSIWEATHERI' } \\ \text { CNTR } & =\text { 'NLD' } & \text { ! Country code } \\ \text { ISTN } & =4 & \text { ! Station code } \\ \text { IYEAR } & =1978 & \text { ! Year }\end{array}$

*

* CONTROL.DAT file contains:

* File names to be used by FSE 2.1

* The input files (except FILEIR) may be used in reruns.

* Up to five input data files may be used (FILEI1-5)

$\begin{array}{ll}\text { FILEON = 'RES.DAT' } & \text { ! Normal output file } \\ \text { FILEOL = 'MODEL.LOG' } & \text { ! Log file } \\ \text { FILEIR = 'RERUNS.DAT' } & \text { ! Reruns file } \\ \text { FILEIT }=\text { 'TIMER.DAT' } & \text { ! File with timer data } \\ \text { FILEI1 }=\text { 'MODEL.DAT' } & \text { ! First input data file } \\ & \\ { }^{*} \text { FILEI2 }={ }^{*}, & \text { ! Second input data file (not used) } \\ { }^{*} \text { FILEI3 }={ }^{*} & \text { ! Third input data file (not used) } \\ { }^{*} \text { FILEI4 }={ }^{*} & \text { ! Fourth input data file (not used) } \\ { }^{*} \text { FILEI5 }={ }^{\prime} & \text { ! Fifth input data file (not used) }\end{array}$




\section{Appendix B Variable Listing}

\begin{tabular}{|c|c|c|}
\hline Abbreviation & Explanation & Dimension \\
\hline$\overline{\mathrm{AH}(\mathrm{i})}$ & $\begin{array}{l}\text { Absolute height of vegetation on top of stratum I, } \\
\text { measured from the plant top }\end{array}$ & $\mathrm{m}$ \\
\hline AMAX & $\begin{array}{l}\text { Actual } \mathrm{CO}_{2} \text { assimilation rate at light saturation for } \\
\text { individual shoots }\end{array}$ & $\mathrm{g} \mathrm{CO}_{2} \cdot g \mathrm{DW}^{-1} \cdot \mathrm{h}^{-1}$ \\
\hline AMTMP & Daytime temperature effect on AMX (relative) & - \\
\hline AMTMPT & Table of AMX as function of DVS & \\
\hline AMX & $\begin{array}{l}\text { Potential } \mathrm{CO}_{2} \text { assimilation rate at light saturation for shoot } \\
\text { tips }\end{array}$ & $\mathrm{g} \mathrm{CO}_{2} \cdot \mathrm{g} \mathrm{DW}^{-1} \cdot \mathrm{h}^{-1}$ \\
\hline ASRQ & Assimilate requirement for plant dry matter production & $\mathrm{g} \mathrm{CH}_{2} \mathrm{O} . \mathrm{g} \mathrm{DW}^{-1}$ \\
\hline ATMTR & Atmospheric transmission coefficient & - \\
\hline COSLD & Intermediate variable in calculating solar height & - \\
\hline CRIFAC & Critical weight per $0.1 \mathrm{~m}$ vegetation layer & $\begin{array}{l}\text { g DW per } \\
0.1 \mathrm{~m} \mathrm{plnt} \mathrm{ht}^{-1} . \mathrm{plnt}^{-1}\end{array}$ \\
\hline CRIGWT & Critical weight per $0.1 \mathrm{~m}$ vegetation layer & $\begin{array}{l}\text { g DW per } \\
0.1 \mathrm{~m}^{-1} \mathrm{nt} \mathrm{ht}^{-1} \cdot \mathrm{m}^{-2}\end{array}$ \\
\hline CVT & Conversion factor of translocated dry matter into $\mathrm{CH}_{2} \mathrm{O}$ & - \\
\hline DAVTMP & Daily average temperature & ${ }^{\circ} \mathrm{C}$ \\
\hline DAY & Day number (January $1=1$ ) & d \\
\hline DAYEM & First Julian day number & d \\
\hline DAYL & Day length & $\mathrm{h}$ \\
\hline DDELAY & Integer value of DELAY & - \\
\hline DDTMP & Daily average daytime temperature & ${ }^{\circ} \mathrm{C}$ \\
\hline DEC & Declination of the sun & radians \\
\hline DELAY & $\begin{array}{l}\text { Lag period chosen to relate water temperature to air temp., } \\
\text { in cases where water temp. has not been measured }\end{array}$ & d \\
\hline DEPTH & Water depth & $\mathrm{m}$ \\
\hline DLV & Death rate of leaves & $g D W \cdot m^{-2} \cdot d^{-1}$ \\
\hline DMPC(i) & Dry matter allocation to each plant layer (relative) & - \\
\hline DMPCT & Table to read DMPC(i) as function of depth layer (relative) & - \\
\hline DPTT & Table to read water depth as a function of day no & $m, d$ \\
\hline DRT & Death rate of roots & $g$ DW. $m^{-2} \cdot d^{-1}$ \\
\hline DSINB & Integral of SINB over the day & s.d $d^{-1}$ \\
\hline DSINBE & Daily total of effective solar height & s.d $d^{-1}$ \\
\hline DSO & Daily extra-terrestrial radiation & J.m $\mathrm{m}^{-2} \cdot \mathrm{d}^{-1}$ \\
\hline DST & Death rate of stems & g DW. $m^{-2} \cdot d^{-1}$ \\
\hline DTEFF & Daily effective temperature & ${ }^{\circ} \mathrm{C}$ \\
\hline DTGA & Daily total gross $\mathrm{CO}_{2}$ assimilation of the vegetation & $\mathrm{g} \mathrm{CO}_{2} \cdot \mathrm{m}^{-2} \cdot \mathrm{d}^{-1}$ \\
\hline DTR & Measured daily total global radiation & $\mathrm{J} \cdot \mathrm{m}^{-2} \cdot \mathrm{d}^{-1}$ \\
\hline DVR & Development rate as function of temperature sum & $d^{-1}$ \\
\hline
\end{tabular}




\begin{tabular}{|c|c|c|}
\hline DVRRT & $\begin{array}{l}\text { Table of post-anthesis development rate as function of } \\
\text { temperature sum (used for calibration; not read from } \\
\text { MODEL.DAT) }\end{array}$ & $\mathrm{d}^{-1},{ }^{\circ} \mathrm{C}$ \\
\hline DVRVT & $\begin{array}{l}\text { Table of pre-anthesis development rate as function of } \\
\text { temperature sum (used for calibration; not read from } \\
\text { MODEL.DAT) }\end{array}$ & $d^{-}, \mathrm{C}$ \\
\hline DVRVT & Development rate pre-anthesis & $d^{-1}$ \\
\hline DVS & Development phase of the plant & - \\
\hline EE & Initial light use efficiency for shoots & $\mathrm{gCO}_{2} \cdot \mathrm{J}^{-1}$ \\
\hline FGROS & Instantaneous $\mathrm{CO}_{2}$ assimilation rate of the vegetation & $\mathrm{g} \mathrm{CO}_{2} \cdot \mathrm{m}^{-2} \cdot \mathrm{h}^{-1}$ \\
\hline FGL & Instantaneous $\mathrm{CO}_{2}$ assimilation rate per vegetation layer & $\mathrm{g} \mathrm{CO}_{2} \cdot \mathrm{m}^{-2} \cdot \mathrm{h}^{-1}$ \\
\hline $\mathrm{FL}$ & Leaf dry matter allocation to each layer of shoot (relative)- & \\
\hline FLT & Table to read FL as function of DVS &,-- \\
\hline FLV & Fraction of total dry matter increase allocated to leaves & - \\
\hline FLVT & Table to read FLV as function of DVS & - \\
\hline FRDIF & Diffuse radiation as a fraction of total solar radiation & - \\
\hline FRT & Fraction of total dry matter increase allocated to roots & - \\
\hline FRTT & Table to read FRT as function of DVS &,-- \\
\hline FST & Fraction of total dry matter increase allocated to stems & - \\
\hline FSTT & Table to read FST as function of DVS &,-- \\
\hline GLV & Dry matter growth rate of leaves & g DW. $m^{-2} \cdot d^{-1}$ \\
\hline GPHOT & Daily total gross assimilation rate of the vegetation & $\mathrm{g} \mathrm{CH}_{2} \mathrm{O} \cdot \mathrm{m}^{-2} \cdot \mathrm{d}^{-1}$ \\
\hline GRT & Dry matter growth rate of roots & g DW. $m^{-2} \cdot d^{-1}$ \\
\hline GST & Dry matter growth rate of stems & $\mathrm{g} D W \cdot \mathrm{m}^{-2} \cdot \mathrm{d}^{-1}$ \\
\hline GTW & $\begin{array}{l}\text { Dry matter growth rate of the vegetation (plant excluding } \\
\text { tubers) }\end{array}$ & $\mathrm{g} D W \cdot \mathrm{m}^{-2} \cdot \mathrm{d}^{-1}$ \\
\hline HAR & Harvesting $(0=$ no harvesting, $1=$ harvesting $)$ & - \\
\hline HARDAY & Harvesting day number & d \\
\hline HARDEP & Harvesting depth (measured from water surface) & $\mathrm{m}$ \\
\hline$H I G(i)$ & Height on top of stratum I (measured from water surface) & $\mathrm{m}$ \\
\hline HOUR & Selected hour during the day & $\mathrm{h}$ \\
\hline I & Counter in DO LOOP - & \\
\hline IABS(i) & Total irradiance absorbed per depth layer & $\mathrm{J} \cdot \mathrm{m}^{-2} \cdot \mathrm{s}^{-1}$ \\
\hline IABSL(i) & Total irradiance absorbed per depth layer & $\mathrm{J} \cdot \mathrm{m}^{-2} \cdot \mathrm{s}^{-1}$ \\
\hline IDAY & Integer equivalent of variable DAY & d \\
\hline INTUB & Initial dry weight of a tuber & g DW.tuber ${ }^{-1}$ \\
\hline IREMOB & Initial value remobilization & $\mathrm{g} \mathrm{CH}_{2} \mathrm{O} \cdot \mathrm{m}^{-2}$ \\
\hline IRS & Total irradiance just under the water surface & J.m $\mathrm{m}^{-2} \cdot \mathrm{s}^{-1}$ \\
\hline IRZ(i) & Total irradiance on top of depth layer I & $\mathrm{J} \cdot \mathrm{m}^{-2} \cdot \mathrm{s}^{-1}$ \\
\hline IWLVDD & Initial dry matter of dead leaves & g DW. $\mathrm{m}^{-2}$ \\
\hline IWLVG & Initial dry matter of green (live) leaves & $\mathrm{g}$ DW. $\mathrm{m}^{-2}$ \\
\hline IWRTD & Initial dry matter of dead roots & g DW.m $\mathrm{m}^{-2}$ \\
\hline IWRTG & Initial dry matter of green (live) roots & g DW. $\mathrm{m}^{-2}$ \\
\hline IWSTD & Initial dry matter of dead stems & g DW. $\mathrm{m}^{-2}$ \\
\hline IWSTG & Initial dry matter of green (live) stems & g DW. $\mathrm{m}^{-2}$ \\
\hline & Plant species specific light extinction coefficient & $\mathrm{m}^{2} \cdot \mathrm{g} \mathrm{DW}^{-1}$ \\
\hline KCOUNT & $\begin{array}{l}\text { Counter used to calculate number of consecutive days in which } \\
\text { plantlets have a negative net photosynthesis }\end{array}$ & - \\
\hline KT & Table to read $\mathrm{K}$ as function of DVS & - \\
\hline & Water type specific light extinction coefficient & $m^{-1}$ \\
\hline LAT & Latitude of the site & degrees \\
\hline LT & Table to read $L$ as function of day number & $\mathrm{d}, \mathrm{m}^{-1}$ \\
\hline MAINT & Maintenance respiration rate of the vegetation & $\mathrm{g} \mathrm{CH}_{2} \mathrm{O} \cdot \mathrm{m}^{-2} \cdot \mathrm{d}^{-1}$ \\
\hline MAINTS & $\begin{array}{l}\text { Maintenance respiration rate of the vegetation at reference } \\
\text { temperature }\end{array}$ & $\mathrm{g} \mathrm{CH}_{2} \mathrm{O} \cdot \mathrm{m}^{-2} \cdot \mathrm{d}^{-1}$ \\
\hline NDTUB & Dormant tuber number & dormant tubers \\
\hline
\end{tabular}




\begin{tabular}{|c|c|c|}
\hline NGLV & Net growth rate of leaves & $g$ DW. $m^{-2} \cdot d^{-1}$ \\
\hline NGRT & Net growth rate of roots & g DW. $\mathrm{m}^{-2} \cdot \mathrm{d}^{-1}$ \\
\hline NGST & Net growth rate of stems & g DW. $m^{-2} \cdot d^{-1}$ \\
\hline NGTUB & Sprouting tuber number & spr. tubers. $\mathrm{m}^{-2}$ \\
\hline NINTUB & Tuber number concurrently initiated per plant & conc.in.tubers plnt $^{-1}$ \\
\hline NNTUB & New tuber number & new tubers.$m^{-2}$ \\
\hline NPL & Plant density & plants $\cdot m^{-2}$ \\
\hline NTM & Tuber density measured (field site) & tubers. $\mathrm{m}^{-2}$ \\
\hline NTMT & Table to read NTM as function of day number & tubers. $\mathrm{m}^{-2}, \mathrm{~d}$ \\
\hline NTUBD & Dead tuber number & dead tubers. $\mathrm{m}^{-2}$ \\
\hline NUL & Zero $(0)$ & - \\
\hline NTUBPD & Dead tuber number previous day & dead p.d.tubers. $\mathrm{m}^{-2}$ \\
\hline PAR & Instantaneous flux of photosynthetically active radiation & $J \cdot m^{-2} \cdot s^{-1}$ \\
\hline PARDIF & Instantaneous flux of diffuse PAR & $J \cdot m^{-2} \cdot s^{-1}$ \\
\hline PARDIR & Instantaneous flux of direct PAR & $J \cdot m^{-2} \cdot s^{-1}$ \\
\hline $\mathrm{PI}$ & Ratio of circumference to diameter of circle & - \\
\hline RAD & Factor to convert degrees to radians & radians.degree $^{-1}$ \\
\hline $\mathrm{RC}$ & Reflection coefficient of irradiance at water surface (relative) & - \\
\hline RCSHST & Relation coefficient tuber weight-stem length & $\mathrm{m}_{\mathrm{g}} \mathrm{g} \mathrm{DW} \mathrm{H}^{-1}$ \\
\hline RDR & Relative death rate of leaves (on DW basis) & $d^{-1}$ \\
\hline RDRT & Table to read RDR as function of DAVTMP & $\mathrm{d}^{-1},{ }^{\circ} \mathrm{C}$ \\
\hline RDS & Relative death rate of stems and roots (on DW basis) & $d^{-1}$ \\
\hline RDST & Table to read RDS as function of DAVTMP & $\mathrm{d}^{-1},{ }^{\circ} \mathrm{C}$ \\
\hline RDTU & Relative death rate of tubers (on number basis) & $d^{-1}$ \\
\hline REDAM & $\begin{array}{l}\text { Reduction factor to relate } \mathrm{AMX} \text { to } \mathrm{pH} \text { and oxygen levels of } \\
\text { the water (relative) }\end{array}$ & - \\
\hline REDF(i) & $\begin{array}{l}\text { Reduction factor for AMX to account for senescence plant } \\
\text { parts over vertical axis of vegetation (relative) }\end{array}$ & - \\
\hline REMOB & Remobilization rate of carbohydrates & g DW. $m^{-2} \cdot d^{-1}$ \\
\hline ROC & Relative conversion rate of tuber into plant material & $\mathrm{g} \mathrm{CH}_{2} \mathrm{O} . \mathrm{g} \mathrm{DW}^{-1} \cdot \mathrm{d}^{-1}$ \\
\hline RTR & Maximum relative tuber growth rate at $20^{\circ} \mathrm{C}$ & g DW.tuber ${ }^{-1} \cdot d^{-1}$ \\
\hline RTRL & Relative tuber growth rate at ambient temperature & g DW.tuber ${ }^{-1} \cdot d^{-1}$ \\
\hline SC & Solar constant corrected for varying distance sun-earth & $\mathrm{J} \cdot \mathrm{m}^{-2} \cdot \mathrm{s}^{-1}$ \\
\hline SC(i) & Shoot dry matter in depth layer $\mathrm{i}$ & g DW. $\mathrm{m}^{-2} \cdot$ layer $^{-1}$ \\
\hline SHTBIO & Shoot biomass; one term for sum WLV + WST & g DW. $\mathrm{m}^{-2}$ \\
\hline SINB & Sine of solar elevation & - \\
\hline SINLD & Intermediate variable in calculating solar declination & - \\
\hline STEMLE & Stem length & $\mathrm{m}$ \\
\hline SURFAC & $\begin{array}{l}\text { Expression of warning that plant canopy is not at water } \\
\text { and tuber class has died }\end{array}$ & - \\
\hline SSURPR & Integer value of SURPER & - \\
\hline SURPER & Survival period sprouting tubers & $\mathrm{d}$ \\
\hline TBASE & Base temperature for juvenile plant growth & ${ }^{\circ} \mathrm{C}$ \\
\hline TEFF & $\begin{array}{l}\text { Factor accounting for effect of temperature on maintenance } \\
\text { respiration, remobilization, relative tuber growth and death } \\
\text { rates }\end{array}$ & - \\
\hline TEFFT & $\begin{array}{l}\text { Table to read TEFF as function of temperature } \\
\left.\text { (Q10 of } 2 \text {, up to } 45^{\circ} \mathrm{C}\right)\end{array}$ &,$-{ }^{\circ} \mathrm{C}$ \\
\hline TGW & Total live plant dry weight (excluding tubers) & $\mathrm{g} \mathrm{DW} \cdot \mathrm{m}^{-2}$ \\
\hline TGWM & Total live plant dry weight measured (field site) & g DW.m $\mathrm{m}^{-2}$ \\
\hline TGWMT & Table to read TGWM as function of day number & g DW.m ${ }^{-2}, d$ \\
\hline TL & Thickness per depth layer & $\mathrm{m}$ \\
\hline TMAX & Daily maximum temperature & ${ }^{\circ} \mathrm{C}$ \\
\hline TMIN & Daily minimum temperature & ${ }^{\circ} \mathrm{C}$ \\
\hline TMPSUM & Temperature sum after 1 January & ${ }^{\circ} \mathrm{C}$ \\
\hline TRANS & Translocation rate of carbohydrates & $\mathrm{g} \mathrm{CH}_{2} \mathrm{O} \cdot \mathrm{m}^{-2} \cdot \mathrm{d}^{-1}$ \\
\hline
\end{tabular}


TREMOB Total remobilization

TW Total live + dead plant dry weight (excluding tubers)

g DW. $\mathrm{m}^{-2}$

TWCTUB Total critical dry weight of new tubers

g DW. $\mathrm{m}^{-2}$

TWGTUB Total dry weight of sprouting tubers

TWLVD Total dry weight of dead leaves

TWLVG Total dry weight of live leaves

TWNTUB Total dry weight of new tubers

TWRTD Total dry weight of dead roots

TWRTG Total dry weight of live roots

TWSTD Total dry weight of dead stems

TWSTG Total dry weight of live stems

TWTUB Total dry weight of tubers

WLV

WRT

WST

WTMP

Dry weight of leaves (live + dead)

Dry weight of roots (live + dead)

Dry weight of stems (live + dead)

Daily water temperature

WTMPT Table to read WTMP as function of day number

YRNUM

Year number simulation (1-5)

$\mathrm{g} D W \cdot \mathrm{m}^{-2}$

$\mathrm{g} D W \cdot \mathrm{m}^{-2}$

g DW. $m^{-2}$

g DW. $m^{-2}$

g DW. $m^{-2}$

$\mathrm{g} D W \cdot \mathrm{m}^{-2}$

g DW. $\mathrm{m}^{-2}$

$\mathrm{g} D W \cdot \mathrm{m}^{-2}$

g DW. $m^{-2}$

g DW. $\mathrm{m}^{-2}$

g DW.m.

g DW. $\mathrm{m}^{-2}$

g DW. $\mathrm{m}^{-2}$

${ }^{\circ} \mathrm{C}$

${ }^{\circ} \mathrm{C}, \mathrm{d}$

$y$ 


\section{Appendix C Manipulation of Literature Data Used for the Model Equations ${ }^{1}$}

\section{Introduction}

A 3-year study (1985-87) was conducted to determine the characteristics of biomass and photosynthetic activity of a sago pondweed population in The Netherlands. The collected data were meant to be used as a basis for the development of a dynamic numerical model to simulate the growth of sago pondweed populations in changing environmental and latitudinal conditions. The collected data have so far not been published, because of time constraints of the first author.

\section{Site Characteristics}

The site of study for the sago pondweed populations is located in the coastal Amsterdam Waterworks dune area near the village of Zandvoort, The Netherlands (longitude $05^{\circ} 11^{\prime} \mathrm{E}$, latitude $52^{\circ} 06^{\prime} \mathrm{N}$ ). Large amounts of surface water from the River Rhine (up to 150 million cubic meters year ${ }^{-1}$ ) are infiltrated in this part of the sandy dune area, recharged in infiltration canals, and recollected from a central basin, Oranjekom, for further treatment preceding the use for drinking water purposes. The infiltration canals, with depths up to $2.5 \mathrm{~m}$, host a large variety of aquatic plants. The current study has been carried out in the Western Canal part of the infiltration canal system (Table C1).

\footnotetext{
${ }^{1}$ Unpublished report entitled, "Biomass Characteristics and Photosynthetic Activity of Sago Pondweed Populations in the Western Canal Near Zandvoort, The Netherlands" by E. P. H. Best, F. H. H. Jacobs, and H. Van de Hagen 1987.
} 


\begin{tabular}{|c|c|}
\hline \multicolumn{2}{|c|}{$\begin{array}{l}\text { Table C1 } \\
\text { Properties of the Infiltration Canals in the Amsterdam Waterworks } \\
\text { Dune Area, The Netherlands, in } 1987 \\
\text { Water Quality Data, Mean Values }(N=25)\end{array}$} \\
\hline Property & Value \\
\hline \multicolumn{2}{|c|}{ All Canals } \\
\hline Total estimated length $(\mathrm{km})$ & 30 \\
\hline Width (m) & 35 \\
\hline Residence time $^{1}(\mathrm{~d})$ & $60-400$ \\
\hline Maximum depth $(m)$ & 2.5 \\
\hline \multicolumn{2}{|c|}{ Western Canal } \\
\hline Mean extinction coefficient $\left(\mathrm{m}^{-1}\right)$ & 1.07 \\
\hline$\overline{\mathrm{pH}}$ & $7.8-8.35$ \\
\hline Mean total alkalinity $\left(\mathrm{mg} \mathrm{L}^{-1}\right)$ & 182 \\
\hline Mean nitrate $\left(\mathrm{mg} \mathrm{L}^{-1}\right)$ & 6.30 \\
\hline Mean total-phosphate $\left(\mathrm{mg} \mathrm{L}^{-1}\right)$ & 0.112 \\
\hline
\end{tabular}

\section{Standing Crop}

Plant biomass of sago pondweed was estimated by harvesting three squares in the middle of a plant bed at regular intervals during 1987, using SCUBA. Each time, three 0.25 - by $0.25-\mathrm{m}$ squares were harvested. Four depth classes were studied, i.e., rooting at $0.5,1.0,1.5$ and $2.5 \mathrm{~m}$. All biomass samples were rinsed thoroughly and dried at $105{ }^{\circ} \mathrm{C}$ until constant weight. Ash was determined by combustion of the organic matter at $440{ }^{\circ} \mathrm{C}$. Biomass was expressed in $\mathrm{g}$ ash-free dry weight (AFDW) $\mathrm{m}^{-2}$. The data on the $1.0-\mathrm{m}$ rooting class were used for calibration of the POTAM model (Table C2).

\begin{tabular}{|c|c|c|c|c|}
\hline \multicolumn{5}{|c|}{$\begin{array}{l}\text { Table C2 } \\
\text { Standing Crop of Sago Pondweed in the Western Canal in 1987, } \\
\text { Mean Values }(\mathrm{N}=3)\end{array}$} \\
\hline \multirow[b]{2}{*}{ Day No. } & \multicolumn{4}{|c|}{ Plant Biomass, g AFDW m ${ }^{-2}$} \\
\hline & $0.5 \mathrm{~m}$ & $\overline{1.0 \mathrm{~m}}$ & $1.5 \mathrm{~m}$ & $2.5 \mathrm{~m}$ \\
\hline 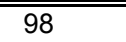 & 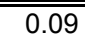 & 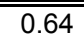 & 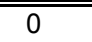 & 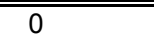 \\
\hline 134 & 0.22 & 8.00 & 4.02 & 0 \\
\hline 190 & 12.75 & 50.00 & 65.19 & \\
\hline 233 & 32.29 & 78.50 & 76.74 & 54.63 \\
\hline 260 & & 52.00 & & 82.27 \\
\hline 289 & 39.80 & 29.50 & 27.92 & 39.36 \\
\hline 294 & 0 & 18.8 & $\begin{array}{l}18.6 \\
\end{array}$ & 0 \\
\hline 304 & 0 & 0 & 0 & 0 \\
\hline
\end{tabular}




\section{Plant Biomass Distribution over the Water Column}

In the period when the vegetation reached peak biomass at the end of July 1987, five sago pondweed plants of the 1-m depth class were carefully excavated in such a way that the whole plants were kept intact. The plant samples were divided into $0.1-\mathrm{m}$ layers from top to bottom, and the fresh and dry weights of the plant portions were determined as described previously.

The collected data (Table C3) indicated that plant biomass was contained for 91.4 percent in shoots and for 8.6 percent in roots. Most plant biomass was concentrated for $>75$ percent (78.4) in the upper $0.5 \mathrm{~m}$ of the water column and followed a typical vertical distribution over the water column. The same trend of concentrating biomass in the upper $0.5 \mathrm{~m}$ of the water column was observed in the other depth classes.

\begin{tabular}{||l|l|l||}
\hline \hline \multirow{2}{||}{ Table C3 } \\
Plant Biomass Distribution over the Water Column of Sago \\
Pondweed in the Western Canal in July 1987, Mean Values (N=5)
\end{tabular}

\section{Species-characteristic Light Extinction Coefficient of Sago Pondweed}

The species-specific light extinction coefficient of sago pondweed was determined as follows. Light readings were taken just above the water surface, just below the water surface, and further at 0.10 -m intervals down the water column just outside and within a sago pondweed plant bed. The height of the vegetation within the water column was recorded, and five $0.04-\mathrm{m}^{2}$ vegetation squares were harvested. Samples were transported to the laboratory. The vegetation was cut into $0.10-\mathrm{m}$ sections from just above the sediment to the top of the vegetation, coded appropriately, and dried at $105^{\circ} \mathrm{C}$ for $24 \mathrm{hr}$ to constant mass. Dry weights were determined to the nearest $0.01 \mathrm{~g}$.

The light intensity at depth $h$ (in $\mathrm{m}$ ) from the upper surface of the plant community, designated by $I_{z+h}$ may be approximated by the following LambertBeer's law: 


$$
I_{z+h}=I_{z} \exp \left(-\varepsilon_{c} h\right)=I_{0} \exp \left(-\varepsilon_{s} z-\varepsilon_{c} h\right)
$$

in which

$I_{z}=$ the light intensity on a horizontal plane at the upper surface of the plant community $\left(\mu \mathrm{mol} \mathrm{m} \mathrm{m}^{-2}\right.$ )

$\varepsilon_{c}=$ the light extinction coefficient within the plant community $\left(\mathrm{m}^{-1}\right)$

$z=$ depth of the upper surface of the plant community, $\mathrm{m}$

$I_{0}=$ the light intensity passing through the water surface, approximated by the light intensity at $0.01-\mathrm{m}$ depth under the water surface $(\mu \mathrm{mol}$ $\mathrm{m}^{-2} \mathrm{~s}^{-1}$ )

$\varepsilon_{s}=$ the light extinction coefficient in the water outside the plant community $\left(\mathrm{m}^{-1}\right)$

The light extinction coefficient inside the plant community or $\varepsilon_{\mathrm{c}}$ represents the depth-dependent rate of light attenuation due to the absorption of light by both water and plant shoots. The light extinction coefficient due to the interception by shoots alone $\left(\varepsilon_{\mathrm{p}}\right.$ in $\left.\mathrm{m}^{2} \mathrm{~g}^{-1} \mathrm{DW}\right)$ was determined using the following equation

$$
\varepsilon_{p}=\left(\varepsilon_{c} h-\varepsilon_{s} h\right) / w(h)
$$

in which $w$ is the plant dry weight in $\mathrm{g} \mathrm{DW} \mathrm{m}^{-2}$.

The measured data used to calculate the shoot-specific light extinction coefficient for sago pondweed have been summarized in Table C4. In all cases similar values were found varying from 0.084 to $0.107 \mathrm{~m}^{2} \mathrm{~g}^{-1}$ AFDW . These values are far higher than reported by other investigators $\left(0.0183\right.$ to $0.020 \mathrm{~m}^{2} \mathrm{~g}^{-1}$

\begin{tabular}{|c|c|c|c|c|c|c|}
\hline \multicolumn{7}{|c|}{$\begin{array}{l}\text { Table C4 } \\
\text { Calculation of Species-Specific Light Extinction Coefficient for Potamogeton pectinatus } \\
\text { Growing in the Western Canal }\end{array}$} \\
\hline Replicate & $\begin{array}{l}l_{z} \\
\text { Water } \\
\text { Column } \\
\mu \mathrm{mol} \mathrm{m}^{-2} \mathrm{~s}^{-1}\end{array}$ & $\begin{array}{l}I_{z} \\
\text { Within Plant } \\
\text { Community } \\
\mu \mathrm{mol} \mathrm{m}^{-2} \mathrm{~s}^{-1} \\
\end{array}$ & $\begin{array}{l}\varepsilon_{\mathrm{s}} \text { Water } \\
\text { Water } \\
\text { Column } \\
\text { m }^{-1}\end{array}$ & $\begin{array}{l}\varepsilon_{\mathrm{c}} \text { Community } \\
\text { Water and Plant } \\
\text { Community } \\
\mathrm{m}^{-1} \\
\end{array}$ & $\begin{array}{l}\text { Cumulative Plant } \\
\text { Biomass } \\
\mathrm{g} \mathrm{DW} \mathrm{m}^{-2}\end{array}$ & $\begin{array}{l}\varepsilon \text { Plant } \\
\text { Plant } \\
\text { m }^{2} \text { g AFDW }^{-1}\end{array}$ \\
\hline \multicolumn{7}{|c|}{ Repl. 1} \\
\hline $0 \mathrm{~m}^{*}$ & 765 & 824 & & & 0 & \\
\hline $0.1 \mathrm{~m}$ & 731 & 735 & & & 0 & \\
\hline $0.2 \mathrm{~m}$ & 702 & 701 & & & 0 & \\
\hline $0.3 \mathrm{~m}$ & 708 & 523 & & & 1.84 & \\
\hline $0.4 \mathrm{~m}$ & 628 & 128 & & & 12.39 & \\
\hline $0.5 \mathrm{~m}$ & 606 & 40 & & & 26.48 & \\
\hline $0.6 \mathrm{~m}$ & 558 & 31 & 0.835 & 6.316 & 35.82 & 0.084 \\
\hline $0.7 \mathrm{~m}$ & 514 & & & & & \\
\hline $0.8 \mathrm{~m}$ & 478 & & & & & \\
\hline $0.9 \mathrm{~m}$ & 441 & & & & & \\
\hline \multicolumn{7}{|r|}{ (Continued) } \\
\hline
\end{tabular}
DW). 


\begin{tabular}{|c|c|c|c|c|c|c|}
\hline \multicolumn{7}{|c|}{ Table C4 (Concluded) } \\
\hline Replicate & $\begin{array}{l}I_{z} \\
\text { Water } \\
\text { Column } \\
\mu \mathrm{mol} \mathrm{m}{ }^{-2} \mathrm{~s}^{-1} \\
\end{array}$ & 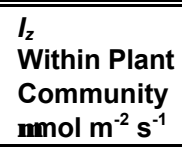 & $\begin{array}{l}\varepsilon_{\mathrm{s}} \text { Water } \\
\text { Water } \\
\text { Column } \\
\mathrm{m}^{-1} \\
\end{array}$ & $\begin{array}{l}\varepsilon_{\mathrm{c}} \text { Community } \\
\text { Water and Plant } \\
\text { Community } \\
\mathrm{m}^{-1} \\
\end{array}$ & $\begin{array}{l}\text { Cumulative Plant } \\
\text { Biomass } \\
\mathrm{g} \mathrm{DW} \mathrm{m}^{-2}\end{array}$ & $\begin{array}{l}\varepsilon \text { Plant } \\
\text { Plant } \\
\text { m }^{2} \text { g AFDW }^{-1}\end{array}$ \\
\hline \multicolumn{7}{|c|}{ Repl. 2} \\
\hline $0 \mathrm{~m}$ & 775 & 790 & & & & \\
\hline $0.1 \mathrm{~m}$ & 720 & 758 & & & & \\
\hline $0.2 \mathrm{~m}$ & 640 & 730 & & & & \\
\hline $0.3 \mathrm{~m}$ & 584 & 473 & & & 0.94 & \\
\hline $0.4 \mathrm{~m}$ & 555 & 90 & & & 6.96 & \\
\hline $0.5 \mathrm{~m}$ & 581 & 65 & & & 18.359 & \\
\hline $0.6 \mathrm{~m}$ & 458 & 21 & & & 28.97 & \\
\hline $0.7 \mathrm{~m}$ & 514 & 9 & 0.835 & 6.351 & 35.82 & 0.093 \\
\hline \multicolumn{7}{|c|}{ Repl. 3} \\
\hline \multicolumn{7}{|l|}{$0 \mathrm{~m}$} \\
\hline $0.1 \mathrm{~m}$ & & 790 & & & & \\
\hline $0.2 \mathrm{~m}$ & & 753 & & & & \\
\hline $0.3 \mathrm{~m}$ & & 670 & & & 0.94 & \\
\hline $0.4 \mathrm{~m}$ & & 382 & & & 6.96 & \\
\hline $0.5 \mathrm{~m}$ & & 310 & & & 18.35 & \\
\hline $0.6 \mathrm{~m}$ & & 126 & & & 28.97 & \\
\hline $0.7 \mathrm{~m}$ & & 35 & 0.835 & 6.166 & 35.82 & 0.107 \\
\hline $0.8 \mathrm{~m}$ & & 11 & & & & \\
\hline \multicolumn{7}{|c|}{ Repl. 4} \\
\hline $0 \mathrm{~m}$ & & 794 & & & & \\
\hline $0.1 \mathrm{~m}$ & & 744 & & & & \\
\hline $0.2 \mathrm{~m}$ & & 690 & & & & \\
\hline $0.3 \mathrm{~m}$ & & 615 & & & 1.84 & \\
\hline $0.4 \mathrm{~m}$ & & 530 & & & 12.39 & \\
\hline $0.5 \mathrm{~m}$ & & 172 & & & 26.48 & \\
\hline $0.6 \mathrm{~m}$ & & 140 & 0.835 & 4.618 & 35.82 & 0.088 \\
\hline $0.7 \mathrm{~m}$ & & 22 & & & & \\
\hline \multicolumn{7}{|c|}{ Repl. 5} \\
\hline $0 \mathrm{~m}$ & & 821 & & & 1.84 & \\
\hline $0.1 \mathrm{~m}$ & & 747 & & & 12.39 & \\
\hline $0.2 \mathrm{~m}$ & & 715 & & & 26.48 & \\
\hline $0.3 \mathrm{~m}$ & & 664 & 0.835 & 5.083 & 35.82 & 0.089 \\
\hline $0.4 \mathrm{~m}$ & & 221 & & & & \\
\hline $0.5 \mathrm{~m}$ & & 90 & & & & \\
\hline $0.6 \mathrm{~m}$ & & 66 & & & & \\
\hline $0.7 \mathrm{~m}$ & & 21 & & & & \\
\hline \multicolumn{7}{|c|}{ Repl. 6} \\
\hline $0 \mathrm{~m}$ & & 1030 & & & & \\
\hline $0.1 \mathrm{~m}$ & & 974 & & & & \\
\hline $0.2 \mathrm{~m}$ & & 892 & & & & \\
\hline $0.3 \mathrm{~m}$ & & 417 & & & & \\
\hline $0.4 \mathrm{~m}$ & & 613 & & & & \\
\hline $0.5 \mathrm{~m}$ & & 215 & & & & \\
\hline $0.6 \mathrm{~m}$ & & 90 & & & 3.34 & \\
\hline $0.7 \mathrm{~m}$ & & 56 & & & 22.33 & \\
\hline $0.8 \mathrm{~m}$ & & 1 & 0.835 & 4.222 & 35.82 & 0.107 \\
\hline Mean & & & & & & 0.095 \\
\hline
\end{tabular}




\section{Seasonal Changes in Maximum Photosynthetic Activity at Light Saturation}

\section{Plant material}

Sago pondweed tubers were collected in October 1987 in the Western Canal. These propagules were used to start a plant culture in 1.5-m-deep, 1-m-diameter, polyethylene containers, containing tap water and sediment from the Western Canal. The water was initially amended with bicarbonate up to $280 \mathrm{mg} \mathrm{HCO}_{3} \mathrm{~L}^{-1}$ as inorganic carbon source. The culture was kept on the grounds of the Centre for Agrobiological Research (CABO), in Wageningen, The Netherlands.

\section{Photosynthesis and respiration measurements}

At regular intervals during 1987-1988, whole plants and tubers were harvested from this culture to determine their photosynthetic and respiratory activities using the standard Infra Red Gas Analysis (IRGA) Facility of the CABO, Wageningen, The Netherlands. All gas exchange measurements were performed in 500-mL Perspex vessels, containing $200 \mathrm{~mL}$ M-medium amended with $280 \mathrm{mg} \mathrm{L}^{-1}$ bicarbonate (added as $\mathrm{NaHCO}_{3}$ ) and a $\mathrm{pH}$ of 7.0. Inflowing air was wetted prior to entering the vessels to prevent loss of medium during the incubation. Temperature was $20^{\circ} \mathrm{C}$, unless indicated otherwise. Each time individual plants were exposed successively to darkness and seven increasing light levels $\left(15,22,30,50,62.5,75\right.$ and 100 percent) up to $1121 \mu \mathrm{mol} \mathrm{m}^{-2} \mathrm{~s}^{-1}$ $\left(270 \mathrm{~W} \mathrm{~m}^{-2}\right)$, measured just under the lid of the vessel equipped with a photocell). Successive light levels were changed when photosynthetic activity had stabilized. Light was provided by Philips $400 \mathrm{~W}$ HPIT metal halide lamps, and light levels were changed by changing the distance between lamp and vessel. Total duration of each incubation was usually 6-8 hr. Incubations were replicated four times. Before incubation, the plants were rinsed carefully with tap water to remove loosely attached periphyton, and their fresh weights were recorded. After incubation, dry weight, ash content, and the concentrations of starch and soluble sugars were determined.

\section{Maximum Photosynthetic Rate at Light and $\mathrm{CO}_{2}$ Saturation, and at Air Levels of $\mathrm{CO}_{2}$}

Maximum photosynthetic rates were far higher at light and $\mathrm{CO}_{2}$ saturation than at air levels of $\mathrm{CO}_{2}$ (Table C5). 


\begin{tabular}{|c|c|c|c|c|}
\hline \multicolumn{5}{|c|}{$\begin{array}{l}\text { Table C5 } \\
\text { Maximum Photosynthetic Rates of Sago Pondweed Plants } \\
\text { Incubated under Standard Laboratory Conditions, Using IRGA }\end{array}$} \\
\hline \multirow[b]{3}{*}{$\begin{array}{l}\text { Day } \\
\text { No. }\end{array}$} & \multicolumn{4}{|c|}{ Maximum Photosynthetic Rate at Light Saturation } \\
\hline & \multicolumn{2}{|c|}{$\mathrm{CO}_{2}$-saturated (this study) } & \multicolumn{2}{|c|}{$\begin{array}{c}\text { Air Levels of } \mathrm{CO}_{2} \text { (Van der Bijl et al. } \\
1989)\end{array}$} \\
\hline & $\begin{array}{l}\text { Absolute } \\
\mathrm{g} \mathrm{CO}_{2} \mathrm{~g} \mathrm{DW}^{-1} \mathrm{~h}^{-1}\end{array}$ & $\begin{array}{l}\text { Relative (percent } \\
\text { highest value) } \\
\end{array}$ & $\begin{array}{l}\text { Absolute } \\
\mathrm{g} \mathrm{O}_{2} \mathrm{~g} \mathrm{DW}^{-1} \mathrm{~h}^{-1} \\
\end{array}$ & $\begin{array}{l}\text { Relative (percent } \\
\text { highest value) } \\
\end{array}$ \\
\hline 130 & & & 0.002 & 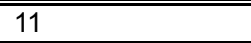 \\
\hline 135 & & & 0.007 & 48 \\
\hline 141 & & & 0.014 & 100 \\
\hline 146 & 0.039 & 100 & & \\
\hline 156 & & & 0.013 & 93 \\
\hline 162 & & & 0.009 & 65 \\
\hline 178 & 0.028 & 73 & & \\
\hline 194 & 0.012 & 31 & & \\
\hline 209 & 0.023 & 58 & & \\
\hline 217 & & & 0.008 & 56 \\
\hline 225 & 0.021 & 54 & & \\
\hline 227 & & & 0.008 & 59 \\
\hline 244 & & & 0.008 & 59 \\
\hline 250 & 0.025 & 65 & & \\
\hline 274 & & & 0.006 & 44 \\
\hline 278 & & & 0.005 & 37 \\
\hline 287 & 0.034 & 89 & & \\
\hline 291 & & & 0.003 & 24 \\
\hline 294 & 0.025 & 64 & & \\
\hline 329 & 0.019 & 50 & & \\
\hline \multicolumn{5}{|c|}{$\begin{array}{l}\text { Note: Plants originated from a culture started from tubers harvested from the } 1-\mathrm{m} \text { depth class in the } \\
\text { Western Canal. Mean values and } \mathrm{SD}(\mathrm{N}=4) \text {. For comparison photosynthetic rates of sago } \\
\text { pondweed measured in the field (freshwater River Susa, Denmark) using the oxygen exchange } \\
\text { method are given. }\end{array}$} \\
\hline
\end{tabular}

\section{Effect of Daytime Temperature on Photosynthesis (AMTMP)}

To calibrate the relationship between temperature and photosynthetic activity, the photosynthetic rates relative to the rate at $30{ }^{\circ} \mathrm{C}$ found by the authors of this appendix (Table C6) were used. The very low values of 0.00001 have not been measured, but were assigned to photosynthetic activity at 0 and $50{ }^{\circ} \mathrm{C}$.

\section{Growth}

The value of the conversion factor for growth of leaf biomass, weighted according to its composition, can be computed in a simple way from the fractions of nonstructural carbohydrates, proteins, fats, cellulose, organic acids, and minerals (Table C7). This conversion factor indicates the amount of glucose consumed to produce each $\mathrm{g}$ of leaf biomass $\left(\mathrm{g} \mathrm{CH}_{2} \mathrm{O} \mathrm{g} \mathrm{DW}^{-1}\right)$. This method has been employed to calculate assimilate requirements for biomass production of sago pondweed leaves. 


\begin{tabular}{|l|l|l||}
\hline \multirow{2}{|l|}{$\begin{array}{l}\text { Table C6 } \\
\text { Relative Photosynthetic Activity of Sago Pondweed Shoots in } \\
\text { Response to Temperature as Used for Calibration of the Model }\end{array}$} \\
\hline \hline \multirow{2}{*}{ Temperature, ${ }^{\circ} \mathbf{C}$} & \multicolumn{2}{|c|}{ Photosynthetic Rate } \\
\cline { 2 - 3 } & Absolute, $\mathbf{g ~ C O}_{\mathbf{2}} \mathbf{g}$ DW $\mathbf{~ h}^{-1}$ & Relative to Highest Value \\
\hline \hline 0 & & 0.00001 \\
\hline 10 & 0.00440 & 0.027 \\
\hline 18 & 0.00844 & 0.51 \\
\hline 20 & 0.00881 & 0.53 \\
\hline 23 & 0.01174 & 0.71 \\
\hline 28 & 0.01505 & 0.91 \\
\hline 30 & 0.01652 & 1.000 \\
\hline 50 & & 0.00001 \\
\hline
\end{tabular}

\begin{tabular}{||l||}
\hline \hline \multicolumn{3}{||}{ Table C7 } \\
Estimated Chemical Composition of Sago Pondweed Shoots (this \\
study), and Typical Conversion Efficiencies for Agricultural Crops, \\
Showing How Much Glucose Is Used for the Synthesis of Each \\
Organic Matter Component (Penning de Vries and Van Laar 1982b)
\end{tabular}

\section{Tuber Characteristics: Size, Carbohydrate Reserves, and Respiratory Activity}

Size, carbohydrate reserves, and respiratory activity were determined in the sago pondweed tubers collected in October and subsequently kept in culture at the $\mathrm{CABO}$ grounds. Starch was measured in perchloric acid extracts of the plant material according to Hewitt (1958). ${ }^{1}$ The soluble sugars were determined in hot water extracts using enzymatic techniques (Bergmeyer 1970). All determinations were done in triplicate. A detailed description of the latter procedure is given by Best and Visser (1987).

The average tuber size was $0.083 \pm 0.012 \mathrm{~g} \mathrm{DW} \mathrm{tuber}^{-1}(\mathrm{~N}=12)$. The concentrations of starch ranged from 33.1 to 53.2 percent and those of soluble

\footnotetext{
${ }^{1}$ References cited in this appendix are listed in the References section at the end of the main text.
} 
sugars from 9.4 to 17.0 percent dry weight (Table C8). The respiratory activity, monitored on average over a period of $40 \mathrm{hr}$ to allow respiration to reach steady state, was $0.003623 \pm 0.0003 \mathrm{~g} \mathrm{CO}_{2} \mathrm{~g} \mathrm{DW}^{-1} \mathrm{~h}^{-1}$ at $20{ }^{\circ} \mathrm{C}(\mathrm{N}=12)$.

\begin{tabular}{|c|c|c|}
\hline \multicolumn{3}{|c|}{$\begin{array}{l}\text { Table C8 } \\
\text { Carbohydrate Reserves in Sago Pondweed Tubers Harvested in } \\
\text { Autumn } 1987 \text { from the 1-m Depth Class in the Western Canal Mean } \\
\text { values and SD }(\mathrm{N}=3)\end{array}$} \\
\hline Day No. & "Starch, \% AFDW & Soluble Sugars \% AFDW \\
\hline 82 & $33.1 \pm 0$ & $177.0 \pm 0.5$ \\
\hline 285 & $38.8 \pm 13.6$ & $9.4 \pm 1.1$ \\
\hline 331 & $53.2 \pm 2.1$ & $14.8 \pm 0.7$ \\
\hline 346 & $46.1 \pm 0.8$ & $6.9 \pm 0.3$ \\
\hline
\end{tabular}

\section{Site-specific Environmental Conditions}

$\mathrm{pH}$, alkalinity, and trophic state are important factors influencing primary production in aquatic systems. $\mathrm{pH}$ and alkalinity determine carbon availability for photosynthesis, and trophic state gives an indication of algal production and consequent light attenuation within the water column. The model is calibrated for dissolved inorganic carbon concentrations around $2.5 \mathrm{mmol}$ (Table $\mathrm{C} 1$ ).

$\mathrm{pH}$ affecting potential photosynthetic rate at light saturation through REDAM can be modified by the user.

The model is calibrated for a light-extinction coefficient range of the water of 0.82 to $1.974 \mathrm{~m}^{-1}$ (mean 1.07, Table C9); the value of this parameter (L) can be modified by the user.

\section{Water Temperature}

The temperature has been measured in the surface water of the Western Canal at several points in time in 1987 (Table C9). For days 1 and 365 the same temperatures as those measured on the nearest dates have been taken.

Temperatures in all other canals were similar, but slightly higher in the Eastern Canal. 


\begin{tabular}{|c|c|c|}
\hline \multicolumn{3}{|c|}{$\begin{array}{l}\text { Table C9 } \\
\text { Seasonally Measured Daytime Temperatures in the Surface Water } \\
\text { of the Western Canal during } 1987\end{array}$} \\
\hline Day No. & Temperature, ${ }^{\circ} \mathrm{C}$ & Light Extinction Coefficient, $\mathrm{m}^{-1}$ \\
\hline 7 & 5.5 & 0.845 \\
\hline 14 & Ice & \\
\hline 28 & 7.5 & 1.196 \\
\hline 35 & 6.5 & 0.907 \\
\hline 42 & 7.5 & \\
\hline 49 & 6.0 & \\
\hline 57 & 7.0 & 1.632 \\
\hline 63 & 4.5 & 1.022 \\
\hline 68 & 5.0 & 1.165 \\
\hline 77 & 7.5 & 1.123 \\
\hline 84 & 10.0 & 1.236 \\
\hline 91 & 9.5 & 1.046 \\
\hline 99 & 10.5 & 1.037 \\
\hline 105 & 8.0 & 0.928 \\
\hline 112 & 13.0 & 1.291 \\
\hline 119 & 14.0 & 0.817 \\
\hline 133 & 10.5 & 1.217 \\
\hline 140 & 12.0 & 1.401 \\
\hline 147 & 15.0 & 1.703 \\
\hline 155 & 14.0 & 1.022 \\
\hline 162 & 11.5 & 0.981 \\
\hline 169 & 13.0 & 0.830 \\
\hline 175 & 14.0 & 0.828 \\
\hline 183 & 16.0 & 0.821 \\
\hline 202 & & 1.157 \\
\hline 210 & 14.0 & 1.974 \\
\hline 217 & 14.5 & 0.805 \\
\hline 224 & 16.5 & 0.993 \\
\hline 232 & 17.0 & 1.340 \\
\hline 238 & 14.0 & 0.988 \\
\hline 245 & 15.0 & 0.912 \\
\hline 252 & 14.5 & 0.959 \\
\hline 260 & 14.0 & 0.960 \\
\hline 266 & 15.5 & 0.899 \\
\hline 273 & 13.0 & 0.907 \\
\hline 281 & 12.5 & 0.939 \\
\hline 287 & 12.0 & 0.898 \\
\hline 295 & 12.0 & 1.066 \\
\hline 301 & 12.0 & 0.902 \\
\hline 309 & 11.0 & 0.824 \\
\hline 315 & 10.0 & 1.089 \\
\hline
\end{tabular}




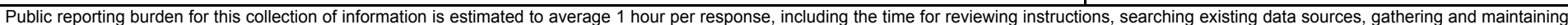

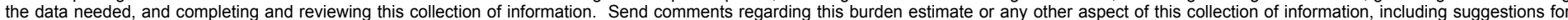

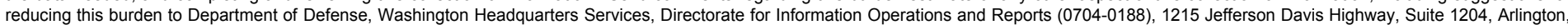

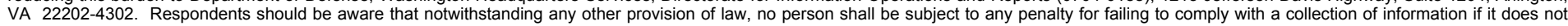
display a currently valid OMB control number. PLEASE DO NOT RETURN YOUR FORM TO THE ABOVE ADDRESS.

\begin{tabular}{l|c}
$\begin{array}{l}\text { 1. REPORT DATE (DD-MM-YYYY) } \\
\text { July } 2003\end{array}$ & $\begin{array}{c}\text { 2. REPORT TYPE } \\
\text { Final report }\end{array}$ \\
\hline
\end{tabular}

\section{TITLE AND SUBTITLE}

A Simulation Model for Growth of the Submersed Aquatic Macrophyte Sago Pondweed (Potamogeton pectinatus L.)

3. DATES COVERED (From - To)

5a. CONTRACT NUMBER

5b. GRANT NUMBER

5c. PROGRAM ELEMENT NUMBER

\section{AUTHOR(S)}

Elly P. H. Best, William A. Boyd

\section{5d. PROJECT NUMBER}

5e. TASK NUMBER

5f. WORK UNIT NUMBER

33128

8. PERFORMING ORGANIZATION REPORT NUMBER

ERDC/EL TR-03-6

U.S. Army Engineer Research and Development Center

Environmental Laboratory

3909 Halls Ferry Road

Vicksburg, MS 39180-6199

9. SPONSORING / MONITORING AGENCY NAME(S) AND ADDRESS(ES)

U.S. Army Corps of Engineers

Washington, DC 20314-1000

10. SPONSOR/MONITOR'S ACRONYM(S)

11. SPONSOR/MONITOR'S REPORT NUMBER(S)

\section{DISTRIBUTION / AVAILABILITY STATEMENT}

Approved for public release; distribution is unlimited.

\section{SUPPLEMENTARY NOTES}

\section{ABSTRACT}

A simulation model for biomass dynamics of the submersed macrophyte Potamogeton pectinatus L. is presented. The model (POTAM) is based on carbon flow through the vegetation in meter-squared $\left(\mathrm{m}^{2}\right)$ water columns. It includes descriptions of several factors that affect biomass dynamics, such as site characteristic changes in climate, temperature, water transparency, water level, $\mathrm{pH}$, and oxygen effects on $\mathrm{CO}_{2}$ assimilation rate at light saturation, wintering strategies, mechanical control (removal of shoot biomass), and grazing. The characteristics of community and site can be easily modified by the user.

POTAM incorporates insight into the processes affecting the dynamics of a sago pondweed community in relatively shallow, hard water (0.1- to 6-m depth; dissolved inorganic carbon concentration $>0.8 \mathrm{mmol}$ and $\mathrm{pH}>6$ ), under ample supply of nitrogen and phosphorus in a pest-, disease-, and competitor-free environment under the prevailing weather conditions. It has been calibrated on data pertaining to a sago pondweed community in the Western Canal near Zandvoort, The Netherlands. At this site, growth starts from the subterranean tubers alone. Plant biomass usually peaks once a year, in July, and intensive downward transport of soluble carbohydrates occurs after anthesis, used for the formation of tubers that grow into the sediment.

(Continued)

\section{SUBJECT TERMS}

Biomass dynamics

Carbon flow

16. SECURITY CLASSIFICATION OF:

\section{a. REPORT}

UNCLASSIFIED

b. ABSTRACT
UNCLASSIFIED

Plant growth

Potamogeton pectinatus

Simulation model

\begin{tabular}{|c|c|c|}
\hline & $\begin{array}{l}\text { 17. LIMITATION } \\
\text { OF ABSTRACT }\end{array}$ & $\begin{array}{l}\text { 18. NUMBER } \\
\text { OF PAGES }\end{array}$ \\
\hline $\begin{array}{l}\text { c. THIS PAGE } \\
\text { UNCLASSIFIED }\end{array}$ & & 117 \\
\hline
\end{tabular}

19a. NAME OF RESPONSIBLE PERSON

19b. TELEPHONE NUMBER (include area code) 


\section{ABSTRACT (continued)}

POTAM simulated the dynamics of plant and tuber biomass and tuber numbers in the Western Canal near Zandvoort, The Netherlands, well over a period of 1 to 5 years. Starting from measured instead of nominal tuber size increased the similarity between simulated and measured plant data. The importance of several plant speciescharacteristic properties was explored, namely, of leaf surface:dry weight ratio, tuber bank density, anchorage depth, and presence/absence of wintering shoots.

The model has been used to calculate plant and tuber biomass and tuber numbers for other sites as well. In Lake Veluwe, The Netherlands, a site with a temperate climate, simulated plant biomass and newly produced tuber densities were similar to measured ones in two consecutive years, but timing in the simulated plants was delayed the second year. In the Byrnes Canal, California, with a far warmer temperate climate, simulated plant biomass and tuber bank density were similar to measured values when a lower self-shading coefficient than the nominal one and the same tuber size/tuber number per plant as measured were used. However, plant biomass and tuber bank density were lower with the nominal self-shading coefficient. In the tropical Lake Ramgarh, India, a simulated peak plant biomass similar to measured was found using the same lower self-shading coefficient as run for the California site, and almost no tubers were formed. Verification of simulated with measured tuber numbers was not possible, since tubers had not been measured.

Several case studies are presented in which POTAM generated insight useful for management aimed at conserving or controlling sago pondweed populations. The model was used to calculate the tentative effects on sago pondweed populations of (a) water level fluctuations, including floods and droughts, in the Upper Mississippi River; and (b) plant and tuber mass removal by cutting or grazing.

Sensitivity analysis showed that maximum plant biomass is most sensitive to a change in photosynthetic activity at light saturation but not to a change in light use efficiency. Maximum plant biomass was also strongly affected by changes in pre-anthesis development rate. End-of-year tuber number was sensitive to 7 out of the 9 parameters tested. Sensitivity was greatest to changes in pre-anthesis development rate.

Effects of changes in environmental factors were analyzed by applying the same method as used for sensitivity analysis. Maximum plant biomass and end-of-year tuber number proved to be sensitive to changes in climate.

The model can be used as a tool to predict the dynamics of a sago pondweed community over 1- to 5-year periods. Running the model with different parameter values specific for any particular site and/or treatment helps in gaining insight into the predominant mechanisms regulating submersed plant dynamics. 